\title{
Structure-Activity Relationships of Benzothiazole-Based Hsp90 C-Terminal-Domain Inhibitors
}

\author{
Jaka Dernovšek, Živa Zajec, Martina Durcik (1), Lucija Peterlin Mašič, Martina Gobec, Nace Zidar (1) \\ and Tihomir Tomašič * (D)
}

check for

updates

Citation: Dernovšek, J.; Zajec, Ž.; Durcik, M.; Mašič, L.P.; Gobec, M.;

Zidar, N.; Tomašič, T.

Structure-Activity Relationships of

Benzothiazole-Based Hsp90

C-Terminal-Domain Inhibitors.

Pharmaceutics 2021, 13, 1283.

https://doi.org/10.3390/

pharmaceutics13081283

Academic Editors: David Ramírez and Ana Martínez

Received: 26 July 2021

Accepted: 13 August 2021

Published: 17 August 2021

Publisher's Note: MDPI stays neutral with regard to jurisdictional claims in published maps and institutional affiliations.

Copyright: (c) 2021 by the authors. Licensee MDPI, Basel, Switzerland. This article is an open access article distributed under the terms and conditions of the Creative Commons Attribution (CC BY) license (https:// creativecommons.org/licenses/by/ $4.0 /)$.
Faculty of Pharmacy, University of Ljubljana, Aškerčeva Cesta 7, 1000 Ljubljana, Slovenia; jaka.dernovsek@ffa.uni-lj.si (J.D.); ziva.zajec@ffa.uni-lj.si (Ž.Z.); martina.durcik@ffa.uni-lj.si (M.D.); lucija.peterlinmasic@ffa.uni-lj.si (L.P.M.); martina.gobec@ffa.uni-lj.si (M.G.); nace.zidar@ffa.uni-lj.si (N.Z.)

* Correspondence: tihomir.tomasic@ffa.uni-lj.si

\begin{abstract}
Heat shock protein 90 (Hsp90) is a chaperone responsible for the maturation of many cancer-related proteins, and is therefore an important target for the design of new anticancer agents. Several Hsp90 N-terminal domain inhibitors have been evaluated in clinical trials, but none have been approved as cancer therapies. This is partly due to induction of the heat shock response, which can be avoided using Hsp90 C-terminal-domain (CTD) inhibition. Several structural features have been shown to be useful in the design of Hsp90 CTD inhibitors, including an aromatic ring, a cationic center and the benzothiazole moiety. This study established a previously unknown link between these structural motifs. Using ligand-based design methodologies and structure-based pharmacophore models, a library of 29 benzothiazole-based Hsp90 CTD inhibitors was prepared, and their antiproliferative activities were evaluated in MCF-7 breast cancer cells. Several showed low-micromolar $\mathrm{IC}_{50}$, with the most potent being compounds $5 \mathrm{~g}$ and $9 \mathrm{i}\left(\mathrm{IC}_{50}, 2.8 \pm 0.1,3.9 \pm 0.1 \mu \mathrm{M}\right.$, respectively). Based on these results, a ligand-based structure-activity relationship model was built, and molecular dynamics simulation was performed to elaborate the binding mode of compound $\mathbf{9 i}$. Moreover, compound 9i showed degradation of Hsp90 client proteins and no induction of the heat shock response.
\end{abstract}

Keywords: allosteric; Hsp90; benzothiazole; cancer; inhibitor; cancer therapy

\section{Introduction}

Heat shock protein 90 (Hsp90) is a chaperone that consists of four highly conserved isoforms: inducible Hsp90 $\alpha$ and constitutively expressed Hsp90 $\beta$ (both localized in the cytosol), mitochondrial TRAP-1, and Grp94 (localized in the endoplasmic reticulum) [1-3]. To carry out their functions, all four Hsp90 isoforms are obligate homodimers [3]. Each monomeric unit of Hsp90 consists of an ATP-hydrolyzing N-terminal domain (NTD), which is connected via a charged linker to the middle domain and C-terminal domain (CTD) $[2,4,5]$. This last is responsible for dimerization [5,6], and it forms a secondary nucleotide binding pocket without ATPase activity. This secondary binding site only becomes available upon the binding of ATP to the NTD $[7,8]$.

Together with its co-chaperones, Hsp90 is responsible for ensuring proteostasis, by guaranteeing correct protein folding and maturation, along with preventing aggregation of its client proteins $[5,9,10]$. In a healthy human cell, Hsp90 represents $1 \%$ to $2 \%$ of all the protein, making it one of the most abundant cellular proteins [11]. Although Hsp90 is vital for the functionality of more than 400 proteins [12,13], its abundance still provides a functional reserve and allows cells to function even when Hsp90 is downregulated [14].

Furthermore, the expression of Hsp90 is increased in various cancers due to the stress conditions and oxygen deprivation in the tumor environment [13,15]. Therefore, although mutations in Hsp90 itself are scarce [13], this chaperone is involved in all 10 hallmarks of cancer [6,12]. The protein clients of Hsp90 include protein kinases (e.g., Akt, Cdk4), 
transcription factors (e.g., p53, Hif1), E3 ubiquitin ligases, and steroid hormone receptors, all of which are essential for cancer pathogenesis [2,16]. Under malignant transformation, the oncogenic Hsp90 client proteins become even more dependent on Hsp90 to maintain a suitable conformation for their function [17]. Consequently, Hsp90 has been intensively studied for the development of anticancer agents since the early 1990s [13,18-20].

Since the discovery of the first Hsp90 NTD inhibitor geldanamycin in 1994 [19], at least 18 Hsp90 inhibitors that target the NTD have entered clinical trials. Unfortunately, none of these have been successful to date [13,21], due to various toxicities and strong activation of the heat shock response (HSR) [13]. The HSR is particularly problematic because the upregulation of different heat shock proteins that are controlled by heat shock factor 1 (HSF1) leads to cytoprotective effects, thus counteracting any treatment effects [13,21-23]. Therefore, investigations have shifted toward the development of NTD isoform-selective inhibitors [12], protein-protein interaction inhibitors [24], and CTD allosteric modulators of Hsp90 [12,25], which do not induce the HSR.

The first Hsp90 CTD inhibitor discovered was the coumarin antibiotic novobiocin [26], which was originally developed as a bacterial DNA gyrase inhibitor [27]. All of the subsequent ligands have contributed to the definition of the structure-activity relationships (SARs) necessary for Hsp90 CTD inhibition. Many of the resulting compounds (e.g., see Figure 1) have highlighted the importance of the cationic center at a sufficient distance from the aromatic ring, while the linker is important for molecular rigidity and provides an opportunity for hydrogen bond formation with the Hsp90 CTD [28-32]. From a series of novobiocin core analogs, a distance from $7.7 \AA$ to $12.1 \AA$ between the $N$-methylpiperidine and the biaryl side chain was shown to be optimal for Hsp90 CTD inhibition [33].
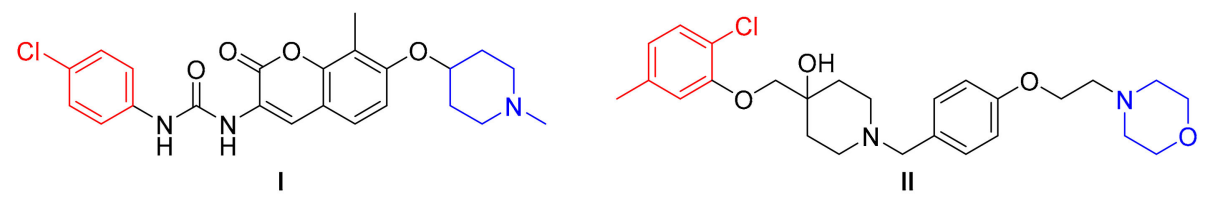

Figure 1. Two known Hsp90 C-terminal-domain inhibitors, (I) and (II), that feature a cationic center and aromatic ring at the opposite ends of their structures [30,32].

Although the Hsp90 CTD is characterized by X-ray crystallography and cryo-electron microscopy, the allosteric binding site has not been specified. Therefore, the exact binding mode of Hsp90 CTD inhibitors remains challenging to determine. Nevertheless, a structure-based study using the cryo-electron microscopy structure of Hsp90 $\beta$ confirmed the importance of the basic center and the aromatic ring at the appropriate distance [32]. On the other hand, the benzothiazole has been shown to be a useful structural feature for Hsp90 inhibitors [34] that target the CTD [35]. However, no connections between the CTD SARs and the benzothiazole ring as a central scaffold have been established to date.

Therefore, we conducted this SAR study using computational and biological methods of evaluation to investigate benzothiazole-based Hsp90 inhibitors that also feature characteristic structural properties of other CTD inhibitors.

\section{Materials and Methods}

\subsection{Synthetic Procedures and Analytical Data}

Reagents and solvents for synthesis were purchased from Enamine Ltd. (Kyiv, Ukraine), Apollo Scientific Ltd. (Stockport, UK), Sigma-Aldrich (St. Louis, MO, USA), TCI (Tokyo, Japan), and Fluorochem Ltd. (Derbyshire, UK), and were not further purified. Analytical thin-layer chromatography was performed on silica gel aluminum sheets $(0.20 \mathrm{~mm} ; 60$ F254; Merck, Darmstadt, Germany). Column chromatography was performed using silica gel 60 (particle size, $230-400$ mesh). ${ }^{1} \mathrm{H},{ }^{13} \mathrm{C}$ and ${ }^{19} \mathrm{~F}$ NMR spectra were recorded on a $400 \mathrm{MHz}$ NMR spectrometer (Bruker Advance 3, Bruker, Billerica, MA, USA). The splitting patterns were designated as follows: $\mathrm{s}$, singlet; $\mathrm{d}$, doublet; $\mathrm{dd}$, double doublet; $\mathrm{td}$, triple doublet; $\mathrm{t}$, triplet; $\mathrm{dt}$, double triplet; $\mathrm{ddd}$, double of doublet of doublet; $\mathrm{q}$, quartet; $\mathrm{p}$, pentet; 
and $\mathrm{m}$, multiplet. The purities of the prepared compounds were monitored by liquid chromatography-mass spectrometry that was performed using method A (see below) on a 1260 Infinity II LC system (Agilent Technologies, Santa Clara, CA, USA), which was equipped with a quaternary pump and a wavelength detector. The system was coupled to the mass spectrometry (Expression CMS ${ }^{\mathrm{L}}$; Advion Inc., Ithaca, NY, USA). The high-resolution mass spectra (HRMS) (Exactive Plus Orbitrap mass spectrometer; Thermo Scientific Inc., Waltham, MA, USA) used optical rotation detection at $\lambda=589 \mathrm{~nm}$ (Polarimeter Model 241; Perkin Elmer, Boston, MA, USA).

Method A: A C18 column was used (Waters xBridge BEH; $4.6 \mathrm{~mm} \times 150 \mathrm{~mm}, 3.5 \mu \mathrm{m}$ ) at $40{ }^{\circ} \mathrm{C}$. The flow rate was of the mobile phase was $1.5 \mathrm{~mL} / \mathrm{min}$, the injection volume was $10 \mu \mathrm{L}$, and the products were detected at $254 \mathrm{~nm}$. Solvent A comprised $1 \% \mathrm{CH}_{3} \mathrm{CN}$ and $0.1 \% \mathrm{HCOOH}$ in double-distilled $\mathrm{H}_{2} \mathrm{O}$; Solvent $\mathrm{B}$ comprised $\mathrm{CH}_{3} \mathrm{CN}$. The following elution gradient was used: $0 \rightarrow 1 \mathrm{~min}, 25 \% \mathrm{~B} ; 1 \rightarrow 6 \mathrm{~min}, 25 \% \rightarrow 98 \% \mathrm{~B} ; 6 \rightarrow 6.5 \mathrm{~min}, 98 \% \mathrm{~B}$; $6.5 \rightarrow 7 \mathrm{~min}, 98 \% \rightarrow 25 \% \mathrm{~B} ; 7 \rightarrow 10 \mathrm{~min}, 25 \% \mathrm{~B}$.

Detailed chemical synthesis procedures and chemical analysis results of all intermediates and final compounds $5 \mathbf{a}-\mathbf{m}, \mathbf{8 k}-\mathbf{n}, \mathbf{9 a}-\mathbf{j}, \mathbf{1 0}$ and $\mathbf{1 4}$ are described in Appendix A and Supplementary Materials.

\subsection{Docking}

The software FRED (OEDOCKING 3.3.0.2: OpenEye Scientific Software, Santa Fe, NM, USA, http: / / www.eyesopen.com, accessed on 1 July 2021) [36,37] was used for docking experiments at the Hsp90 $\beta$ CTD binding site [32] (PDB entry: 5FWK) [38]. The binding site for docking experiments was created using MAKE RECEPTOR (Release 3.2.0.2, OpenEye Scientific Software, Inc., Santa Fe, NM, USA; www.eyesopen.com, accessed on 1 July 2021). The grid box with the following dimensions: $21.67 \AA \times 24.67 \AA \times 16.00 \AA$ and the volume of $8551 \AA^{3}$ was automatically generated around the coumarin-based Hsp90 CTD inhibitor and was not adjusted. The "Molecular" method was used for "Cavity detection", and the outer and inner contours were automatically calculated with the "Balanced" settings. The inner contours were disabled. A library of a maximum of 200 conformations per ligand was created using OMEGA (Release 3.3.1.2, OpenEye Scientific Software, Inc., Santa Fe, NM, USA; www.eyesopen.com, accessed on 1 July 2021). The library of ligand conformers was then rigidly docked to the prepared Hsp90 CTD binding site using FRED (default settings). Docking poses were scored and ranked using Chemgauss 4 scoring function. The results were visualized and analyzed with VIDA (version 4.3.0.4, OpenEye Scientific Software, Inc., Santa Fe, NM, USA, www.eyesopen.com, accessed on 1 July 2021).

\subsection{Molecular Dynamics Simulations}

MD simulations of the Hsp90-9i complex were performed using NAMD package (version 2.9) [39] and the CHARMM22 force field [40,41]. The ParamChem tool [42-44] was used to estimate the molecular mechanics parameters for compound $9 \mathbf{i}$. Removal of potential steric clashes and optimization of the atomic coordinates of the Hsp903-9i docking complex were first performed by steepest descent and adopted basis Newton-Raphson energy minimizations (10,000 steps each). The structure of the Hsp90-9i complex embedded in a box of TIP3P water molecules and neutralized by the addition of $\mathrm{NaCl}$ was prepared using psfgen in VMD (version 1.9.1) [45]. The MD simulation was carried out in the NPT ensemble using the periodic boundary conditions. The Langevin dynamics and Langevin piston methods were used for temperature $(300 \mathrm{~K})$ and pressure $(1 \mathrm{~atm})$ control, respectively. Short-range and long-range forces were calculated every 1 and 2 time steps, respectively, with a time step of 2.0 ps. The smooth particle mesh Ewald method [46] was used to calculate the electrostatic interactions. The short-range interactions were cut off at $12 \AA$. All of the chemical bonds between hydrogen and the heavy atoms were held fixed, using the SHAKE algorithm [47]. The simulation consisted of three consecutive steps: (i) solvent equilibration for $1 \mathrm{~ns}$ with ligand and protein constrained harmonically around the initial structure; (ii) equilibration of the complete system for $1 \mathrm{~ns}$ with ligand 
and protein released; and (iii) an unconstrained 500 ns production run. For structure-based pharmacophore modeling, 2500 frames from the production run were saved separately and used for interaction analysis.

\subsection{Structure-Based Pharmacophore Modeling}

The 500 ns MD trajectory of Hsp90 $\beta$ dimer (PDB Entry: 5FWK) [38] in complex with compound $9 \mathbf{i}$ was used for chemical feature interaction analysis, using LigandScout 4.4 Expert [48], which resulted in 2500 structure-based pharmacophore models.

\subsection{MTS Assay}

The compounds were evaluated for their antiproliferative activities against the MCF-7 (ATCC HTB-22, adherent cells isolated form 69 years old white female) breast cancer cell line, using an MTS (Promega, Madison, WI, USA) assay, according to the manufacturer's instructions. The MCF-7 cell line was obtained from American Type Culture Collection (ATCC, Manassas, VA, USA). The cells were cultured in Dubecco's modified Eagle's medium (Sigma-Aldrich, St. Louis, MO, USA), which was supplemented with $10 \%$ fetal bovine serum (Gibco, Thermo Fisher Scientific, Waltham, MA, USA), $100 \mathrm{U} / \mathrm{mL}$ penicillin (Sigma-Aldrich, St. Louis, MO, USA), $100 \mu \mathrm{g} / \mathrm{mL}$ streptomycin (Sigma-Aldrich, St. Louis, MO, USA), and $2 \mathrm{mM}$ L-glutamine (Sigma-Aldrich, St. Louis, MO, USA). MCF-7 cells were incubated in a $5 \% \mathrm{CO}_{2}$ atmosphere at $37^{\circ} \mathrm{C}$. The cells were plated in 96-well plates at a density of 2000 cells per well. Afterwards, the cells were incubated for $24 \mathrm{~h}$, and then treated with the final compounds, positive control $(1 \mu \mathrm{M}$ 17-DMAG) or vehicle control (0.5\% DMSO). After the $72 \mathrm{~h}$ incubation, CellTiter96 Aqueous One Solution Reagent $(10 \mu \mathrm{L}$; Promega, Madison, WI, USA) was added to each well, and the cells were incubated for an additional $3 \mathrm{~h}$. Then the absorbance was measured using a microplate reader (Synergy 4 Hybrid; BioTek, Winooski, VT, USA). Independent experiments were repeated two times, each performed in triplicate. The statistically significant differences $(p<0.05)$ were calculated between the treated groups and DMSO, using two-tailed Welch's $t$-tests. The $\mathrm{IC}_{50}$ values were determined using GraphPad Prism 8.0 software (San Diego, CA, USA), and represent the concentration at which a compound produced a half-maximal response; these are given as means from the independent measurements.

\subsection{Western Blotting of MCF-7 Cells}

MCF-7 cells were cultured as previously described. The cells were treated with $10 \mu \mathrm{M}$ and $1 \mu \mathrm{M}$ compound 9i, $0.5 \mu \mathrm{M}$ 17-DMAG (positive control) and 0.5\% DMSO (vehicle) and incubated for $24 \mathrm{~h}$. After these incubations, the cells were rinsed with $1 \times$ DPBS (Gibco, Thermo Fisher Scientific, Waltham, MA, USA) and then lysed with RIPA buffer ( $50 \mathrm{mM}$ Tris- $\mathrm{HCl}, \mathrm{pH} 7.4,150 \mathrm{mM} \mathrm{NaCl}, 1 \% \mathrm{NP}-40,0.5 \%$ sodium deoxycholate, $1 \mathrm{mM}$ EDTA), containing 1:100 Halt protease inhibitor cocktail (Thermo Fisher Scientific, Waltham, MA, USA) and 1:100 Halt phosphatase inhibitor cocktail (Thermo Fisher Scientific, Waltham, MA, USA). Cell lysates were sonicated and then centrifuged at 15,000 rpm for $20 \mathrm{~min}$ at $4{ }^{\circ} \mathrm{C}$. The supernatants were collected, and the protein concentrations were determined using the DC protein assay (Bio-Rad, Hercules, CA, USA). Equal amounts of protein $(30 \mu \mathrm{g})$ were separated, using SDS PAGE (10\% acrylamide/bisacrylamide gels,), electrophoresed at $80 \mathrm{~V}$ for $15 \mathrm{~min}$, then at $130 \mathrm{~V}$ for $60 \mathrm{~min}$, and then transferred onto nitrocellulose membranes using a dry blotting system (iBlot 2; Thermo Fisher Scientific, Waltham, MA, USA). Nonspecific binding sites were blocked in 5\% bovine serum albumin for $1 \mathrm{~h}$ at room temperature, prior to exposure to the primary antibody solutions. Membranes were incubated with the primary antibodies overnight at $4{ }^{\circ} \mathrm{C}$, and then with the secondary antibodies for $1 \mathrm{~h}$ at room temperature. The primary antibodies used in these experiments included anti-Hsp90 rabbit mAb (1:1000, Cell Signaling, Danvers, MA, USA), Hsp70 Mouse mAb (1:1000, Cell Signaling, Danvers, MA, USA), anti-c-Raf rabbit mAb (1:1000, Cell Signaling, Danvers, MA, USA), anti-Akt rabbit mAb (1:1000, Cell Signaling, Danvers, MA, USA), anti-estrogen receptor $\alpha$ mAb mouse (1:1000, Santa Cruz Biotechnology, Dallas, TX, 
USA). $\beta$-Actin Mouse mAb (1:5000, Sigma-Aldrich, St. Louis, MO, USA). The secondary antibodies used was an anti-IgG, Hrp-linked rabbit antibody $(1: 10,000$, Cell Signaling, Danvers, MA, USA) and anti-IgG, Hrp-linked mouse antibody (1:10,000 Cell Signaling, Danvers, MA, USA). Blots were visualized, using UVITEC Cambridge Imaging System (UVITEC, Cambridge, UK).

\section{Results and Discussion}

\subsection{Design}

In the absence of a co-crystal structure of Hsp90 CTD in complex with a CTD inhibitor, we used a ligand-based design methodology (Figure 2) supported by structure-based pharmacophore models (SBPMs) derived from molecular dynamics (MD) simulations from our previous study [32]. Our aim was to prepare a focused library of benzothiazolebased Hsp90 CTD inhibitors, and to establish the SARs for their Hsp90 inhibition. The benzothiazole moiety was selected as a suitable central scaffold that offers the possibility for the attachment of aromatic substituents and basic amines to positions 2 and 6, which are characteristic for Hsp90 CTD inhibitors (Figure 1). In contrast to the already known benzothiazoles A and B (Figure 2) [34,35], we decided to introduce aromatic groups at position 6 of the benzothiazole moiety and to replace the amide bond at position 2 with an amine directly linked to the benzothiazole ring (Figure 2). This amine would serve as an attachment point for the various linkers to the basic center. Furthermore, a different orientation of the amide bond was introduced at position 6, in contrast to the already known inhibitors [34,35].

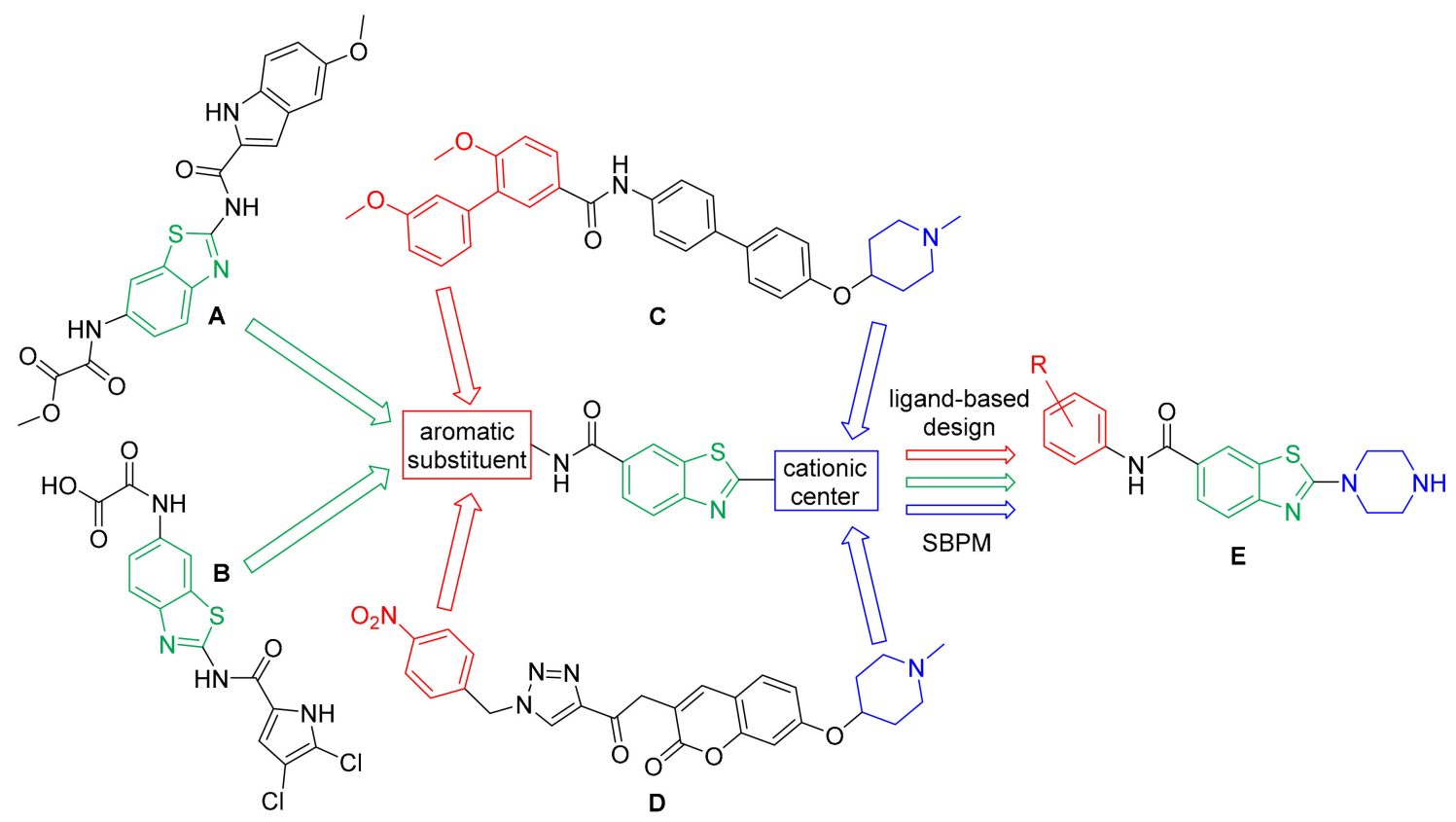

Figure 2. The design strategy started with the known benzothiazole-based Hsp90 C-terminal-domain (CTD) inhibitors A [35] and B [34]. These were combined with the well-established general structure-activity relationships of Hsp90 CTD inhibitors represented by compounds $\mathbf{C}$ [29] and D [28]. A new compound of class $\mathbf{E}$ was also designed and included.

To confirm this design strategy, the library of benzothiazoles designed using the strategy shown in Figure 2 was screened against the SBPMs (Figure 3) derived from the MD simulation of a coumarin-based Hsp90 CTD inhibitor in complex with Hsp90ß [32]. This pharmacophore model shown in Figure 3 consisted of two hydrophobic features (yellow spheres): one with an aromatic ring feature on one side (blue disc) and a positive ionizable feature on the opposite side (blue star). For screening, these features were marked as essential, while the hydrogen bond donor feature (Figure 3, green arrow) was marked as optional. This last feature is coumarin-ring-specific and not critical for Hsp90 CTD 
inhibition. Screening was performed for a small library of compounds with the general structure of $\mathbf{E}$ (Figure 2) and with different substituents on the phenyl ring as $\mathrm{R}$ (i.e., $\mathrm{H}, 3-\mathrm{Cl}$, 4-Cl, 3-OH, 4-OH). This identified compounds with $\mathrm{R}$ as 3-Cl (Figure 3, compound 5b) or 4-Cl as promising candidates for Hsp90 CTD inhibition, as they provided a good fit to the model.

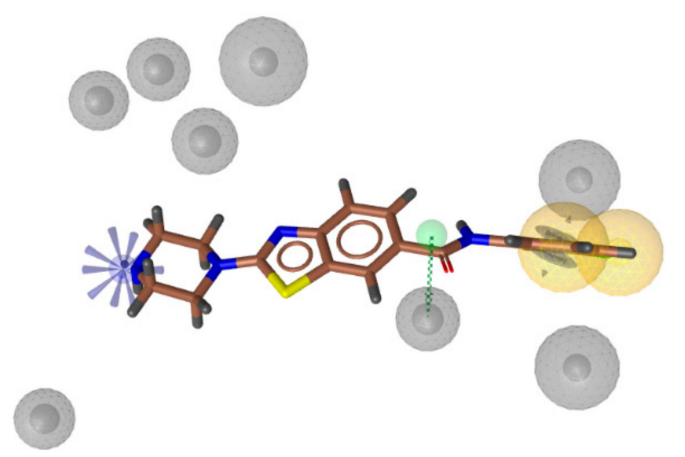

Figure 3. Alignment of a representative compound $(\mathrm{R}, 3-\mathrm{Cl})$ of the general structure $\mathrm{E}$ (brown sticks) with the three-dimensional structure-based pharmacophore model derived from molecular dynamics simulation of a coumarin-based Hsp90 CTD inhibitor in complex with Hsp90 [32]. The pharmacophores included two with hydrophobic features (yellow spheres), one with an aromatic (blue disc), a hydrogen bond (H-bond) donor (green arrow, indicating the defined direction for $\mathrm{H}$ bonding), and a positive ionizable (blue star). The exclusion volumes (grey spheres) define restricted regions based on the shape of the aligned molecules.

From the alignment in Figure 3, it can be seen that further optimization of the distance between the aromatic ring and the basic center was possible. Together with the variation in the phenyl ring substituents, this might provide improved interactions within the binding pocket, and thus we synthesized a focused library of new Hsp90 CTD inhibitors following the design strategy shown in Figure 2.

\subsection{Synthesis}

To evaluate the impact of the phenyl ring substitutions and variations on the inhibitory activity, compounds $5 \mathbf{a}-\mathbf{m}$ were synthesized as shown in Scheme 1 . In the first step, a Sandmeyer reaction was performed to generate the 2-bromo derivative $\mathbf{1}$, followed by nucleophilic aromatic substitution with 1-Boc protected piperazine, to yield compound 2 . Next, the ethyl ester was hydrolyzed with $1 \mathrm{M} \mathrm{NaOH}$ to produce carboxylic acid 3 . In the penultimate step, an aromatic ring was introduced at position 6 through amide coupling, using 1-ethyl-3-(3-dimethylaminopropyl)carbodiimide (EDC) and hydroxybenzotriazole (HOBt) as coupling reagents, to prepare compounds $\mathbf{4 a - m}$. The final compounds $\mathbf{5} \mathbf{a}-\mathbf{m}$ were synthesized by acidolysis of $\mathbf{4 a - m}$, using trifluoroacetic acid in dichloromethane (DCM).

To investigate the SARs at position 2 of the benzothiazole core (Scheme 2), 2-aminobenzo [d]thiazole-6-carboxylic acid was used as the starting point for the synthesis. First, 4-chloroaniline was coupled to the carboxylic acid at position 6 of the benzothiazole to provide 6. Subsequently, a Sandmeyer reaction was carried out to substitute the aromatic amine at position 2 with bromine (7). Aromatic nucleophilic substitution was then used to introduce various amines at position 2 of the benzothiazole to generate the final compounds without cationic centers, $\mathbf{8 k} \mathbf{- n}$. This reaction was also used to prepare compounds $\mathbf{8} \mathbf{a}-\mathbf{j}$ with Boc protected amines, which were then Boc-deprotected by acidolysis to synthesize the final products $9 \mathbf{a}-\mathbf{j}$. 


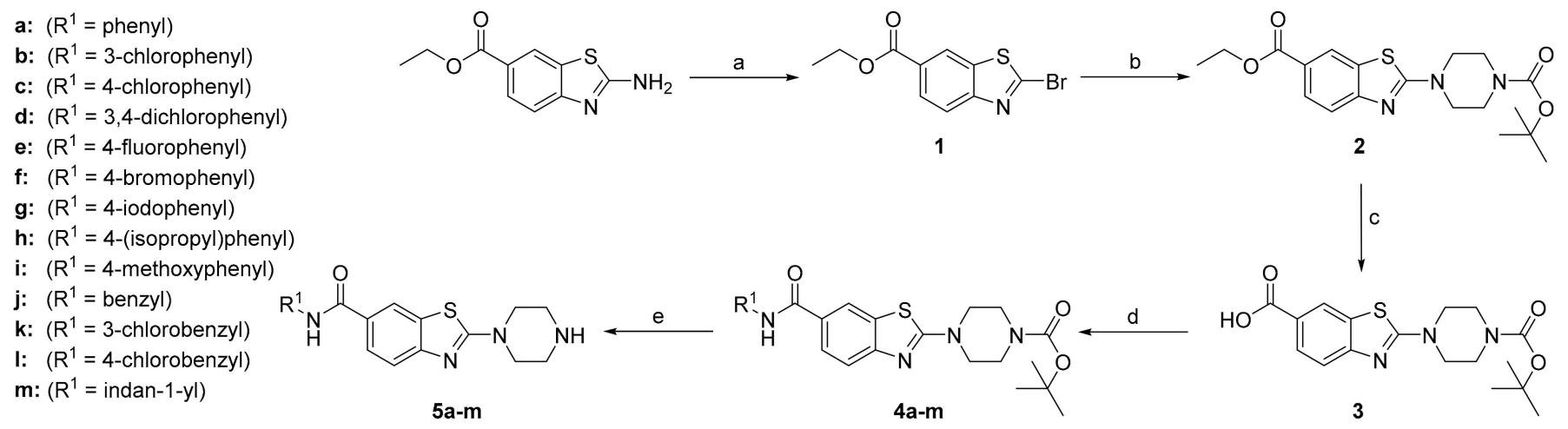

Scheme 1. Reagents and conditions: (a) $\mathrm{CuBr}_{2}, t$-BuONO, $\mathrm{MeCN}, 0{ }^{\circ} \mathrm{C}$ to r.t., 2 h; (b) 1-Boc-piperazine, $\mathrm{THF}$, r.t., overnight; (c) $1 \mathrm{M} \mathrm{NaOH}, 96 \% \mathrm{EtOH}, 100{ }^{\circ} \mathrm{C}, 2 \mathrm{~h}$; (d) (i) EDC, HOBt, DIPEA, DMF, r.t. 20 min; (ii) respective amine, 1-3 days; (e) $\mathrm{CF}_{3} \mathrm{COOH}, \mathrm{DCM}$, r.t., $1-3$ days.

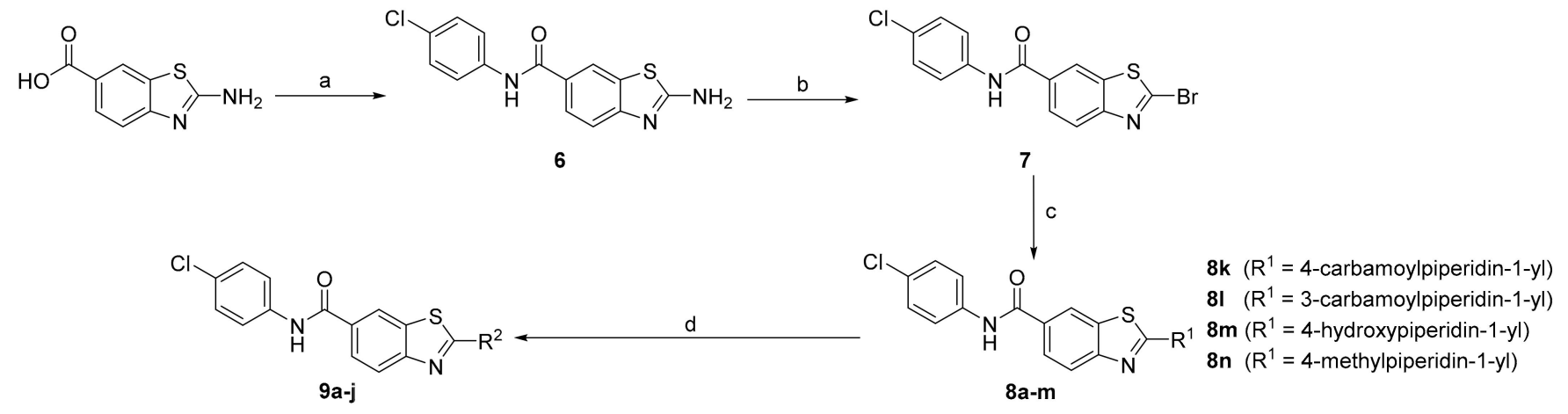

9a $\left(R^{2}=(3\right.$-aminopropyl)amino

9b $\left(R^{2}=3\right.$-aminopiperidin-1-yl)

9c $\left(R^{2}=3-(S)\right.$-aminopyrrolidin-1-yl)

9d $\left(\mathrm{R}^{2}=3-(R)\right.$-aminopyrrolidin-1-yl)

9e $\left(R^{2}=4\right.$-aminomethylpiperidn-1-yl)

9f $\left(R^{2}=\right.$ piperidin-4-ylamino

$9 g\left(R^{2}=2,7\right.$-diazaspiro[4.4]nonan-7-yl)

9h $\left(R^{2}=\right.$ hexahydropyrrolo[3,4-c]pyrrol-5-yl)

9i $\left(R^{2}=4\right.$-aminopiperidin-1-yl)

9j $\left(R^{2}=4-[N\right.$-methyl-amino]piperidin-1-yl) 8a $\left(R^{1}=(3-(B o c-a m i n o)\right.$ propyl)amino

$\mathbf{8 b}\left(\mathrm{R}^{1}=3-[N-B o c-a m i n o] p i p e r i d i n-1-y l\right)$

$8 \mathrm{c}\left(\mathrm{R}^{1}=3-(S)-[N-\right.$ Boc-amino]pyrrolidin-1-yl $)$

8d $\left(\mathrm{R}^{1}=3-(R)-[N\right.$-Boc-amino]pyrrolidin-1-yl)

$8 \mathrm{e}\left(\mathrm{R}^{1}=4-[N\right.$-Boc-aminomethyl] piperidn-1-yl)

$8 f\left(R^{1}=(1-B o c-p i p e r i d i n-4-y l) a m i n o\right.$

$8 g\left(R^{1}=2-B o c-2,7-d i a z a s p i r o[4.4]\right.$ nonan-7-yl)

8h $\left(R^{1}=2-B o c-h e x a h y d r o p y r r o l o[3,4-c] p y r r o l-5-y l\right)$

$8 \mathrm{i} \quad\left(\mathrm{R}^{1}=4-[N\right.$-Boc-amino]piperidin-1-yl)

8j $\left(R^{1}=4-[N-B o c-N\right.$-methyl-amino]piperidin-1-yl)

Scheme 2. Reagents and conditions: (a) (i) EDC, HOBt, DIPEA, DMF, r.t. 20 min; (ii) 4-chloroaniline, r.t., overnight; (b) $\mathrm{CuBr}_{2}, t-\mathrm{BuONO}, \mathrm{MeCN}, 0{ }^{\circ} \mathrm{C}$ to r.t., overnight; (c) respective amine, $\mathrm{Et}_{3} \mathrm{~N}$, $\mathrm{THF}$, r.t., overnight; (d) $\mathrm{CF}_{3} \mathrm{COOH} \mathrm{DCM}$, r.t., 1-3 days.

To further establish the SARs, two additional analogs of compound 9i were prepared as well as the monomethylated analog $\mathbf{9 j}$. From $\mathbf{9 j}$, a dimethylated analog $\mathbf{1 0}$ was synthesized using reductive amination, as shown in Scheme 3. Compound $\mathbf{1 4}$ was synthesized from compound 1 as shown in Scheme 3. First the 4-(N-Boc-amino)piperidine was introduced at position 2 of the benzothiazole ring to generate compound 11. Then, the ester was hydrolyzed to prepare compound 12, to which the 3,4-dichloroaniline was introduced using amide coupling, to generate compound 13. Ultimately, the Boc protection group was removed by acidolysis to yield the final compound 14 . 

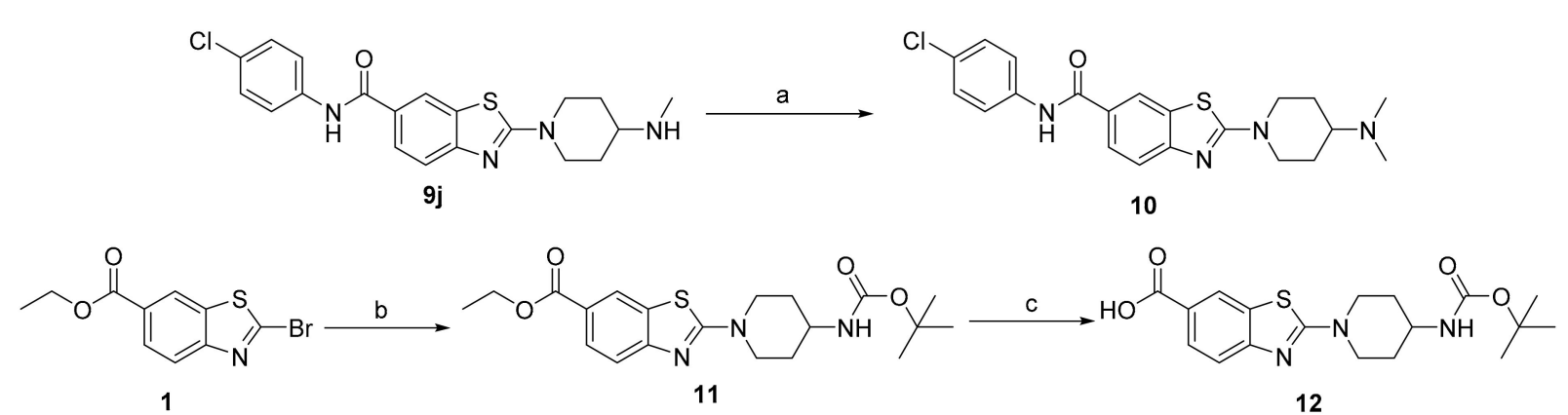

1

11
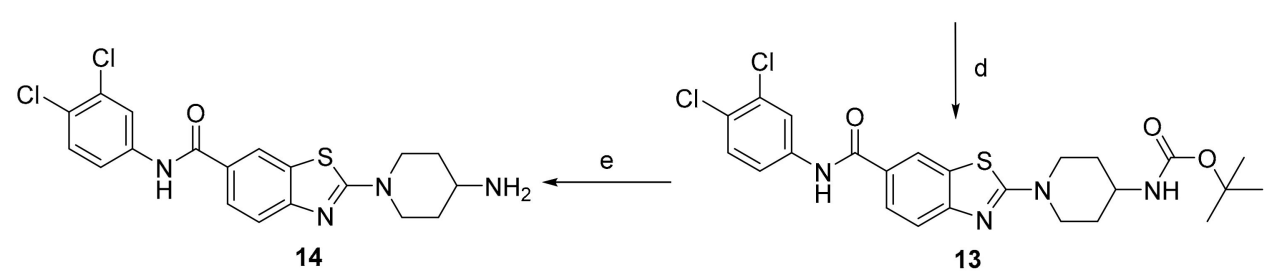

Scheme 3. Reagents and conditions: (a) (i) formaldehyde, DCM:MeOH = 1:1, r.t., 15 min; (ii) $\mathrm{NaCNBH}_{3}$, r.t., overnight; (b) 4-(N-Boc-amino)piperidine, THF, from r.t. to $70{ }^{\circ} \mathrm{C}$, overnight; (c) $1 \mathrm{M} \mathrm{NaOH}, 96 \% \mathrm{EtOH}, 100{ }^{\circ} \mathrm{C}, 2 \mathrm{~h}$; (d) (i) EDC, $\mathrm{HOBt}$, DIPEA, DMF, r.t., 20 min; (ii) respective amine, 1-3 days; (e) $\mathrm{CF}_{3} \mathrm{COOH}$, DCM, r.t., 1-3 days.

\subsection{Biological Evaluation}

All of the final compounds were tested for antiproliferative activities against the MCF-7 breast cancer cell line, using the MTS assay. The results obtained from the introduction of the changes in the substituents at position 6 are shown in Table 1. The unsubstituted benzene ring at this position provided the moderately active compound $\mathbf{5 a}$ $\left(\mathrm{IC}_{50}, 18.9 \pm 0.4 \mu \mathrm{M}\right)$, even though it lacked an additional hydrophobic substituent that is relevant for binding according to the pharmacophore model shown in Figure 3. Therefore, the introduction of a chlorine atom at the meta and/or para positions of the phenyl ring was designed to form additional hydrophobic interactions with the hydrophobic pocket of the proposed CTD binding site. Both substitution positions resulted in compounds $\mathbf{5 b} \mathbf{b} \mathbf{d}$ with similar potencies. The possibility of compounds to form a halogen bond was investigated by introducing fluorine (5e), bromine (5f), and iodine (5g) at the para position of the phenyl ring. The gradual increase in activity from $5 \mathrm{c}$ to the most potent compound $5 \mathrm{~g}$ ( $\mathrm{IC}_{50}$, $2.8 \pm 0.1 \mu \mathrm{M}$ ) correlated with the formation of halogen bonds by the individual atoms; however, the increase in activity might also be attributed to improved steric fit with the larger iodine substituent in $\mathbf{5 g}$. This last is also in agreement with compound $\mathbf{5 h}$, which suggests that there might be additional unused space in this part of the binding pocket. The introduction of the polar 4-methoxy group (5i) or increasing the distance between the basic center and aromatic moiety by introducing additional methylene groups $(\mathbf{5 j}-\mathbf{m})$, did not further improve the activity with respect to $\mathbf{5 a}$.

As chlorine is a more drug-like element than iodine and bromine [49], and as compound $\mathbf{5 c}$ showed promising activity in the cell-based assay, para-chlorophenyl was chosen as a suitable substituent on position 6 for further SAR exploration of position 2 on the benzothiazole ring. The antiproliferative activities against the MCF-7 cell line of these compounds are shown in Table 2.

First, the importance of the cationic center in the compounds was evaluated. This was because the previously developed benzothiazole-based Hsp90 CTD inhibitors did not contain a cationic center in their structure [34,35]. For this purpose, variously substituted piperidines were introduced at position 2 of the benzothiazole ring. The antiproliferative $\mathrm{IC}_{50}$ values for 4-methyl- (8n), 4-hydroxy- (8m), 4-carbamoyl- (8k) and 3-carbamoyl- (81) piperidines were all $>50 \mu \mathrm{M}$. Therefore, these compounds were considered inactive, and the importance of the cationic center for this inhibitor class was confirmed. 
Table 1. $\mathrm{IC}_{50}$ values for the antiproliferative activities of the synthesized benzothiazoles $5 \mathbf{a}-\mathbf{m}$ in the MCF-7 breast cancer cell line: exploration of the structure-activity relationships at position 6 of the benzothiazole moiety.

\begin{tabular}{|c|c|}
\hline Compound & $\mathrm{IC}_{50}(\mu \mathrm{M})$ \\
\hline 17-DMAG * & $0.9 \pm 0.1$ \\
\hline $5 a$ & $18.9 \pm 0.4$ \\
\hline $5 b$ & $6.5 \pm 0.1$ \\
\hline $5 c$ & $7.2 \pm 0.0$ \\
\hline $5 d$ & $6.3 \pm 0.5$ \\
\hline $5 e$ & $17.7 \pm 3.7$ \\
\hline $5 f$ & $4.3 \pm 0.0$ \\
\hline $5 g$ & $2.8 \pm 0.1$ \\
\hline $5 \mathrm{~h}$ & $6.6 \pm 0.4$ \\
\hline $5 i$ & $22.3 \pm 5.1$ \\
\hline $5 \mathbf{j}$ & $35.4 \pm 8.6$ \\
\hline $5 k$ & $13.3 \pm 1.5$ \\
\hline 51 & $15.0 \pm 0.1$ \\
\hline $5 \mathrm{~m}$ & $20.1 \pm 0.2$ \\
\hline
\end{tabular}

*17-DMAG, 17-dimethylaminoethylamino-17-demethoxygeldanamycin (Hsp90 N-terminal-domain inhibitor used as a positive control in all experiments). 
Table 2. $\mathrm{IC}_{50}$ values for the antiproliferative activities of the synthesized benzothiazoles $\mathbf{8 k}-\mathbf{n}$ and 9a-i in the MCF-7 breast cancer cell line: exploration of the structure-activity relationships at position 2 of the benzothiazole moiety.

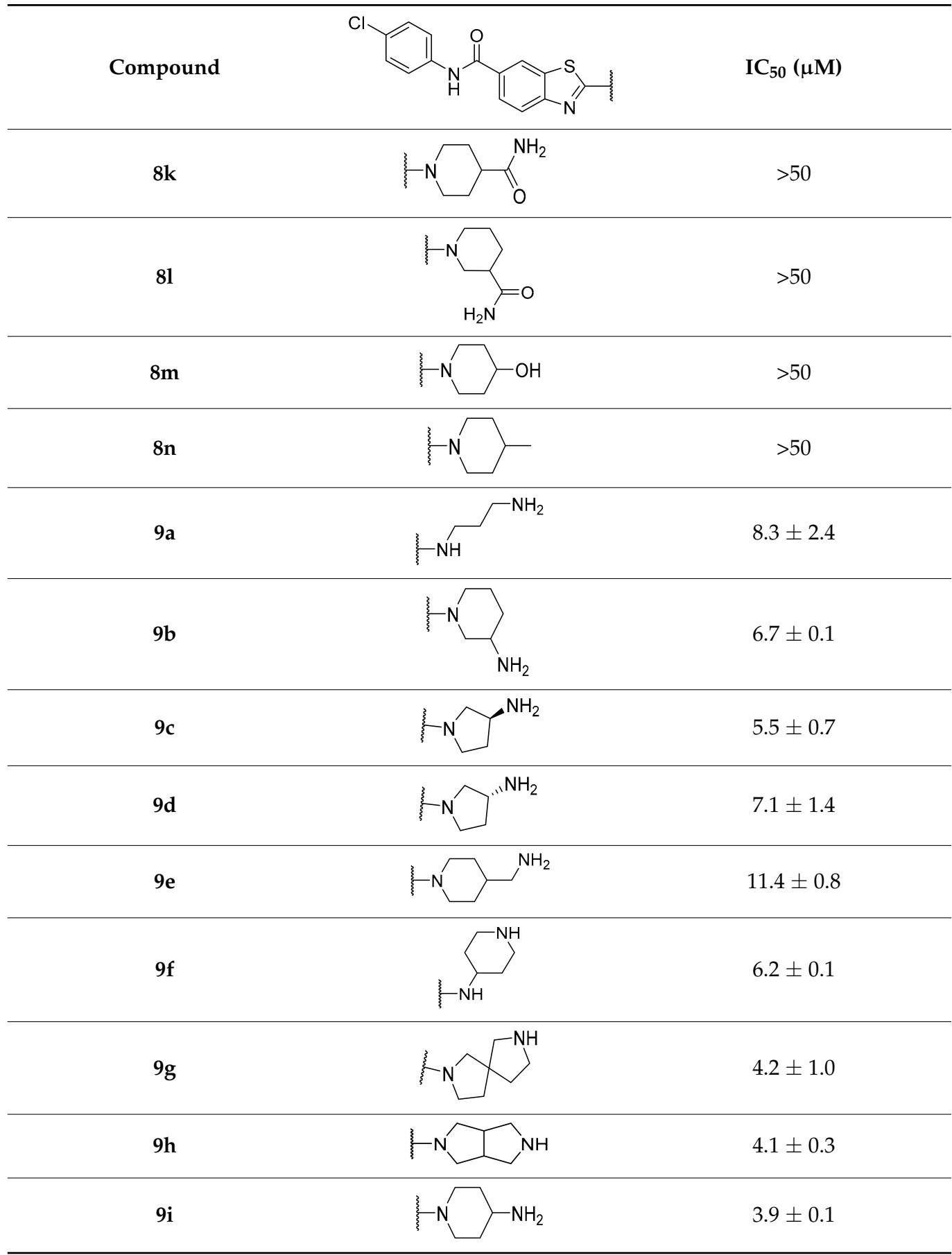

Next, the piperazine ring at position 2 of compound $5 \mathrm{c}$ was replaced by 1,3 diaminopropane (9a). This change resulted in an expected decrease in activity ( $\mathrm{IC}_{50}$, $8.3 \pm 2.4 \mu \mathrm{M})$, as the propyl chain is more flexible than piperazine. In compounds $\mathbf{9 b} \mathbf{- 9} \mathbf{d}$, the substituents in position 2 maintained approximately the same spacing of two carbon atoms between the two nitrogen atoms as in piperazine, which had a very limited effect on the activity $\left(\mathrm{IC}_{50}\right.$, from $5.5 \pm 0.7$ to $\left.7.1 \pm 1.4 \mu \mathrm{M}\right)$. The reduced potency of compound $9 \mathrm{e}$ $\left(\mathrm{IC}_{50}, 11.4 \pm 0.8 \mu \mathrm{M}\right)$ with a longer 4-aminomethyl-piperidine substituent highlights the importance of an appropriate distance between the basic center and the aromatic ring, as shown in the pharmacophore model in Figure 3. The optimal distance between the 
aromatic ring at position 6 of the benzothiazole and the cationic center appears to have been achieved with compounds 9 g-9i. Although the substituents of these inhibitors differed, the distances to the cationic center were similar. As compound $9 \mathbf{i}$ was the most potent $\left(\mathrm{IC}_{50}, 3.9 \pm 0.1 \mu \mathrm{M}\right)$, it was selected for further SAR investigations.

First, $N$-methyl (9j) and $N$-dimethyl (10) analogs of the primary amine of $9 \mathbf{i}$ were prepared and tested. The results, presented in Table 3 show that neither modification resulted in improved activity. The monomethylated analog $9 \mathbf{j}$ showed an almost unchanged potency $\left(\mathrm{IC}_{50}, 4.2 \pm 0.9 \mu \mathrm{M}\right.$ ) with respect to $9 \mathbf{i}$, with a slight decrease in activity for the tertiary amine $10\left(\mathrm{IC}_{50}, 5.3 \pm 1.1 \mu \mathrm{M}\right)$. This was not in agreement with our expectations, as many previously developed potent Hsp90 CTD inhibitors have contained a tertiary amine moiety in their structure $[28,29,31]$. In addition, compound $\mathbf{1 4}$ (Table 3) was synthesized as an analog of compound $\mathbf{5 d}$. Interestingly, with compound $\mathbf{1 4}$, the antiproliferative activity was half that of $9 \mathbf{i}\left(\mathrm{IC}_{50}, 7.4 \pm 0.5\right.$ vs. $3.9 \pm 0.1 \mu \mathrm{M}$, respectively).

Table 3. $\mathrm{IC}_{50}$ values for the antiproliferative activities of the $9 \mathbf{i}$ analogs evaluated in the MCF-7 breast cancer cell line.

Compound

Overall, the results of the biological evaluation of the antiproliferative activities against the MCF-7 cell line established the general SARs for this set of compounds. As shown in Figure 4, the cationic center at position 2 is obligatory, and its correct distance from the aromatic ring at position 6 is also very important.

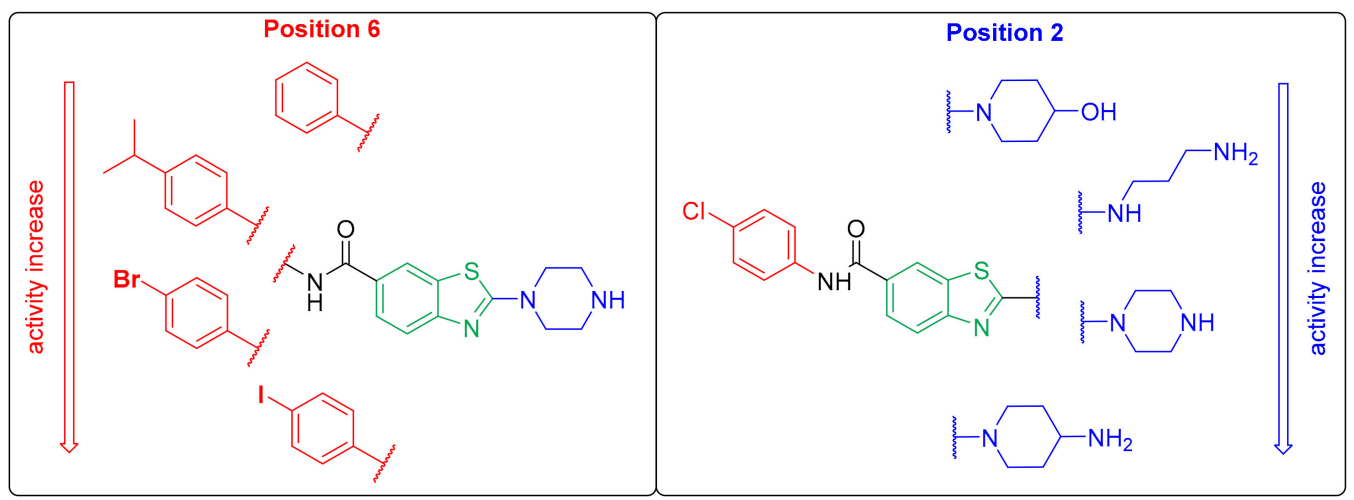

Figure 4. Structure-activity relationships of the benzothiazole based Hsp90 C-terminal-domain inhibitors.

To confirm that these inhibitors alter the biological activity of Hsp90, the expression levels of some of its client proteins that are relevant to cancer pathogenesis were examined using Western blotting: Akt, c-Raf, and estrogen receptor alpha (ER $\alpha)$. In addition, the 
expression levels of Hsp90 and Hsp70 in the treated cells were monitored to confirm that no HSR induction occurs, as non-induction of HSR is one of the main advantages of Hsp90 CTD inhibitors compared to ATP-competitive isoform non-selective inhibitors. As shown in Figure 5, Western blotting of lysates from the MCF-7 cells after treatment with compound 9i confirmed that the oncogenic proteins Akt, c-Raf, and ER $\alpha$ were downregulated. At the same time, compound 9i did not induce the HSR, as Hsp90 and Hsp70 were not upregulated. On the contrary, a known Hsp90 NTD inhibitor 17-DMAG that was used as a positive control resulted in significant upregulation of these heat shock proteins. These data confirmed that this new class of inhibitor modulates the activity of Hsp90 in a CTD allosteric manner, similar to the previously reported benzothiazole-based CTD inhibitors [35].

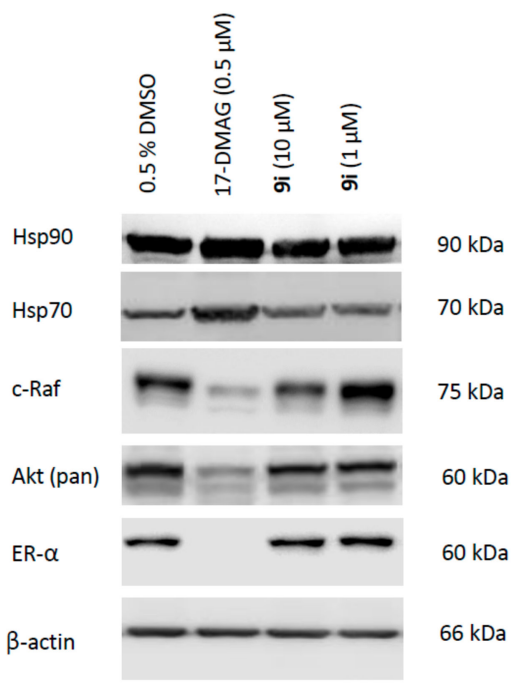

Figure 5. Representative Western blotting for the MCF-7 breast cancer cell line for Hsp90, Hsp70, Akt, c-Raf, and estrogen receptor alpha (ER- $\alpha$ ) after $24 \mathrm{~h}$ incubation with compound 9i, 17-DMAG (positive control) and $0.5 \%$ DMSO (vehicle).

\subsection{Molecular Modeling}

To study the possible binding mode of these benzothiazole-based Hsp90 CTD inhibitors, as $9 \mathbf{i}$ was one of the most potent compounds, it was docked in the Hsp90 $\beta$ CTD binding site in the conformation from the MD simulation trajectory from which the SBPM used for alignment in Figure 3 was derived [32]. From the analysis of the binding mode (Figure 6), it is apparent that the cationic center at position 2 of the benzothiazole forms an ionic interaction with the Glu489A side chain, while the benzothiazole scaffold forms hydrophobic interactions with the Leu664B and Leu670A side chains. The amide NH group forms a hydrogen bond with the Leu664B backbone carbonyl group, and the 4chlorophenyl ring interacts with the Ile486B side chain. Eight out of ten highest ranked docking poses of $9 \mathbf{i}$ were predicted to adopt similar orientation in the binding site and form similar interactions.

In the absence of any co-crystal structure of the Hsp90-CTD inhibitor complex, we further validated the proposed binding mode of $9 \mathrm{i}$ using $500 \mathrm{~ns}$ MD simulations. The interaction features between $9 i$ and the allosteric Hsp90 CTD binding site during the MD simulation were analyzed using the MD analysis tool in LigandScout 4.4 Expert. The MD interaction map in Figure 7 shows the percentage appearance of each pharmacophore feature during the MD trajectory and the amino acid residues associated with these features. The most conserved interactions during the $\mathrm{MD}$ simulation are ionic interactions with the Glu489A side chain (71\%), hydrophobic interactions with Leu664B (81\%), Leu670B (53\%) and hydrogen bonds with Leu664B (58\%), Leu670A (42\%) and Leu670B (49\%). Figure 8 shows the plot of the most frequently appearing unique SBPMs, in terms of the total number 
of interaction features for each SBPM versus the frequency (\#Appearances). The most frequent model (seen 141 times) showed 7 interaction features, including a positive ionizable feature associated with the primary amine and Glu489A, hydrophobic interactions with Leu664A, Leu670A, Leu664B, and Leu670B, and hydrogen bonds with Leu664B, Leu670A, and Leu670B (Figure 9). This pharmacophore model frequently appeared between $280 \mathrm{~ns}$ and $500 \mathrm{~ns}$ of the MD simulation. The second most frequent model (seen 123 times) was the same as the docking model shown in Figure 6 and is represented in the first part of the MD simulation (until $140 \mathrm{~ns}$ ). However, the binding pose of $9 \mathrm{i}$ does not significantly change between the docking pose and poses derived from the MD simulation trajectory (Figure 9).

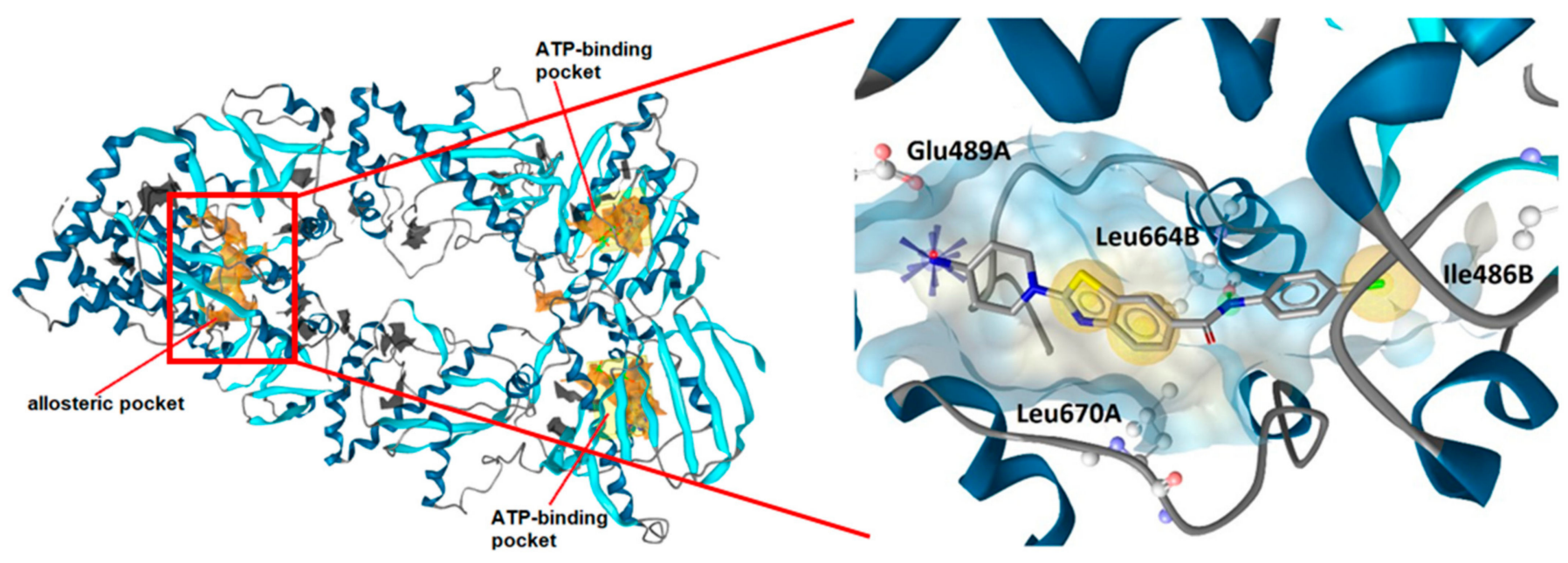

Figure 6. Interactions of compound $9 \mathbf{i}$ with the Hsp90 C-terminal-domain binding site. The pharmacophore features are hydrophobics (yellow spheres), hydrogen bond donor (green arrow), and positive ionizable (blue star). For clarity, only the amino acids that interact with $9 \mathbf{i}$ are shown.

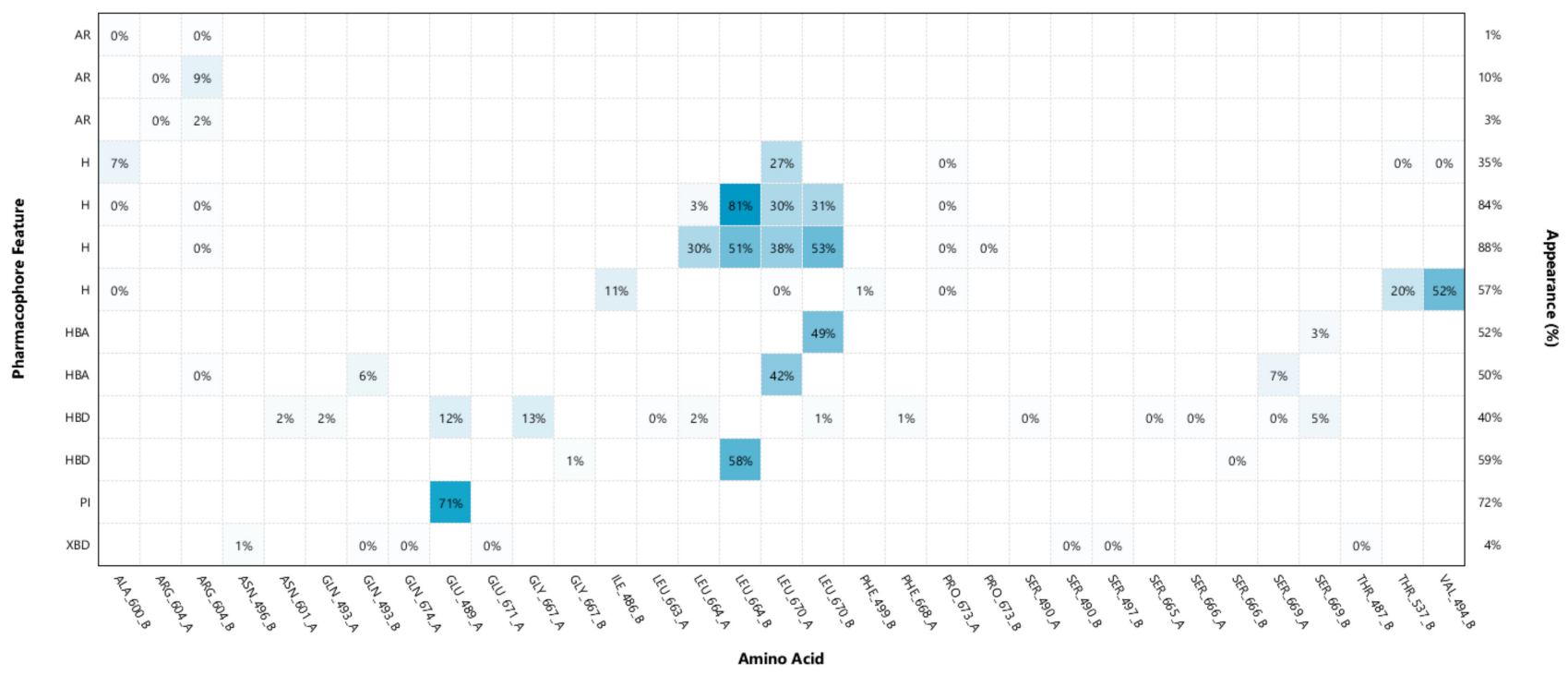

Figure 7. MD Interaction map obtained by analyzing interactions of compound 9i with Hsp90 CTD binding site residues in the $500 \mathrm{~ns}$ MD simulation trajectory. Amino acid name and numbering is shown on $\mathrm{x}$-axis, pharmacophore feature type on the left y-axis (H-hydrophobic, HBA—hydrogen bond acceptor, HBD—hydrogen bond donor, PI—positive ionizable, $\mathrm{XBD}$ - halogen bond), \% appearance on the right $\mathrm{y}$-axis. 


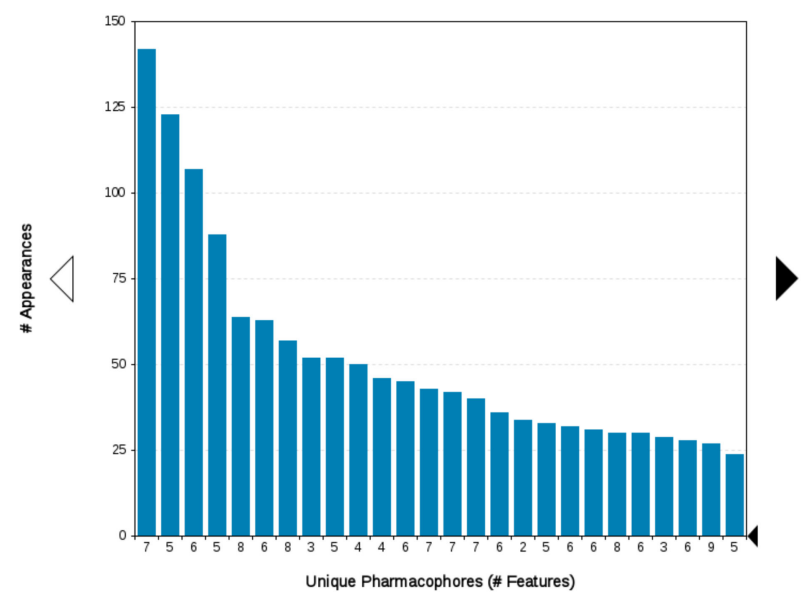

Figure 8. Plot of the most frequent unique structure-based pharmacophore models derived from the molecular dynamics simulations of the Hsp90 C-terminal domain in complex with 9 i. The numbers below the bars indicate the numbers of interaction features observed during molecular dynamics simulation for the pharmacophore models.

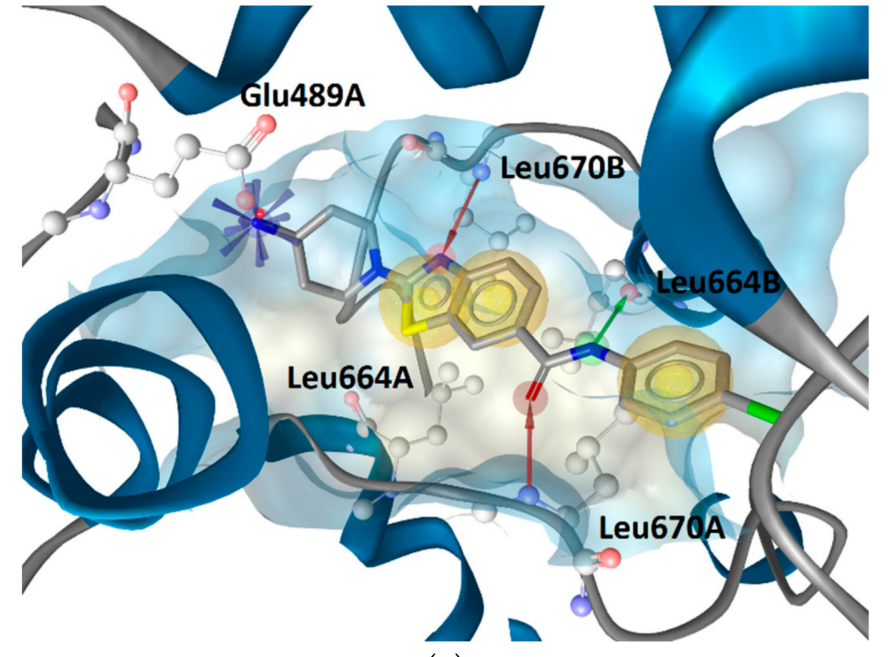

(a)

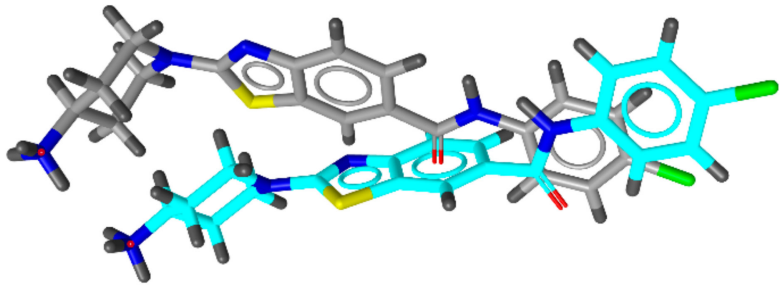

(b)

Figure 9. (a) The most frequently occurring interactions and binding modes of compound 9i in the Hsp90 C-terminal-domain binding site during the $500 \mathrm{~ns}$ molecular dynamics simulation. The pharmacophore features are as follows: hydrophobics (yellow spheres), hydrogen bond donor (green arrow), hydrogen bond acceptor (red arrow), and positive ionizable (blue star). For clarity, only the amino acids that interact with $\mathbf{9 i}$ are shown. (b) Superposition of the docking pose (in cyan) and the MD conformation (in grey) of $\mathbf{9 i}$ representing the most frequently appearing pharmacophore model.

The Hsp90 CTD binding site of 9 i partially overlaps with the previously studied binding sites [30,50]. The amino acid residues Glu489 (Glu497 in Hsp90 $\alpha$ ), Ser669 (Ser677 in Hsp90 $\alpha$ ), and Leu664 (Leu672 in Hsp90 $\alpha$ ) that interact with 9i (Figure 7) also form ionic interactions and hydrogen bonds with bisphenol derivative [50] and novobiocin analogues [30]. In addition, 9i forms hydrophobic contacts with Ile486 (Ile494 in Hsp90 $\alpha$ ) (Figure 7), which was identified by protein NMR spectroscopy studies as important for the binding of novobiocin analogues KU-32 and KU-596 to Hsp90 CTD [51]. However, this binding site does not overlap with that of the peptide-based inhibitor AX [52].

\section{Conclusions}

A focused library of novel benzothiazole-based Hsp90 CTD inhibitors was designed by combining ligand-based and structure-based pharmacophore modeling. To develop the SARs of this new Hsp90 CTD inhibitor class, a series of 2,6-disubstituted benzothiazoles 
was synthesized and biologically evaluated. The most potent compounds showed low micromolar antiproliferative activities against the MCF-7 breast cancer cell line. Compound 9i showed dose-dependent degradation of Hsp90 client proteins and did not induce the HSR, which is a characteristic feature of Hsp90 CTD inhibitors. In the absence of a crystal structure of a Hsp90-CTD inhibitor complex, the binding mode of $9 \mathbf{i}$ was investigated through a combination of docking and MD simulations in conjunction with structure-based pharmacophore modeling, which were consistent with the observed SARs. Analysis of the binding interactions of $9 \mathbf{i}$ in the Hsp90 CTD binding site during MD simulation revealed conserved interactions with several amino acid residues that can be used for the design of novel Hsp90 CTD inhibitors. The results of this study highlight the benzothiazole moiety as a suitable scaffold for the design of Hsp90 CTD inhibitors with antiproliferative activities and provide the basis for structure-based optimization toward more potent compounds.

Supplementary Materials: The following are available online at https:/ / www.mdpi.com/article/ 10.3390 / pharmaceutics13081283/s1, Figure S1. 1H NMR spectrum of compound 1, Figure S2. 13C NMR spectrum of compound 1, Figure S3. 1H NMR spectrum of compound 2, Figure S4. 13C NMR spectrum of compound 2, Figure S5. 1H NMR spectrum of compound 3, Figure S6. 13C NMR spectrum of compound 3, Figure S7. 1H NMR spectrum of compound 4c, Figure S8. 1H NMR spectrum of compound 5a, Figure S9. 13C NMR spectrum of compound 5a, Figure S10. HPLC chromatogram for compound 5a, Figure S11. 1H NMR spectrum of compound 5b, Figure S12. 13C NMR spectrum of compound $\mathbf{5 b}$, Figure S13. HPLC chromatogram for compound $\mathbf{5 b}$, Figure S14. $1 \mathrm{H}$ NMR spectrum of compound 5c, Figure S15. 13C NMR spectrum of compound 5c, Figure S16. HPLC chromatogram for compound 5c, Figure S17. 1H NMR spectrum of compound 5d, Figure S18. 13C NMR spectrum of compound 5d, Figure S19. HPLC chromatogram for compound 5d, Figure S20. 1H NMR spectrum of compound 5e, Figure S21. 19F NMR spectrum of compound 5e, Figure S22. 13C NMR spectrum of compound 5e, Figure S23. HPLC chromatogram for compound 5e, Figure S24. 1H NMR spectrum of compound 5f, Figure S25. 13C NMR spectrum of compound 5f, Figure S26. HPLC chromatogram for compound 5f, Figure S27. 1H NMR spectrum of compound 5g, Figure S28. 13C NMR spectrum of compound 5g, Figure S29. HPLC chromatogram for compound 5g, Figure S30. 1H NMR spectrum of compound 5h, Figure S31. 13C NMR spectrum of compound 5 h, Figure S32. HPLC chromatogram for compound $5 \mathbf{h}$, Figure S33. 1H NMR spectrum of compound 5i, Figure S34. 13C NMR spectrum of compound 5i, Figure S35. HPLC chromatogram for compound 5i, Figure S36. 1H NMR spectrum of compound 5j, Figure S37. 13C NMR spectrum of compound 5j, Figure S38. HPLC chromatogram for compound 5j, Figure S39. 1H NMR spectrum of compound 5k, Figure S40. 13C NMR spectrum of compound 5k, Figure S41. HPLC chromatogram for compound 5k, Figure S42. 1H NMR spectrum of compound 51, Figure S43. 13C NMR spectrum of compound 51, Figure S44. HPLC chromatogram for compound 5l, Figure S45. 1H NMR spectrum of compound 5m, Figure S46. 13C NMR spectrum of compound $5 \mathrm{~m}$, Figure S47. HPLC chromatogram for compound $5 \mathrm{~m}$, Figure $\mathrm{S} 48.1 \mathrm{H}$ NMR spectrum of compound 6, Figure S49. 13C NMR spectrum of compound 6, Figure S50. 1H NMR spectrum of compound 7, Figure S51. 13C NMR spectrum of compound 7, Figure S52. 1H NMR spectrum of compound 8i, Figure S53. 13C NMR spectrum of compound 8i, Figure S54 1H NMR spectrum of compound 8k, Figure S55. 13C NMR spectrum of compound 8k, Figure S56. HPLC chromatogram for compound 8k, Figure S57 1H NMR spectrum of compound 81, Figure S58. 13C NMR spectrum of compound 81, Figure S59. HPLC chromatogram for compound 81, Figure S60 1H NMR spectrum of compound 8m, Figure S61. 13C NMR spectrum of compound 8m, Figure S62. HPLC chromatogram for compound 8m, Figure S63 1H NMR spectrum of compound 8n, Figure S64. 13C NMR spectrum of compound 8n, Figure S65. HPLC chromatogram for compound 8n, Figure S66 1H NMR spectrum of compound 9a, Figure S67. 13C NMR spectrum of compound 9a, Figure S68. HPLC chromatogram for compound 9a, Figure S69 1H NMR spectrum of compound 9b, Figure S70. 13C NMR spectrum of compound $\mathbf{9 b}$, Figure S71. HPLC chromatogram for compound $\mathbf{9 b}$, Figure S72 1H NMR spectrum of compound 9c, Figure S73. 13C NMR spectrum of compound 9c, Figure S74. HPLC chromatogram for compound 9c, Figure S75 1H NMR spectrum of compound 9d, Figure S76. 13C NMR spectrum of compound 9d, Figure S77. HPLC chromatogram for compound 9d, Figure S78 1H NMR spectrum of compound 9e, Figure S79. 13C NMR spectrum of compound 9e, Figure S80. HPLC chromatogram for compound 9e, Figure S81 1H NMR spectrum of compound 9f, Figure S82. 13C NMR spectrum of compound 9f, Figure S83. HPLC chromatogram for compound 9f, Figure S84 
1H NMR spectrum of compound 9g, Figure S85. 13C NMR spectrum of compound $\mathbf{9 g}$, Figure S86. HPLC chromatogram for compound $\mathbf{9 g}$, Figure S87 1H NMR spectrum of compound 9 h, Figure S88. 13C NMR spectrum of compound $\mathbf{9 h}$, Figure S89. HPLC chromatogram for compound $\mathbf{9 h}$, Figure S90 1H NMR spectrum of compound 9i, Figure S91. 13C NMR spectrum of compound 9i, Figure S92. HPLC chromatogram for compound $\mathbf{9 i}$, Figure S93 1H NMR spectrum of compound $\mathbf{9 j}$, Figure S94. 13C NMR spectrum of compound 9j, Figure S95. HPLC chromatogram for compound 9j, Figure S96 1H NMR spectrum of compound 10, Figure S97. 13C NMR spectrum of compound 10, Figure S98. HPLC chromatogram for compound 10, Figure S99 1H NMR spectrum of compound 14, Figure S100. 13C NMR spectrum of compound 14, Figure S101. HPLC chromatogram for compound 14.

Author Contributions: Conceptualization, T.T.; formal analysis, T.T.; funding acquisition, T.T.; investigation, J.D., Ž.Z., M.D. and T.T.; methodology, J.D., Ž.Z., M.D., M.G. and T.T.; resources, T.T.; supervision, L.P.M., M.G., N.Z. and T.T.; visualization, J.D. and T.T.; writing-original draft, J.D.; writing-review and editing, Ž.Z., M.D., L.P.M., M.G., N.Z. and T.T. All authors have read and agreed to the published version of the manuscript.

Funding: This research was funded by the Slovenian Research Agency (Grant No. P1-0208, J1-1717). The APC was funded by the Slovenian Research Agency (Grant No. J1-1717).

Institutional Review Board Statement: Not applicable.

Informed Consent Statement: Not applicable.

Data Availability Statement: The data presented in this study are available on request from the corresponding author.

Acknowledgments: The authors thank Chris Berrie for editing the manuscript. We thank OpenEye Scientific Software, Santa Fe, N.M., for free academic licenses for the use of their software.

Conflicts of Interest: The authors declare no conflict of interest. The funders had no role in the design of the study; in the collection, analyses, or interpretation of data; in the writing of the manuscript, or in the decision to publish the results.

\section{Appendix A}

Ethyl 2-bromobenzo[d]thiazole-6-carboxylate (1): Ethyl 2-aminobenzo[d]thiazole-6carboxylate $(4.00 \mathrm{~g}, 18.00 \mathrm{mmol})$ and $\mathrm{CuBr}_{2}(8.04 \mathrm{~g}, 35.99 \mathrm{mmol})$ were dissolved in acetonitrile $(90 \mathrm{~mL})$. tert-Butyl nitrite $\left(4.28 \mathrm{~mL}, 35.99 \mathrm{mmol}, 867 \mathrm{mg} \mathrm{mL}^{-1}\right)$ was added in an ice bath, and the reaction mixture was stirred for $1 \mathrm{~h}$ at room temperature. The solvent was then removed under reduced pressure, and the residue was taken up in ethyl acetate $(150 \mathrm{~mL})$ and saturated $\mathrm{NH}_{4} \mathrm{Cl}(50 \mathrm{~mL})$. The organic phase was additionally washed with saturated $\mathrm{NH}_{4} \mathrm{Cl}(2 \times 50 \mathrm{~mL})$ and brine $(50 \mathrm{~mL})$. The organic phase was dried over $\mathrm{Na}_{2} \mathrm{SO}_{4}$, filtered, and the solvent was evaporated under reduced pressure. Yield: $3.95 \mathrm{~g}(77 \%)$; brown amorphous powder; $\mathrm{R}_{\mathrm{f}}(\mathrm{DCM}: \mathrm{MeOH}=30: 1)=0.74 ;{ }^{1} \mathrm{H} \mathrm{NMR}\left(400 \mathrm{MHz}, \mathrm{CDCl}_{3}\right.$, $\left.25^{\circ} \mathrm{C}, \mathrm{TMS}\right): \delta=8.55\left(\mathrm{~d}, J=1.5 \mathrm{~Hz}, 1 \mathrm{H}, \mathrm{Ar}-H_{7}\right), 8.16\left(\mathrm{dd}, J_{1}=8.5 \mathrm{~Hz}, J_{2}=1.5 \mathrm{~Hz}, 1 \mathrm{H}\right.$, Ar- $\left.H_{5}\right), 8.02\left(\mathrm{~d}, J=8.5 \mathrm{~Hz}, 1 \mathrm{H}, \mathrm{Ar}-\mathrm{H}_{4}\right), 4.43\left(\mathrm{q}, J=7.1 \mathrm{~Hz}, 2 \mathrm{H}, \mathrm{COO}-\mathrm{CH}_{2}-\mathrm{CH}_{3}\right), 1.43 \mathrm{ppm}(\mathrm{t}$, $\left.J=7.1 \mathrm{~Hz}, 3 \mathrm{H}, \mathrm{COO}-\mathrm{CH}_{2}-\mathrm{CH}_{3}\right) ;{ }^{13} \mathrm{C}$ NMR $\left(101 \mathrm{MHz}, \mathrm{CDCl}_{3}, 25^{\circ} \mathrm{C}, \mathrm{TMS}\right): \delta=165.8,155.1$, $142.4,137.3,127.9,127.8,122.9,122.5,61.5,14.4$ ppm; LC-MS (ESI+): $m / z 285.9[\mathrm{M}+\mathrm{H}]^{+}$ (calcd. $m / z=284.9$ for $\mathrm{C}_{10} \mathrm{H}_{8} \mathrm{BrNO}_{2} \mathrm{~S}$ ).

Ethyl 2-(4-Boc-piperazin-1-yl)benzo[d]thiazole-6-carboxylate (2): Ethyl 2-bromobenzo[d] thiazole-6-carboxylate $(1.98 \mathrm{~g}, 6.91 \mathrm{mmol})$ and 1-Boc-piperazine $(3.22 \mathrm{~g}, 17.3 \mathrm{mmol})$ were dissolved in THF $(100 \mathrm{~mL})$. The reaction mixture was then stirred overnight at room temperature. The precipitate formed was pressure filtered off, and the solvent was evaporated under reduced pressure. The residue was taken up in ethyl acetate $(100 \mathrm{~mL})$ and washed with $1 \%(w / v)$ citric acid $(3 \times 50 \mathrm{~mL})$ and saturated $\mathrm{NaCl}(50 \mathrm{~mL})$. The organic phase was dried over $\mathrm{Na}_{2} \mathrm{SO}_{4}$, filtered, and the solvent was evaporated under reduced pressure. Yield: $2.63 \mathrm{~g}(97 \%)$; yellow amorphous powder; $\mathrm{R}_{\mathrm{f}}$ (EtOAc:Hex $\left.=1: 3\right)=0.29 ;{ }^{1} \mathrm{H}$ NMR $(400 \mathrm{MHz}$, $\mathrm{CDCl}_{3}, 25^{\circ} \mathrm{C}$, TMS): $\delta=8.32\left(\mathrm{~d}, J=1.5 \mathrm{~Hz}, 1 \mathrm{H}, \mathrm{Ar}-\mathrm{H}_{7}\right), 8.01\left(\mathrm{dd}, J_{1}=8.5 \mathrm{~Hz}, J_{2}=1.8 \mathrm{~Hz}, 1 \mathrm{H}\right.$, Ar- $\left.H_{5}\right), 7.53\left(\mathrm{~d}, J=8.5 \mathrm{~Hz}, 1 \mathrm{H}, \mathrm{Ar}-\mathrm{H}_{4}\right), 4.38\left(\mathrm{q}, J=7.1 \mathrm{~Hz}, 2 \mathrm{H}, \mathrm{COO}-\mathrm{CH}_{2}-\mathrm{CH}_{3}\right), 3.69-3.63(\mathrm{~m}$, $4 \mathrm{H}, 2 \times$ piperazine- $\left.\mathrm{CH}_{2}\right), 3.63-3.56\left(\mathrm{~m}, 4 \mathrm{H}, 2 \times\right.$ piperazine- $\left.\mathrm{CH}_{2}\right), 1.49\left(\mathrm{~s}, 9 \mathrm{H}, \mathrm{COC}\left(\mathrm{CH}_{3}\right)_{3}\right)$, 
$1.40 \mathrm{ppm}\left(\mathrm{t}, \mathrm{J}=7.1 \mathrm{~Hz}, 3 \mathrm{H}, \mathrm{COO}-\mathrm{CH}_{2}-\mathrm{CH}_{3}\right) ;{ }^{13} \mathrm{C} \mathrm{NMR}\left(101 \mathrm{MHz}, \mathrm{CDCl}_{3}, 25{ }^{\circ} \mathrm{C}, \mathrm{TMS}\right)$ : $\delta=170.7,166.4,156.3,154.5,130.6,128.0,123.7,122.8,118.5,80.6$ (2C), 60.9, 48.2 (2C), 28.4 (3C), 14.4 ppm; LC-MS (ESI+): $m / z 392.1[\mathrm{M}+\mathrm{H}]^{+}$(calcd. $m / z=391.2$ for $\mathrm{C}_{19} \mathrm{H}_{25} \mathrm{~N}_{3} \mathrm{O}_{4} \mathrm{~S}$ ).

2-(4-Boc-piperazin-1-yl)benzo[d]thiazole-6-carboxylic acid (3): Compound 2 (2.60 g, $6.64 \mathrm{mmol})$ was suspended in $\mathrm{EtOH}(96 \%, 50 \mathrm{~mL})$ and $\mathrm{NaOH}_{(\mathrm{aq})}(33.2 \mathrm{~mL}, 2 \mathrm{M}, 66.4 \mathrm{mmol})$ was added. The mixture was heated to $100{ }^{\circ} \mathrm{C}$ and left to stir for $1 \mathrm{~h}$. Afterwards, the reaction mixture was cooled and acidified to $\mathrm{pH} 3$, using $2 \mathrm{M} \mathrm{HCl}_{(\mathrm{aq})}$. The precipitate that formed was then filtered off under pressure and left to dry. Yield: $2.25 \mathrm{~g} \mathrm{(93 \% );}$ yellow amorphous powder; $\mathrm{R}_{\mathrm{f}}($ EtOAc: $\mathrm{Hex}=1: 1)=0,16 ;{ }^{1} \mathrm{H} \mathrm{NMR}\left(400 \mathrm{MHz}, \mathrm{CDCl}_{3}, 25{ }^{\circ} \mathrm{C}\right.$, TMS): $\delta=8.39\left(\mathrm{~d}, J=1.6 \mathrm{~Hz}, 1 \mathrm{H}, \mathrm{Ar}-H_{7}\right), 8.08\left(\mathrm{dd}, J_{1}=8.5 \mathrm{~Hz}, J_{2}=1.6 \mathrm{~Hz}, 1 \mathrm{H}, \mathrm{Ar}-H_{5}\right)$, $7.58\left(\mathrm{~d}, J=8.5 \mathrm{~Hz}, 1 \mathrm{H}, \mathrm{Ar}-\mathrm{H}_{4}\right), 3.73-3.66\left(\mathrm{~m}, 4 \mathrm{H}, 2 \times\right.$ piperazine- $\left.\mathrm{CH}_{2}\right), 3.65-3.58(\mathrm{~m}, 4 \mathrm{H}$, $2 \times$ piperazine- $\left.\mathrm{CH}_{2}\right), 1.50 \mathrm{ppm}\left(\mathrm{s}, 9 \mathrm{H}, \mathrm{COC}\left(\mathrm{CH}_{3}\right)_{3}\right) ;{ }^{13} \mathrm{C} \mathrm{NMR}\left(101 \mathrm{MHz},\left[\mathrm{D}_{6}\right] \mathrm{DMSO}, 25{ }^{\circ} \mathrm{C}\right.$, TMS): $\delta=170.9,167.6,156.5,154.2,130.9,128.1,123.8,123.6,118.4,79.8(2 \mathrm{C}), 48.2(2 \mathrm{C})$, 28.5 ppm (3C); LC-MS (ESI+): $m / z 364.1[\mathrm{M}+\mathrm{H}]^{+}$(calcd. $m / z=363.1$ for $\mathrm{C}_{17} \mathrm{H}_{21} \mathrm{~N}_{3} \mathrm{O}_{4} \mathrm{~S}$ ).

\section{General procedure for amide coupling (4a-m)}

The amide coupling reactions were performed under an argon atmosphere. 2-Substituted benzo[ $d]$ thiazole-6-carboxylic acid (1 equiv) was dissolved in DMF. EDC (1.2 equiv), HOBT (1.3 equiv) and DIPEA (2.5 equiv) were added in an ice bath. After $20 \mathrm{~min}$, the respective amine (1.2 equiv) was added, and the reaction mixture was stirred for 1-3 days at room temperature. When the activated ester that formed with HOBt was too stable to further react with the respective aniline at r.t. (according to liquid chromatography-mass spectrometry analysis), the temperature of the reaction mixture was increased to $70{ }^{\circ} \mathrm{C}$ (for $\mathbf{4 b}-\mathbf{d}, \mathbf{4 g}$ ) and stirred overnight. The solvent was then removed under reduced pressure, and the residue was taken up in ethyl acetate $(\sim 100 \mathrm{~mL})$ and washed with $1 \mathrm{M} \mathrm{NaOH}(3 \times 50 \mathrm{~mL})$, $1 \%(w / v)$ citric acid $(3 \times 50 \mathrm{~mL})$ and with saturated $\mathrm{NaCl}(50 \mathrm{~mL})$. The organic phase was dried over $\mathrm{Na}_{2} \mathrm{SO}_{4}$, filtered, and the solvent was evaporated under reduced pressure. The crude product was purified with precipitation from a mixture of ethyl acetate and hexane.

4-(6-(Phenylcarbamoyl)benzo[d]thiazol-2-yl)-1-Boc-piperazine (4a): Yield: $216 \mathrm{mg}$ (49\%); yellow amorphous powder; $\mathrm{R}_{\mathrm{f}}($ EtOAc:Hex $=2: 1)=0.54 ;{ }^{1} \mathrm{H}$ NMR $\left(400 \mathrm{MHz},\left[\mathrm{D}_{6}\right] \mathrm{DMSO}\right.$, $\left.25{ }^{\circ} \mathrm{C}, \mathrm{TMS}\right): \delta=10.18$ (s, 1H, Ar-NH-COR), 8.41 (d, $\left.J=1.8 \mathrm{~Hz}, 1 \mathrm{H}, \mathrm{Ar}-H_{7}\right), 7.91$ (dd, $\left.J_{1}=8.5 \mathrm{~Hz}, J_{2}=1.8 \mathrm{~Hz}, 1 \mathrm{H}, \mathrm{Ar}-H_{5}\right), 7.78(\mathrm{~d}, J=7.6 \mathrm{~Hz}, 2 \mathrm{H}, 2 \times \mathrm{Ar}-H), 7.55(\mathrm{~d}, J=8.5 \mathrm{~Hz}$, $\left.1 \mathrm{H}, \mathrm{Ar}-\mathrm{H}_{4}\right), 7.35(\mathrm{t}, J=7.9 \mathrm{~Hz}, 2 \mathrm{H}, 2 \times \mathrm{Ar}-\mathrm{H}), 7.09(\mathrm{t}, J=7.4 \mathrm{~Hz}, 1 \mathrm{H}, \mathrm{Ar}-\mathrm{H}), 3.69-3.58(\mathrm{~m}, 4 \mathrm{H}$, $2 \times$ piperazine- $\left.\mathrm{CH}_{2}\right), 3.55-3.45\left(\mathrm{~m}, 4 \mathrm{H}, 2 \times\right.$ piperazine- $\left.\mathrm{CH}_{2}\right), 1.44 \mathrm{ppm}\left(\mathrm{s}, 9 \mathrm{H}, \mathrm{COC}\left(\mathrm{CH}_{3}\right)_{3}\right)$; ${ }^{13} \mathrm{C}\left(101 \mathrm{MHz},\left[\mathrm{D}_{6}\right] \mathrm{DMSO}, 25{ }^{\circ} \mathrm{C}, \mathrm{TMS}\right): \delta=170.4,165.5,155.5,154.3,139.9,130.8,129.0$ (2C), 128.2, 126.6, 123.9, 121.7, 120.7 (2C), 118.3, 79.8 (2C), 48.2 (2C), 28.5 ppm (3C); LC-MS (ESI+): $m / z 439.1[\mathrm{M}+\mathrm{H}]^{+}$(calcd. $m / z=438.2$ for $\mathrm{C}_{23} \mathrm{H}_{26} \mathrm{~N}_{4} \mathrm{O}_{3} \mathrm{~S}$ ).

4-(6-((3-Chlorophenyl)carbamoyl)benzo[d]thiazol-2-yl)-1-Boc-piperazine (4b): Yield:

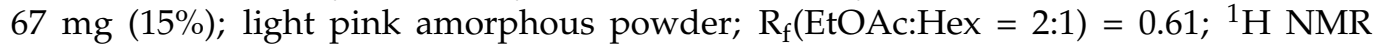
(400 MHz, [D $\left.]_{\text {DMSO }} 25^{\circ} \mathrm{C}, \mathrm{TMS}\right): \delta=10.34$ (s, 1H, Ar-NH-COR), $8.41(\mathrm{~d}, J=1.9 \mathrm{~Hz}, 1 \mathrm{H}$, $\left.\operatorname{Ar}-H_{7}\right), 7.98(\mathrm{t}, J=2.0 \mathrm{~Hz}, 1 \mathrm{H}, \mathrm{Ar}-H), 7.91\left(\mathrm{dd}, J_{1}=8.5 \mathrm{~Hz}, J_{2}=1.9 \mathrm{~Hz}, 1 \mathrm{H}, \mathrm{Btz}-H_{5}\right), 7.71$ $\left(\mathrm{ddd}, J_{1}=8.2 \mathrm{~Hz}, J_{2}=2.0 \mathrm{~Hz}, J_{3}=0.9 \mathrm{~Hz}, 1 \mathrm{H}, \mathrm{Ar}-H\right), 7.56\left(\mathrm{~d}, J=8.5 \mathrm{~Hz}, 1 \mathrm{H}, \mathrm{Ar}-H_{4}\right), 7.38(\mathrm{t}$, $J=8.2 \mathrm{~Hz}, 1 \mathrm{H}, \mathrm{Ar}-H), 7.15\left(\mathrm{ddd}, J_{1}=8.2 \mathrm{~Hz}, J_{2}=2.0 \mathrm{~Hz}, J_{3}=0.9 \mathrm{~Hz}, 1 \mathrm{H}, \mathrm{Ar}-H\right), 3.65-3.60$ $\left(\mathrm{m}, 4 \mathrm{H}, 2 \times\right.$ piperazine- $\left.\mathrm{CH}_{2}\right), 3.53-3.47\left(\mathrm{~m}, 4 \mathrm{H}, 2 \times\right.$ piperazine- $\left.\mathrm{CH}_{2}\right), 1.44 \mathrm{ppm}(\mathrm{s}, 9 \mathrm{H}$, $\left.\mathrm{COC}\left(\mathrm{CH}_{3}\right)_{3}\right)$; LC-MS (ESI+): $m / z 472.8[\mathrm{M}+\mathrm{H}]^{+}$(calcd. $m / z=471.1$ for $\mathrm{C}_{24} \mathrm{H}_{26} \mathrm{Cl}_{2} \mathrm{~N}_{4} \mathrm{O}_{3} \mathrm{~S}$ ).

4-(6-((4-Chlorophenyl)carbamoyl)benzo[d]thiazol-2-yl)-1-Boc-piperazine (4c): Yield: $258 \mathrm{mg}(48 \%)$; off-white amorphous powder; $\mathrm{R}_{\mathrm{f}}($ EtOAc:Hex $=1: 2)=0.39 ;{ }^{1} \mathrm{H} \mathrm{NMR}$ (400 MHz, [D $\left.]_{\text {DMSO }} 25^{\circ} \mathrm{C}, \mathrm{TMS}\right): \delta=10.31$ (s, $\left.1 \mathrm{H}, \mathrm{Ar}-\mathrm{NH}-\mathrm{COR}\right), 8.40(\mathrm{~d}, J=1.8 \mathrm{~Hz}, 1 \mathrm{H}$, $\left.\mathrm{Ar}-\mathrm{H}_{7}\right), 7.91\left(\mathrm{dd}, J_{1}=8.5, J_{2}=1.8 \mathrm{~Hz}, 1 \mathrm{H}, \mathrm{Ar}-H_{5}\right), 7.82(\mathrm{~d}, J=8.9 \mathrm{~Hz}, 2 \mathrm{H}, 2 \times \mathrm{Ar}-H), 7.55(\mathrm{~d}$, $\left.J=8.4 \mathrm{~Hz}, 1 \mathrm{H}, \mathrm{Ar}-\mathrm{H}_{4}\right), 7.41(\mathrm{~d}, J=8.9 \mathrm{~Hz}, 2 \mathrm{H}, 2 \times \mathrm{Ar}-\mathrm{H}), 3.69-3.58(\mathrm{~m}, 4 \mathrm{H}, 2 \times$ piperazine$\left.\mathrm{CH}_{2}\right), 3.54-3.46\left(\mathrm{~m}, 4 \mathrm{H}, 2 \times\right.$ piperazine- $\left.\mathrm{CH}_{2}\right), 1.43 \mathrm{ppm}\left(\mathrm{s}, 9 \mathrm{H}, \mathrm{COC}\left(\mathrm{CH}_{3}\right)_{3}\right)$; LC-MS (ESI+): $m / z 473.1[\mathrm{M}+\mathrm{H}]^{+}$(calcd. $m / z=472.1$ for $\mathrm{C}_{23} \mathrm{H}_{25} \mathrm{ClN}_{4} \mathrm{O}_{3} \mathrm{~S}$ ). 
4-(6-((3,4-Dichlorophenyl)carbamoyl)benzo[d]thiazol-2-yl)-1-Boc-piperazine (4d): Yield: $274 \mathrm{mg}(20 \%)$; off-white amorphous powder; $\mathrm{R}_{\mathrm{f}}($ EtOAc:Hex $=1: 2)=0,15 ;{ }^{1} \mathrm{H}$ NMR $\left(400 \mathrm{MHz}, \mathrm{CDCl}_{3}, 25^{\circ} \mathrm{C}, \mathrm{TMS}\right): \delta=8.21\left(\mathrm{~d}, J=1.8 \mathrm{~Hz}, 1 \mathrm{H}, \mathrm{Ar}-\mathrm{H}_{7}\right), 7.91(\mathrm{~d}, J=2.5 \mathrm{~Hz}, 1 \mathrm{H}$, Ar- $\left.H_{20}\right), 7.84(\mathrm{~s}, 1 \mathrm{H}, \mathrm{Ar}-\mathrm{NH}-\mathrm{COR}), 7.74\left(\mathrm{dd}, J_{1}=8.5 \mathrm{~Hz}, J_{2}=1.8 \mathrm{~Hz}, 1 \mathrm{H}, \mathrm{Ar}-H_{5}\right), 7.58(\mathrm{~d}$, $\left.J=8.5 \mathrm{~Hz}, 1 \mathrm{H}, \mathrm{Ar}-\mathrm{H}_{4}\right), 7.48\left(\mathrm{dd}, J_{1}=8.7, J_{2}=2.5 \mathrm{~Hz}, 1 \mathrm{H}, \mathrm{Ar}-\mathrm{H}_{24}\right), 7.42(\mathrm{~d}, J=8.7 \mathrm{~Hz}, 1 \mathrm{H}, \mathrm{Ar}-$ $\left.\mathrm{H}_{23}\right), 3.70-3.64\left(\mathrm{~m}, 6.5,3.6 \mathrm{~Hz}, 4 \mathrm{H}, 2 \times\right.$ piperazine- $\left.\mathrm{CH}_{2}\right), 3.63-3.58(\mathrm{~m}, 4 \mathrm{H}, 2 \times$ piperazine$\left.\mathrm{CH}_{2}\right), 1.50 \mathrm{ppm}\left(\mathrm{s}, 9 \mathrm{H}, \mathrm{COC}\left(\mathrm{CH}_{3}\right)_{3}\right)$; LC-MS (ESI+): $\mathrm{m} / z$ 506.9 $[\mathrm{M}+\mathrm{H}]^{+}$(calcd. $\mathrm{m} / \mathrm{z}=506,1$ for $\mathrm{C}_{23} \mathrm{H}_{24} \mathrm{Cl}_{2} \mathrm{~N}_{4} \mathrm{O}_{3} \mathrm{~S}$ ).

4-(6-((4-Fluorophenyl)carbamoyl)benzo[d]thiazol-2-yl)-1-Boc-piperazine (4e): Yield: $151 \mathrm{mg}(59 \%)$; off-white amorphous powder; $\mathrm{R}_{\mathrm{f}}($ EtOAc:Hex $=2: 1)=0.43 ;{ }^{1} \mathrm{H}$ NMR (400 MHz, [D $\mathrm{D}_{6}$ ]DMSO, $25^{\circ} \mathrm{C}$, TMS): $\delta=10.24(\mathrm{~s}, 1 \mathrm{H}, \mathrm{Ar}-\mathrm{NH}-\mathrm{COR}), 8.41(\mathrm{~d}, J=1.6 \mathrm{~Hz}$, $\left.1 \mathrm{H}, \mathrm{Ar}-H_{7}\right), 7.91\left(\mathrm{dd}, J_{1}=8.5 \mathrm{~Hz}, J_{2}=1.6 \mathrm{~Hz}, 1 \mathrm{H}, \mathrm{Ar}-H_{5}\right), 7.83-7.76(\mathrm{~m}, 2 \mathrm{H}, 2 \times \mathrm{Ar}-\mathrm{H})$, $7.55\left(\mathrm{~d}, J=8.5 \mathrm{~Hz}, 1 \mathrm{H}, \mathrm{Ar}-\mathrm{H}_{4}\right), 7.20(\mathrm{t}, J=8.9 \mathrm{~Hz}, 2 \mathrm{H}, 2 \times \mathrm{Ar}-H), 3.70-3.58(\mathrm{~m}, 4 \mathrm{H}, 2 \times$ piperazine- $\left.\mathrm{CH}_{2}\right), 3.56-3.46\left(\mathrm{~m}, 4 \mathrm{H}, 2 \times\right.$ piperazine- $\left.\mathrm{CH}_{2}\right), 1.44 \mathrm{ppm}\left(\mathrm{s}, 9 \mathrm{H}, \mathrm{COC}\left(\mathrm{CH}_{3}\right)_{3}\right)$; ${ }^{19} \mathrm{~F}$ NMR $\left(376 \mathrm{MHz},\left[\mathrm{D}_{6}\right] \mathrm{DMSO}, 25{ }^{\circ} \mathrm{C}, \mathrm{TMS}\right): \delta=-119.20 \mathrm{ppm} ;{ }^{13} \mathrm{C}\left(101 \mathrm{MHz},\left[\mathrm{D}_{6}\right] \mathrm{DMSO}\right.$, $25^{\circ} \mathrm{C}$, TMS): $\delta=170.4,165.4,158.6(\mathrm{~d}, J=239.9 \mathrm{~Hz}), 155.5,154.2,136.2,136.2,130.8,128.0$, 126.5, 122.5, 122.5, 121.7, 118.3, 115.7, 115.5, 79.8 (2C), 48.2 (2C), 28.5 ppm (3C); LC-MS (ESI+): $m / z 457.1[\mathrm{M}+\mathrm{H}]^{+}$(calcd. $m / z=456.2$ for $\mathrm{C}_{23} \mathrm{H}_{25} \mathrm{FN}_{4} \mathrm{O}_{3} \mathrm{~S}$ ).

4-(6-((4-Bromophenyl)carbamoyl)benzo[d]thiazol-2-yl)-1-Boc-piperazine (4f): Yield: $203 \mathrm{mg}(58 \%)$; yellow amorphous powder; $\mathrm{R}_{\mathrm{f}}($ EtOAc:Hex $=2: 1)=0.46 ;{ }^{1} \mathrm{H} \mathrm{NMR}(400 \mathrm{MHz}$, [D $\mathrm{D}_{6}$ ]DMSO, $\left.25^{\circ} \mathrm{C}, \mathrm{TMS}\right): \delta=10.30(\mathrm{~s}, 1 \mathrm{H}, \mathrm{Ar}-\mathrm{NH}-\mathrm{COR}), 8.40\left(\mathrm{~d}, J=1.9 \mathrm{~Hz}, 1 \mathrm{H}, \mathrm{Ar}-\mathrm{H}_{7}\right)$, $7.91\left(\mathrm{dd}, J_{1}=8.5 \mathrm{~Hz}, J_{2}=1.9 \mathrm{~Hz}, 1 \mathrm{H}, \mathrm{Ar}-\mathrm{H}_{5}\right), 7.81-7.73(\mathrm{~m}, 2 \mathrm{H}, 2 \times \mathrm{Ar}-H), 7.58-7.49(\mathrm{~m}, 3 \mathrm{H}$, $3 \times \mathrm{Ar}-\mathrm{H}), 3.68-3.57\left(\mathrm{~m}, 4 \mathrm{H}, 2 \times\right.$ piperazine- $\left.\mathrm{CH}_{2}\right), 3.56-3.45\left(\mathrm{~m}, 4 \mathrm{H}, 2 \times\right.$ piperazine- $\left.\mathrm{CH}_{2}\right)$, $1.43 \mathrm{ppm}\left(\mathrm{s}, 9 \mathrm{H}, \mathrm{COC}\left(\mathrm{CH}_{3}\right)_{3}\right)$; LC-MS (ESI+): $\mathrm{m} / z 571.4[\mathrm{M}+\mathrm{H}]^{+}$(calcd. $\mathrm{m} / z=516.1$ for $\left.\mathrm{C}_{23} \mathrm{H}_{25} \mathrm{BrN}_{4} \mathrm{O}_{3} \mathrm{~S}\right)$.

4-(6-((4-Iodophenyl)carbamoyl)benzo[d] thiazol-2-yl)-1-Boc-piperazine (4g): Yield: $77 \mathrm{mg}$ $(20 \%)$; yellow amorphous powder; $\mathrm{R}_{\mathrm{f}}(\mathrm{EtOAc:Hex}=2: 1)=0.58 ;{ }^{1} \mathrm{H}$ NMR $(400 \mathrm{MHz}$, [D $\mathrm{D}_{6}$ ]DMSO, $25{ }^{\circ} \mathrm{C}$, TMS): $\delta=10.27(\mathrm{~s}, 1 \mathrm{H}, \mathrm{Ar}-\mathrm{NH}-\mathrm{COR}), 8.40(\mathrm{~d}, J=1.9 \mathrm{~Hz}, 1 \mathrm{H}, \mathrm{Ar}-$ $\left.H_{7}\right), 7.90\left(\mathrm{dd}, J_{1}=8.5 \mathrm{~Hz}, J_{2}=1.9 \mathrm{~Hz}, 1 \mathrm{H}, \mathrm{Ar}-H_{5}\right), 7.72-7.66(\mathrm{~m}, 2 \mathrm{H}, 2 \times \mathrm{Ar}-\mathrm{H}), 7.66-7.60$ $(\mathrm{m}, 2 \mathrm{H}, 2 \times \mathrm{Ar}-\mathrm{H}), 7.54\left(\mathrm{~d}, \mathrm{~J}=8.5 \mathrm{~Hz}, 1 \mathrm{H}, \mathrm{Ar}-\mathrm{H}_{4}\right), 3.66-3.58\left(\mathrm{~m}, 4 \mathrm{H}, 2 \times\right.$ piperazine- $\left.\mathrm{CH}_{2}\right)$, 3.54-3.45 (m, $4 \mathrm{H}, 2 \times$ piperazine- $\left.\mathrm{CH}_{2}\right), 1.43 \mathrm{ppm}\left(\mathrm{s}, 9 \mathrm{H}, \mathrm{COC}\left(\mathrm{CH}_{3}\right)_{3}\right) ; \mathrm{LC}-\mathrm{MS}(\mathrm{ESI}+): \mathrm{m} / \mathrm{z}$ $565.0[\mathrm{M}+\mathrm{H}]^{+}$(calcd. $m / z=564.0$ for $\mathrm{C}_{23} \mathrm{H}_{25} \mathrm{IN}_{4} \mathrm{O}_{3} \mathrm{~S}$ ).

4-(6-((4-Isopropylphenyl)carbamoyl)benzo[d]thiazol-2-yl)-1-Boc-piperazine (4h): Yield: $151 \mathrm{mg}(50 \%)$; off-white amorphous powder; $\mathrm{R}_{\mathrm{f}}($ EtOAc:Hex $=2: 1)=0.63 ;{ }^{1} \mathrm{H}$ NMR (400 MHz, [D ${ }_{6}$ ]DMSO, $25^{\circ} \mathrm{C}$, TMS): $\delta=10.10$ (s, $1 \mathrm{H}$, Ar-NH-COR), 8.40 (d, $J=1.8 \mathrm{~Hz}$, $\left.1 \mathrm{H}, \mathrm{Ar}-\mathrm{H}_{7}\right), 7.91\left(\mathrm{dd}, J_{1}=8.5 \mathrm{~Hz}, J_{2}=1.8 \mathrm{~Hz}, 1 \mathrm{H}, \mathrm{Ar}-H_{5}\right), 7.68(\mathrm{~d}, J=8.5 \mathrm{~Hz}, 2 \mathrm{H}, 2 \times$ Ar$H), 7.54\left(\mathrm{~d}, J=8.5 \mathrm{~Hz}, 1 \mathrm{H}, \mathrm{Ar}-H_{4}\right), 7.21(\mathrm{~d}, J=8.5 \mathrm{~Hz}, 2 \mathrm{H}, 2 \times \mathrm{Ar}-H), 3.68-3.59(\mathrm{~m}$, $4 \mathrm{H}, 2 \times$ piperazine- $\left.\mathrm{CH}_{2}\right), 3.54-3.47\left(\mathrm{~m}, 4 \mathrm{H}, 2 \times\right.$ piperazine- $\left.\mathrm{CH}_{2}\right), 2.86\left(\mathrm{dt}, J_{1}=13.7 \mathrm{~Hz}\right.$, $\left.J_{2}=6.9 \mathrm{~Hz}, 1 \mathrm{H}, \mathrm{Ar}-\mathrm{CH}-\left(\mathrm{CH}_{3}\right)_{2}\right), 1.44\left(\mathrm{~s}, 9 \mathrm{H}, \mathrm{COC}\left(\mathrm{CH}_{3}\right)_{3}\right), 1.20 \mathrm{ppm}(\mathrm{d}, J=6.9 \mathrm{~Hz}, 6 \mathrm{H}$, Ar-CH-(CH$\left.)_{2}\right)$; LC-MS (ESI+): $m / z 481.1[\mathrm{M}+\mathrm{H}]^{+}$(calcd. $m / z=480.2$ for $\mathrm{C}_{26} \mathrm{H}_{32} \mathrm{~N}_{4} \mathrm{O}_{3} \mathrm{~S}$ ).

4-(6-((4-(Methylhydroxy)phenyl)carbamoyl)benzo[d]thiazol-2-yl)-1-Boc-piperazine (4i): Yield: $333 \mathrm{mg}(79 \%)$; yellow amorphous powder; $\mathrm{R}_{\mathrm{f}}($ EtOAc:Hex $=2: 1)=0.58 ;{ }^{1} \mathrm{H}$ NMR (400 MHz, [D D DMSO $\left._{2} 5^{\circ} \mathrm{C}, \mathrm{TMS}\right): \delta=10.08$ (s, $\left.1 \mathrm{H}, \mathrm{Ar}-\mathrm{NH}-\mathrm{COR}\right), 8.40(\mathrm{~d}, J=1.8 \mathrm{~Hz}, 1 \mathrm{H}$, Ar- $\left.H_{7}\right), 7.91\left(\mathrm{dd}, J_{1}=8.5 \mathrm{~Hz}, J_{2}=1.8 \mathrm{~Hz}, 1 \mathrm{H}, \mathrm{Ar}-\mathrm{H}_{5}\right), 7.73-7.64(\mathrm{~m}, 2 \mathrm{H}, 2 \times \mathrm{Ar}-\mathrm{H}), 7.53$ $\left(\mathrm{d}, J=8.5 \mathrm{~Hz}, 1 \mathrm{H}, \mathrm{Ar}-\mathrm{H}_{4}\right), 6.98-6.87(\mathrm{~m}, 2 \mathrm{H}, 2 \times \mathrm{Ar}-\mathrm{H}), 3.74\left(\mathrm{~s}, 3 \mathrm{H}, \mathrm{Ar}-\mathrm{O}-\mathrm{CH}_{3}\right), 3.66-3.58$ $\left(\mathrm{m}, 4 \mathrm{H}, 2 \times\right.$ piperazine- $\left.\mathrm{CH}_{2}\right), 3.54-3.46\left(\mathrm{~m}, 4 \mathrm{H}, 2 \times\right.$ piperazine- $\left.\mathrm{CH}_{2}\right), 1.44 \mathrm{ppm}(\mathrm{s}, 9 \mathrm{H}$, $\left.\mathrm{COC}\left(\mathrm{CH}_{3}\right)_{3}\right) ; \mathrm{LC}-\mathrm{MS}(\mathrm{ESI}+): \mathrm{m} / \mathrm{z} 469.2[\mathrm{M}+\mathrm{H}]^{+}$(calcd. $\mathrm{m} / \mathrm{z}=468.2$ for $\mathrm{C}_{24} \mathrm{H}_{28} \mathrm{~N}_{4} \mathrm{O}_{4} \mathrm{~S}$ ).

4-(6-(Benzylcarbamoyl)benzo[d]thiazol-2-yl)-1-Boc-piperazine (4j): Yield: $265 \mathrm{mg}(71 \%)$; yellow amorphous powder; $\mathrm{R}_{\mathrm{f}}($ EtOAc:Hex $=2: 1)=0.33 ;{ }^{1} \mathrm{H}$ NMR $\left(400 \mathrm{MHz},\left[\mathrm{D}_{6}\right] \mathrm{DMSO}\right.$, $25^{\circ} \mathrm{C}$, TMS): $\delta=8.96\left(\mathrm{t}, J=6.0 \mathrm{~Hz}, 1 \mathrm{H}, \mathrm{Ar}-\mathrm{CH}_{2}-\mathrm{NH}-\mathrm{COR}\right), 8.32\left(\mathrm{~d}, J=1.8 \mathrm{~Hz}, 1 \mathrm{H}, \mathrm{Ar}-\mathrm{H}_{7}\right)$, $7.84\left(\mathrm{dd}, J_{1}=8.5, J_{2}=1.8 \mathrm{~Hz}, 1 \mathrm{H}, \mathrm{Ar}-H_{5}\right), 7.49\left(\mathrm{~d}, J=8.5 \mathrm{~Hz}, 1 \mathrm{H}, \mathrm{Ar}-H_{4}\right), 7.35-7.29(\mathrm{~m}, 4 \mathrm{H}$, $4 \times \operatorname{Ar}-H), 7.27-7.21(\mathrm{~m}, 1 \mathrm{H}, \mathrm{Ar}-\mathrm{H}), 4.48\left(\mathrm{~d}, J=6.0 \mathrm{~Hz}, 2 \mathrm{H}, \mathrm{Ar}-\mathrm{CH}_{2}-\mathrm{NHCO}\right), 3.61(\mathrm{~m}, 4 \mathrm{H}$, 
$2 \times$ piperazine- $\left.\mathrm{CH}_{2}\right), 3.54-3.44\left(\mathrm{~m}, 4 \mathrm{H}, 2 \times\right.$ piperazine- $\left.\mathrm{CH}_{2}\right), 1.43 \mathrm{ppm}\left(\mathrm{s}, 9 \mathrm{H}, \mathrm{COC}\left(\mathrm{CH}_{3}\right)_{3}\right)$; LC-MS (ESI+): $m / z 452.7[\mathrm{M}+\mathrm{H}]^{+}$(calcd. $m / z=452.2$ for $\mathrm{C}_{24} \mathrm{H}_{26} \mathrm{Cl}_{2} \mathrm{~N}_{4} \mathrm{O}_{3} \mathrm{~S}$ ).

4-(6-((3-Chlorobenzyl)carbamoyl)benzo[d]thiazol-2-yl)1-Boc-piperazine (4k): Yield: $196 \mathrm{mg}(64 \%)$; white amorphous powder; $\mathrm{R}_{\mathrm{f}}($ EtOAc:Hex $=1: 1)=0.19 ;{ }^{1} \mathrm{H}$ NMR $(400 \mathrm{MHz}$, [D $\mathrm{D}_{6}$ ]DMSO, $25^{\circ} \mathrm{C}$, TMS): $\delta=9.01\left(\mathrm{t}, J=6.0 \mathrm{~Hz}, 1 \mathrm{H}, \mathrm{CH}_{2}-\mathrm{NH}-\mathrm{COR}\right), 8.33(\mathrm{~d}, J=1.8 \mathrm{~Hz}$, $\left.1 \mathrm{H}, \mathrm{Ar}-H_{7}\right), 7.84\left(\mathrm{dd}, J_{1}=8.5 \mathrm{~Hz}, J_{2}=1.8 \mathrm{~Hz}, 1 \mathrm{H}, \mathrm{Ar}-H_{5}\right), 7.50\left(\mathrm{~d}, J=8.5 \mathrm{~Hz}, 1 \mathrm{H}, \mathrm{Ar}-\mathrm{H}_{4}\right)$, 7.39-7.34 (m, 2H, $2 \times$ Ar- $H), 7.33-7.27(\mathrm{~m}, 2 \mathrm{H}, 2 \times \mathrm{Ar}-\mathrm{H}), 4.48(\mathrm{~d}, J=6.0 \mathrm{~Hz}, 2 \mathrm{H}, \mathrm{RCO}-\mathrm{NH}-$ $\left.\mathrm{CH}_{2}-\mathrm{Ph}\right), 3.64-3.58\left(\mathrm{~m}, 4 \mathrm{H}, 2 \times\right.$ piperazine- $\left.\mathrm{CH}_{2}\right), 3.55-3.44\left(\mathrm{~m}, 4 \mathrm{H}, 2 \times\right.$ piperazine- $\left.\mathrm{CH}_{2}\right)$, $1,43 \mathrm{ppm}\left(\mathrm{s}, 9 \mathrm{H}, \mathrm{COC}\left(\mathrm{CH}_{3}\right)_{3}\right)$; LC-MS (ESI+): $\mathrm{m} / z 487.1[\mathrm{M}+\mathrm{H}]^{+}$(calcd. $\mathrm{m} / z=486.1$ for $\mathrm{C}_{24} \mathrm{H}_{27} \mathrm{ClN}_{4} \mathrm{O}_{3} \mathrm{~S}$ ).

4-(6-((4-Chlorobenzyl)carbamoyl)benzo[d]thiazol-2-yl)-1-Boc-piperazine (41): Yield: $200 \mathrm{mg}(65 \%)$; yellow amorphous powder; $\mathrm{R}_{\mathrm{f}}($ EtOAc:Hex $=1: 1)=0.19 ;{ }^{1} \mathrm{H} \mathrm{NMR}(400 \mathrm{MHz}$, [D $\mathrm{D}_{6}$ ]DMSO, $\left.25{ }^{\circ} \mathrm{C}, \mathrm{TMS}\right): \delta=8.99\left(\mathrm{t}, J=5.9 \mathrm{~Hz}, 1 \mathrm{H}, \mathrm{CH}_{2}-\mathrm{NH}-\mathrm{COR}\right), 8.32(\mathrm{~d}, J=1.7 \mathrm{~Hz}$, $\left.1 \mathrm{H}, \mathrm{Ar}-\mathrm{H}_{7}\right), 7.83\left(\mathrm{dd}, J_{1}=8.5 \mathrm{~Hz}, J_{2}=1.7 \mathrm{~Hz}, 1 \mathrm{H}, \mathrm{Ar}-H_{5}\right), 7.49\left(\mathrm{~d}, J=8.5 \mathrm{~Hz}, 1 \mathrm{H}, \mathrm{Ar}-\mathrm{H}_{4}\right)$, 7.42-7.31 (m, 4H, $4 \times \mathrm{Ar}-\mathrm{H}), 4.46\left(\mathrm{~d}, J=5.9 \mathrm{~Hz}, 2 \mathrm{H}, \mathrm{RCO}-\mathrm{NH}-\mathrm{CH}_{2}-\mathrm{Ph}\right), 3.66-3.56(\mathrm{~m}, 4 \mathrm{H}$, $2 \times$ piperazine- $\left.\mathrm{CH}_{2}\right), 3.53-3.43\left(\mathrm{~m}, 4 \mathrm{H}, 2 \times\right.$ piperazine- $\left.\mathrm{CH}_{2}\right), 1.43 \mathrm{ppm}\left(\mathrm{s}, 9 \mathrm{H}, \mathrm{COC}\left(\mathrm{CH}_{3}\right)_{3}\right)$; ${ }^{13} \mathrm{C}\left(101 \mathrm{MHz},\left[\mathrm{D}_{6}\right.\right.$ ]DMSO, $25^{\circ} \mathrm{C}$, TMS): $\delta=170.2,166.3,155.2,154.2,139.4,131.7,130.8$, 129.6 (2C), 128.7 (2C), 127.6, 126.0, 121.3, 118.3, 79.8, 48.2 (2C), 42.5 (2C), 28.5 ppm (3C); LC-MS (ESI+): $m / z 487.4[\mathrm{M}+\mathrm{H}]^{+}$(calcd. $m / z=486.1$ for $\mathrm{C}_{24} \mathrm{H}_{27} \mathrm{ClN}_{4} \mathrm{O}_{3} \mathrm{~S}$ ).

4-(6-((Indane-1-yl)carbamoyl)benzo[d]thiazol-2-yl)-1-Boc-piperazine (4m): Yield: $165 \mathrm{mg}$ $(63 \%)$; white amorphous powder; $\mathrm{R}_{\mathrm{f}}(\mathrm{EtOAc:Hex}=2: 1)=0.39 ;{ }^{1} \mathrm{H}$ NMR $\left(400 \mathrm{MHz},\left[\mathrm{D}_{6}\right] \mathrm{DMSO}\right.$, $25^{\circ} \mathrm{C}$, TMS): $\delta=8.68$ (d, $J=8.3 \mathrm{~Hz}, 1 \mathrm{H}, \mathrm{CH}-\mathrm{N} H$-COR $), 8.35$ (d, J = 1.6 Hz, $\left.1 \mathrm{H}, \mathrm{Ar}-\mathrm{H}\right), 7.87$ $\left(\mathrm{dd}, J_{1}=8.5 \mathrm{~Hz}, J_{2}=1.6 \mathrm{~Hz}, 1 \mathrm{H}, \mathrm{Ar}-H\right), 7.48(\mathrm{~d}, J=8.5 \mathrm{~Hz}, 1 \mathrm{H}, \mathrm{Ar}-H), 7.32-7.13(\mathrm{~m}, 4 \mathrm{H}$, $4 \times \mathrm{Ar}-H), 5.56\left(\mathrm{dd}, J_{1}=16.1 \mathrm{~Hz}, J_{2}=8.3 \mathrm{~Hz}, 1 \mathrm{H}\right.$, indane- $\left.H\right), 3.66-3.55(\mathrm{~m}, 1 \mathrm{H}$, indane- $H)$, 3.53-3.46 $\left(\mathrm{m}, 4 \mathrm{H}, 2 \times\right.$ piperazine- $\left.\mathrm{CH}_{2}\right), 3.05-2.95\left(\mathrm{~m}, 4 \mathrm{H}, 2 \times\right.$ piperazine- $\left.\mathrm{CH}_{2}\right), 2.91-2.79$ $(\mathrm{m}, 1 \mathrm{H}$, indane- $H), 2.05-1.92 \mathrm{ppm}(\mathrm{m}, 1 \mathrm{H}$, indane- $H)$, not visible $(1 \mathrm{H}$, indane- $H)$; LC-MS (ESI+): $m / z 479.1[\mathrm{M}+\mathrm{H}]^{+}$(calcd. $m / z=478.2$ for $\mathrm{C}_{26} \mathrm{H}_{30} \mathrm{~N}_{4} \mathrm{O}_{3} \mathrm{~S}$ ).

General procedure for acidolysis used for the synthesis of compounds 5a-m, 9a-j and 14

4-Boc-protected benzothiazole (1 equiv) was dissolved in dichloromethane. Trifluoroacetic acid ( 25 equiv) was added, and the reaction mixture was stirred overnight at room temperature. Afterwards, the reaction mixture was diluted with dichloromethane to $25 \mathrm{~mL}$ and washed with $1 \mathrm{M} \mathrm{NaOH}(3 \times 25 \mathrm{~mL})$ and saturated $\mathrm{NaCl}(25 \mathrm{~mL})$. The organic phase was dried over $\mathrm{Na}_{2} \mathrm{SO}_{4}$, filtered, and the solvent was evaporated under reduced pressure.

4-(6-(Phenylcarbamoyl)benzo[d]thiazol-2-yl)piperazine (5a): Yield: $91 \mathrm{mg}(74 \%)$; offwhite amorphous powder; $\mathrm{R}_{\mathrm{f}}(\mathrm{DCM}: \mathrm{MeOH}=9: 1)=0.0 ;{ }^{1} \mathrm{H}$ NMR $\left(400 \mathrm{MHz},\left[\mathrm{D}_{6}\right] \mathrm{DMSO}\right.$, $\left.25^{\circ} \mathrm{C}, \mathrm{TMS}\right): \delta=10.16(\mathrm{~s}, 1 \mathrm{H}, \mathrm{Ar}-\mathrm{N} H-\mathrm{COR}), 8.38\left(\mathrm{~d}, J=1.8 \mathrm{~Hz}, 1 \mathrm{H}, \mathrm{Ar}-H_{7}\right), 7.90(\mathrm{dd}$, $\left.J_{1}=8.5 \mathrm{~Hz}, J_{2}=1.8 \mathrm{~Hz}, 1 \mathrm{H}, \mathrm{Ar}-H_{5}\right), 7.82-7.75(\mathrm{~m}, 2 \mathrm{H}, 2 \times \mathrm{Ar}-\mathrm{H}), 7.51(\mathrm{~d}, J=8.5 \mathrm{~Hz}, 1 \mathrm{H}, \mathrm{Ar}-$ $\left.H_{4}\right), 7.39-7.30(\mathrm{~m}, 2 \mathrm{H}, 2 \times \mathrm{Ar}-H), 7.13-7.04(\mathrm{~m}, 1 \mathrm{H}, \mathrm{Ar}-\mathrm{H}), 3.58-3.48(\mathrm{~m}, 4 \mathrm{H}, 2 \times$ piperazine$\left.\mathrm{CH}_{2}\right), 2.87-2.76 \mathrm{ppm}\left(\mathrm{m}, 4 \mathrm{H}, 2 \times\right.$ piperazine- $\left.\mathrm{CH}_{2}\right) ;{ }^{13} \mathrm{C}\left(101 \mathrm{MHz},\left[\mathrm{D}_{6}\right] \mathrm{DMSO}, 25^{\circ} \mathrm{C}\right.$, TMS $)$ : $\delta=170.6,165.5,155.7,139.9,130.6,129.0(2 \mathrm{C}), 127.8,126.5,123.9,121.5,120.7$ (2C), 118.1, 49.9 (2C), 45.5 ppm (2C); HRMS (ESI+) $m / z$ calcd. calcd. for $\mathrm{C}_{18} \mathrm{H}_{18} \mathrm{~N}_{4} \mathrm{OS}+\mathrm{H}^{+}: 339.1274$ $[\mathrm{M}+\mathrm{H}]^{+}$: found $339.1269 ;$ HPLC: $\mathrm{t}_{\mathrm{r}}=2.27 \mathrm{~min}(97.4 \%$ at $254 \mathrm{~nm})$.

4-(6-((3-Chlorophenyl)carbamoyl)benzo[d]thiazol-2-yl)piperazine (5b): Yield: $43 \mathrm{mg}$ (91\%); off-white amorphous powder; $\mathrm{R}_{\mathrm{f}}(\mathrm{DCM}: \mathrm{MeOH}=9: 1)=0.07 ;{ }^{1} \mathrm{H} \mathrm{NMR}(400 \mathrm{MHz}$, [D $\mathrm{D}_{6}$ ]DMSO, $\left.25^{\circ} \mathrm{C}, \mathrm{TMS}\right): \delta=10.32(\mathrm{~s}, 1 \mathrm{H}, \mathrm{Ar}-\mathrm{NH}-\mathrm{COR}), 8.38\left(\mathrm{~d}, J=1.9 \mathrm{~Hz}, 1 \mathrm{H}, \mathrm{Ar}-\mathrm{H}_{7}\right)$, $7.98(\mathrm{t}, J=2.0 \mathrm{~Hz}, 1 \mathrm{H}, \mathrm{Ar}-H), 7.90\left(\mathrm{dd}, J_{1}=8.5 \mathrm{~Hz}, J_{2}=1.9 \mathrm{~Hz}, 1 \mathrm{H}, \mathrm{Ar}-H_{5}\right), 7.71(\mathrm{ddd}$, $\left.J_{1}=8.1 \mathrm{~Hz}, J_{2}=2.0 \mathrm{~Hz}, J_{3}=0.9 \mathrm{~Hz}, 1 \mathrm{H}, \operatorname{Ar}-H\right), 7.52\left(\mathrm{~d}, J=8.5 \mathrm{~Hz}, 1 \mathrm{H}, \mathrm{Ar}-H_{4}\right), 7.38(\mathrm{t}$, $J=8.1 \mathrm{~Hz}, 1 \mathrm{H}, \mathrm{Ar}-H), 7.14\left(\mathrm{ddd}, J_{1}=8.1 \mathrm{~Hz}, J_{2}=2.0 \mathrm{~Hz}, J_{3}=0.9 \mathrm{~Hz}, 1 \mathrm{H}, \mathrm{Ar}-H\right), 3.58-3.51$ $\left(\mathrm{m}, 4 \mathrm{H}, 2 \times\right.$ piperazine- $\left.\mathrm{CH}_{2}\right), 2.85-2.79 \mathrm{ppm}\left(\mathrm{m}, 4 \mathrm{H}, 2 \times\right.$ piperazine- $\left.\mathrm{CH}_{2}\right)$, not visible $(\mathrm{NH})$; ${ }^{13} \mathrm{C}\left(101 \mathrm{MHz},\left[\mathrm{D}_{6}\right] \mathrm{DMSO}, 25{ }^{\circ} \mathrm{C}, \mathrm{TMS}\right): \delta=170.7,165.8,155.9,141.4,133.4,130.8,130.6$, 127.3, 126.6, 123.5, 121.7, 120.0, 119.0, 118.1, 49.9 (2C), 45.5 (2C) ppm; HRMS (ESI+) $m / z$ 
calcd. calcd. for $\mathrm{C}_{18} \mathrm{H}_{17} \mathrm{ClN}_{4} \mathrm{OS}+\mathrm{H}^{+}$: $373.0884[\mathrm{M}+\mathrm{H}]^{+}$: found 373.0880; HPLC: $\mathrm{t}_{\mathrm{r}}=5.31$ $\min (95.5 \%$ at $254 \mathrm{~nm})$.

4-(6-((4-Chlorophenyl)carbamoyl)benzo[d]thiazol-2-yl)piperazine (5c): Yield: $61 \mathrm{mg}(31 \%)$; white powder; $\mathrm{R}_{\mathrm{f}}(\mathrm{DCM}: \mathrm{MeOH}=9: 1)=0.09 ;{ }^{1} \mathrm{H}$ NMR $\left(400 \mathrm{MHz},\left[\mathrm{D}_{6}\right] \mathrm{DMSO}, 2{ }^{\circ} \mathrm{C}\right.$, TMS $)$ : $\delta=10.29(\mathrm{~s}, 1 \mathrm{H}, \mathrm{Ar}-\mathrm{NH}-\mathrm{COR}), 8.38\left(\mathrm{~d}, J=1.8 \mathrm{~Hz}, 1 \mathrm{H}, \mathrm{Ar}-H_{7}\right), 7.89\left(\mathrm{dd}, J_{1}=8.5, J_{2}=1.8 \mathrm{~Hz}\right.$, $\left.1 \mathrm{H}, \mathrm{Ar}-\mathrm{H}_{5}\right), 7.85-7.78(\mathrm{~m}, 2 \mathrm{H}, 2 \times \mathrm{Ar}-\mathrm{H}), 7.51\left(\mathrm{~d}, J=8.5 \mathrm{~Hz}, 1 \mathrm{H}, \mathrm{Ar}-\mathrm{H}_{4}\right), 7.44-7.37(\mathrm{~m}, 2 \mathrm{H}$, $2 \times \operatorname{Ar}-\mathrm{H}), 3.57-3.50\left(\mathrm{~m}, 4 \mathrm{H}, 2 \times\right.$ piperazine- $\left.\mathrm{CH}_{2}\right), 2.84-2.78 \mathrm{ppm}(\mathrm{m}, 4 \mathrm{H}, 2 \times$ piperazine$\left.\mathrm{CH}_{2}\right)$, not visible $(\mathrm{NH}) ;{ }^{13} \mathrm{C}\left(101 \mathrm{MHz},\left[\mathrm{D}_{6}\right] \mathrm{DMSO}, 25^{\circ} \mathrm{C}, \mathrm{TMS}\right): \delta=170.7,165.6,155.8$, $138.9,130.6,129.0(2 \mathrm{C}), 127.5,127.4,126.6,122.2$ (2C), 121.6, 118.1, 49.9 (2C), $45.5 \mathrm{ppm}(2 \mathrm{C})$; HRMS (ESI+) $m / z$ calcd. calcd. for $\mathrm{C}_{18} \mathrm{H}_{17} \mathrm{ClN}_{4} \mathrm{OS}+\mathrm{H}^{+}$: $373.0884[M+\mathrm{H}]^{+}$: found 373.0878; HPLC: $\mathrm{t}_{\mathrm{r}}=5.27 \mathrm{~min}(97.2 \%$ at $254 \mathrm{~nm})$.

4-(6-((3,4-Dichlorophenyl)carbamoyl)benzo[d]thiazol-2-yl)piperazine (5d): Yield: $118 \mathrm{mg}$ (68\%); off-white amorphous powder; $\mathrm{R}_{\mathrm{f}}(\mathrm{EtOAc}: \mathrm{Hex}=1: 1)=0 ;{ }^{1} \mathrm{H} \mathrm{NMR}\left(400 \mathrm{MHz}, \mathrm{CDCl}_{3}\right.$, $25^{\circ} \mathrm{C}$, TMS): $\delta=8.20\left(\mathrm{~d}, J=1.9 \mathrm{~Hz}, 1 \mathrm{H}, \mathrm{Ar}-H_{7}\right), 7.90\left(\mathrm{~d}, J=2.4 \mathrm{~Hz}, 1 \mathrm{H}, \mathrm{Ar}-\mathrm{H}_{20}\right), 7.79(\mathrm{~s}$, $1 \mathrm{H}, \mathrm{Ar}-\mathrm{NH}$-COR), $7.73\left(\mathrm{dd}, J_{1}=8.5 \mathrm{~Hz}, J_{2}=1.9 \mathrm{~Hz}, 1 \mathrm{H}, \mathrm{Ar}-H_{5}\right), 7.57(\mathrm{~d}, J=8.5 \mathrm{~Hz}, 1 \mathrm{H}$, Ar- $\left.H_{4}\right), 7.48\left(\mathrm{dd}, J_{1}=8.7 \mathrm{~Hz}, J_{2}=2.4 \mathrm{~Hz}, 1 \mathrm{H}, \mathrm{Ar}-\mathrm{H}_{24}\right), 7.42\left(\mathrm{~d}, J=8.7 \mathrm{~Hz}, 1 \mathrm{H}, \mathrm{Ar}-\mathrm{H}_{23}\right)$, 3.70-3.65 $\left(\mathrm{m}, 4 \mathrm{H}, 2 \times\right.$ piperazine- $\left.\mathrm{CH}_{2}\right), 3.06-2.99 \mathrm{ppm}\left(\mathrm{m}, 4 \mathrm{H}, 2 \times\right.$ piperazine- $\left.\mathrm{CH}_{2}\right)$, not visible (NH); ${ }^{13} \mathrm{C}$ NMR (101 MHz, [D ${ }_{6}$ ]DMSO, $\left.25^{\circ} \mathrm{C}, \mathrm{TMS}\right): \delta=170.8,165.8,156.0,140.1$, 131.3, 131.0, 130.7, 127.1, 126.7, 125.2, 121.7, 121.7, 120.6, 118.1, 49.9 (2C), 45.5 ppm (2C); HRMS (ESI+) $m / z$ calcd. calcd. for $\mathrm{C}_{18} \mathrm{H}_{16} \mathrm{Cl}_{2} \mathrm{~N}_{4} \mathrm{OS}+\mathrm{H}^{+}$: $407.0495[\mathrm{M}+\mathrm{H}]^{+}$: found 407.0487; HPLC: $\mathrm{t}_{\mathrm{r}}=6.57 \mathrm{~min}(95.3 \%$ at $254 \mathrm{~nm})$.

4-(6-((4-Fluorophenyl)carbamoyl)benzo[d]thiazol-2-yl)piperazine (5e): Yield: $74 \mathrm{mg}(95 \%)$; white amorphous powder; $\mathrm{R}_{\mathrm{f}}(\mathrm{DCM}: \mathrm{MeOH}=9: 1)=0.05 ;{ }^{1} \mathrm{H} \mathrm{NMR}\left(400 \mathrm{MHz},\left[\mathrm{D}_{6}\right] \mathrm{DMSO}\right.$, $\left.25^{\circ} \mathrm{C}, \mathrm{TMS}\right): \delta=10.22(\mathrm{~s}, 1 \mathrm{H}, \mathrm{Ar}-\mathrm{NH}-\mathrm{COR}), 8.38\left(\mathrm{~d}, J=1.8 \mathrm{~Hz}, 1 \mathrm{H}, \mathrm{Ar}-\mathrm{H}_{7}\right), 7.90(\mathrm{dd}$, $\left.J_{1}=8.5 \mathrm{~Hz}, J_{2}=1.8 \mathrm{~Hz}, 1 \mathrm{H}, \mathrm{Ar}-H_{5}\right), 7.84-7.74(\mathrm{~m}, 2 \mathrm{H}, 2 \times \mathrm{Ar}-\mathrm{H}), 7.52(\mathrm{~d}, J=8.5 \mathrm{~Hz}, 1 \mathrm{H}$, Ar- $\left.H_{4}\right), 7.24-7.14(\mathrm{~m}, 2 \mathrm{H}, 2 \times$ Ar- $H), 3.59-3.50\left(\mathrm{~m}, 4 \mathrm{H}, 2 \times\right.$ piperazine- $\left.\mathrm{CH}_{2}\right), 2.83 \mathrm{ppm}(\mathrm{m}$, $4.3 \mathrm{~Hz}, 4 \mathrm{H}, 2 \times$ piperazine- $\left.\mathrm{CH}_{2}\right)$, not visible $(\mathrm{NH}) ;{ }^{19} \mathrm{~F}$ NMR $\left(376 \mathrm{MHz},\left[\mathrm{D}_{6}\right] \mathrm{DMSO}, 25^{\circ} \mathrm{C}\right.$, TMS): $\delta=-119.26 \mathrm{ppm} ;{ }^{13} \mathrm{C}\left(101 \mathrm{MHz},\left[\mathrm{D}_{6}\right] \mathrm{DMSO}, 25^{\circ} \mathrm{C}, \mathrm{TMS}\right): \delta=170.6,165.4,158.60(\mathrm{~d}$, $J=239.8 \mathrm{~Hz}), 155.7,136.2(\mathrm{~d}, J=2.6 \mathrm{~Hz}), 130.6,127.6,126.5,122.5,122.4,121.5,118.1,115.7$, $115.5,49.9$ (2C), 45.5 ppm (2C); HRMS (ESI+) $m / z$ calcd. calcd. for $\mathrm{C}_{18} \mathrm{H}_{17} \mathrm{FN}_{4} \mathrm{OS}+\mathrm{H}^{+}$: $357.1180[\mathrm{M}+\mathrm{H}]^{+}$: found 357.1173; HPLC: $\mathrm{t}_{\mathrm{r}}=3.27 \mathrm{~min}(99.0 \%$ at $254 \mathrm{~nm})$.

4-(6-((4-Bromophenyl)carbamoyl)benzo[d]thiazol-2-yl)piperazine (5f): Yield: $70 \mathrm{mg}(72 \%)$; off-white amorphous powder; $\mathrm{R}_{\mathrm{f}}(\mathrm{DCM}: \mathrm{MeOH}=9: 1)=0.05 ;{ }^{1} \mathrm{H}$ NMR $\left(400 \mathrm{MHz},\left[\mathrm{D}_{6}\right] \mathrm{DMSO}\right.$, $25^{\circ} \mathrm{C}$, TMS): $\delta=10.28$ (s, $\left.1 \mathrm{H}, \mathrm{Ar}-\mathrm{NH}-\mathrm{COR}\right), 8.38\left(\mathrm{~d}, J=1.8 \mathrm{~Hz}, 1 \mathrm{H}, \mathrm{Ar}-H_{7}\right), 7.89(\mathrm{dd}$, $\left.J_{1}=8.5 \mathrm{~Hz}, J_{2}=1.8 \mathrm{~Hz}, 1 \mathrm{H}, \mathrm{Ar}-H_{5}\right), 7.79-7.73(\mathrm{~m}, 2 \mathrm{H}, 2 \times \mathrm{Ar}-H), 7.56-7.47(\mathrm{~m}, 3 \mathrm{H}, 3 \times \mathrm{Ar}-$ $H), 3.59-3.48\left(\mathrm{~m}, 4 \mathrm{H}, 2 \times\right.$ piperazine- $\left.\mathrm{CH}_{2}\right), 2.86-2.77 \mathrm{ppm}\left(\mathrm{m}, 4 \mathrm{H}, 2 \times\right.$ piperazine- $\left.\mathrm{CH}_{2}\right)$, not visible $(\mathrm{NH}) ;{ }^{13} \mathrm{C}\left(101 \mathrm{MHz},\left[\mathrm{D}_{6}\right.\right.$ ]DMSO, $25{ }^{\circ} \mathrm{C}$, TMS $): \delta=170.7,165.6,155.8,139.3$, 131.9 (2C), 130.6, 127.5, 126.6, 122.6 (2C), 121.6, 118.1, 115.5, 49.9 (2C), 45.5 ppm (2C); HRMS (ESI+) $\mathrm{m} / z$ calcd. calcd. for $\mathrm{C}_{18} \mathrm{H}_{17} \mathrm{BrN}_{4} \mathrm{OS}+\mathrm{H}^{+}: 417.0379[\mathrm{M}+\mathrm{H}]^{+}$: found 417.0372; HPLC: $\mathrm{t}_{\mathrm{r}}=5.45 \mathrm{~min}(96.5 \%$ at $254 \mathrm{~nm})$.

4-(6-((4-Iodophenyl)carbamoyl)benzo[d]thiazol-2-yl)piperazine (5g): Yield: $44 \mathrm{mg}(83 \%)$; light yellow amorphous powder; $\mathrm{R}_{\mathrm{f}}(\mathrm{DCM}: \mathrm{MeOH}=9: 1)=0.09 ;{ }^{1} \mathrm{H}$ NMR $(400 \mathrm{MHz}$, [D $\mathrm{D}_{6}$ ]DMSO, $\left.25^{\circ} \mathrm{C}, \mathrm{TMS}\right): \delta=10.25(\mathrm{~s}, 1 \mathrm{H}, \mathrm{Ar}-\mathrm{NH}-\mathrm{COR}), 8.37(\mathrm{~s}, 1 \mathrm{H}, \mathrm{Ar}-H), 7.89(\mathrm{~d}, J=8.5 \mathrm{~Hz}$, $1 \mathrm{H}, \mathrm{Ar}-H), 7.71-7.60(\mathrm{~m}, 4 \mathrm{H}, 4 \times \mathrm{Ar}-H), 7.50(\mathrm{~d}, J=8.1 \mathrm{~Hz}, 1 \mathrm{H}, \mathrm{Ar}-H), 3.57-3.51(\mathrm{~m}, 4 \mathrm{H}$, $2 \times$ piperazine- $\left.\mathrm{CH}_{2}\right), 2.84-2.79 \mathrm{ppm}\left(\mathrm{m}, 4 \mathrm{H}, 2 \times\right.$ piperazine- $\left.\mathrm{CH}_{2}\right)$, not visible $(\mathrm{NH}) ;{ }^{13} \mathrm{C}$ (101 MHz, [D ${ }_{6}$ ]DMSO, $\left.25^{\circ} \mathrm{C}, \mathrm{TMS}\right): \delta=170.6,165.6,155.8,139.8,137.7(2 \mathrm{C}), 130.6,127.5$, 126.6, 122.8 (2C), 121.6, 118.1, 87.4, 49.8 (2C), 45.5 ppm (2C); HRMS (ESI+) $\mathrm{m} / z$ calcd. for $\mathrm{C}_{18} \mathrm{H}_{17} \mathrm{IN}_{4} \mathrm{OS}+\mathrm{H}^{+}$: $465.0234[M+\mathrm{H}]^{+}$: found 465.0241 ; HPLC: $\mathrm{t}_{\mathrm{r}}=5.03 \mathrm{~min}(98.7 \%$ at $254 \mathrm{~nm})$.

4-(6-((4-Isopropylphenyl)carbamoyl)benzo[d]thiazol-2-yl)piperazine (5h): Yield: $44 \mathrm{mg}$ $(80 \%)$; off-white amorphous powder; $\mathrm{R}_{\mathrm{f}}(\mathrm{DCM}: \mathrm{MeOH}=9: 1)=0.06 ;{ }^{1} \mathrm{H} \mathrm{NMR}(400 \mathrm{MHz}$, $\left.\left[\mathrm{D}_{6}\right] \mathrm{DMSO}, 25^{\circ} \mathrm{C}, \mathrm{TMS}\right): \delta=10.08(\mathrm{~s}, 1 \mathrm{H}, \mathrm{Ar}-\mathrm{NH}-\mathrm{COR}), 8.37\left(\mathrm{~d}, J=1.8 \mathrm{~Hz}, 1 \mathrm{H}, \mathrm{Ar}-\mathrm{H}_{7}\right)$, 
$7.89\left(\mathrm{dd}, J_{1}=8.5 \mathrm{~Hz}, J_{2}=1.8 \mathrm{~Hz}, 1 \mathrm{H}, \mathrm{Ar}-H_{5}\right), 7.68(\mathrm{~d}, J=8.6 \mathrm{~Hz}, 2 \mathrm{H}, 2 \times \mathrm{Ar}-H), 7.50(\mathrm{~d}$, $\left.J=8.5 \mathrm{~Hz}, 1 \mathrm{H}, \mathrm{Ar}-\mathrm{H}_{4}\right), 7.21(\mathrm{~d}, J=8.6 \mathrm{~Hz}, 2 \mathrm{H}, 2 \times \mathrm{Ar}-\mathrm{H}), 3.58-3.47(\mathrm{~m}, 4 \mathrm{H}, 2 \times$ piperazine$\left.\mathrm{CH}_{2}\right), 2.90-2.78\left(\mathrm{~m}, 5 \mathrm{H}, \mathrm{Ar}-\mathrm{CH}-\left(\mathrm{CH}_{3}\right)_{2}+2 \times\right.$ piperazine- $\left.\mathrm{CH}_{2}\right), 1.20 \mathrm{ppm}(\mathrm{d}, J=6.9 \mathrm{~Hz}, 6 \mathrm{H}$, Ar-CH- $\left.\left(\mathrm{CH}_{3}\right)_{2}\right) ;{ }^{13} \mathrm{C}\left(101 \mathrm{MHz},\left[\mathrm{D}_{6}\right] \mathrm{DMSO}, 25{ }^{\circ} \mathrm{C}, \mathrm{TMS}\right): \delta=170.5,165.3,155.6,143.9,137.6$, $130.5,127.9,126.7$ (2C), 126.5, 121.5, 120.8 (2C), 118.0, 49.9 (2C), 45.5 (2C), 33.4, 24.5 ppm (2C); HRMS (ESI+) $m / z$ calcd. for $\mathrm{C}_{21} \mathrm{H}_{24} \mathrm{~N}_{4} \mathrm{OS}+\mathrm{H}^{+}$: $381.1744[\mathrm{M}+\mathrm{H}]^{+}$: found 381.1737; HPLC: $\mathrm{t}_{\mathrm{r}}=5.12 \mathrm{~min}(99.0 \%$ at $254 \mathrm{~nm})$.

4-(6-((4-(Methylhydroxy)phenyl)carbamoyl)benzo[d]thiazol-2-yl)piperazine (5i): Yield: $43 \mathrm{mg}$ (91\%); off-white amorphous powder; $\mathrm{R}_{\mathrm{f}}(\mathrm{DCM}: \mathrm{MeOH}=9: 1)=0.08$; ${ }^{1} \mathrm{H}$ NMR (400 MHz, [D $\left.]_{\mathrm{DMSO}} 25^{\circ} \mathrm{C}, \mathrm{TMS}\right): \delta=10.04$ (s, 1H, Ar-NH-COR), 8.36 (d, J = 1.8 Hz, 1H, $\left.\mathrm{Ar}-\mathrm{H}_{7}\right), 7.89\left(\mathrm{dd}, J_{1}=8.5 \mathrm{~Hz}, J_{2}=1.8 \mathrm{~Hz}, 1 \mathrm{H}, \mathrm{Ar}-H_{5}\right), 7.71-7.63(\mathrm{~m}, 2 \mathrm{H}, 2 \times \mathrm{Ar}-\mathrm{H}), 7.50(\mathrm{~d}$, $\left.J=8.5 \mathrm{~Hz}, 1 \mathrm{H}, \mathrm{Ar}-\mathrm{H}_{4}\right), 6.95-6.89(\mathrm{~m}, 2 \mathrm{H}, 2 \times \mathrm{Ar}-\mathrm{H}), 3.74\left(\mathrm{~s}, 3 \mathrm{H}, \mathrm{Ar}-\mathrm{O}-\mathrm{CH}_{3}\right), 3.58-3.48(\mathrm{~m}$, $4 \mathrm{H}, 2 \times$ piperazine- $\left.\mathrm{CH}_{2}\right), 2.85-2.78 \mathrm{ppm}\left(\mathrm{m}, 4 \mathrm{H}, 2 \times\right.$ piperazine- $\left.\mathrm{CH}_{2}\right)$, not visible $(\mathrm{NH})$; ${ }^{13} \mathrm{C}\left(101 \mathrm{MHz},\left[\mathrm{D}_{6}\right] \mathrm{DMSO}, 25{ }^{\circ} \mathrm{C}, \mathrm{TMS}\right): \delta=170.5,165.1,155.9,155.6,132.9,130.6,128.0$, $125.9,122.3$ (2C), 121.4, 118.0, 114.2 (2C), 55.6, 49.9 (2C), 45.5 ppm (2C); HRMS (ESI+) $\mathrm{m} / \mathrm{z}$ calcd. for $\mathrm{C}_{19} \mathrm{H}_{20} \mathrm{~N}_{4} \mathrm{O}_{2} \mathrm{~S}+\mathrm{H}^{+}: 369.1380[\mathrm{M}+\mathrm{H}]^{+}$: found 369.1374; HPLC: $\mathrm{t}_{\mathrm{r}}=3.42 \mathrm{~min}(95.0 \%$ at $254 \mathrm{~nm})$.

4-(6-((Benzyl)carbamoyl)benzo[d]thiazol-2-yl)piperazine (5j): Yield: $96 \mathrm{mg}$ (81\%); light pink amorphous powder; $\mathrm{R}_{\mathrm{f}}(\mathrm{DCM}: \mathrm{MeOH}=9: 1)=0.13 ;{ }^{1} \mathrm{H} \mathrm{NMR}\left(400 \mathrm{MHz},\left[\mathrm{D}_{6}\right] \mathrm{DMSO}\right.$, $\left.25{ }^{\circ} \mathrm{C}, \mathrm{TMS}\right): \delta=8.95\left(\mathrm{t}, J=6.0 \mathrm{~Hz}, 1 \mathrm{H}, \mathrm{Ar}-\mathrm{CH}_{2}-\mathrm{NH}-\mathrm{COR}\right), 8.30\left(\mathrm{~d}, J=1.8 \mathrm{~Hz}, 1 \mathrm{H}, \mathrm{Ar}-\mathrm{H}_{7}\right)$, $7.83\left(\mathrm{dd}, J_{1}=8.5 \mathrm{~Hz}, J_{2}=1.8 \mathrm{~Hz}, 1 \mathrm{H}, \mathrm{Ar}-H_{5}\right), 7.45\left(\mathrm{~d}, J=8.5 \mathrm{~Hz}, 1 \mathrm{H}, \mathrm{Ar}-H_{4}\right), 7.35-7.29(\mathrm{~m}$, $4 \mathrm{H}, 4 \times \mathrm{Ar}-\mathrm{H}), 7.26-7.20(\mathrm{~m}, 1 \mathrm{H}, \mathrm{Ar}-\mathrm{H}), 4.48$ (d, $\left.\mathrm{J}=6.0 \mathrm{~Hz}, 2 \mathrm{H}, \mathrm{Ar}-\mathrm{CH}_{2}-\mathrm{NHCO}\right), 3.56-3.48$ $\left(\mathrm{m}, 4 \mathrm{H}, 2 \times\right.$ piperazine- $\left.\mathrm{CH}_{2}\right), 2.84-2.76 \mathrm{ppm}\left(\mathrm{m}, 4 \mathrm{H}, 2 \times\right.$ piperazine- $\left.\mathrm{CH}_{2}\right)$, not visible $(\mathrm{NH})$; ${ }^{13} \mathrm{C}\left(101 \mathrm{MHz},\left[\mathrm{D}_{6}\right] \mathrm{DMSO}, 25{ }^{\circ} \mathrm{C}\right.$, TMS): $\delta=170.3,166.3,155.3,140.3,130.6,128.7$ (2C), 127.7 (2C), 127.6, 127.2, 126.0, 121.1, 118.1, 49.3 (2C), 45.1 (2C), 43.1 ppm; HRMS (ESI+) $\mathrm{m} / \mathrm{z}$ calcd. for $\mathrm{C}_{19} \mathrm{H}_{20} \mathrm{~N}_{4} \mathrm{OS}+\mathrm{H}^{+}: 353.1430[\mathrm{M}+\mathrm{H}]^{+}$: found 353.1424; HPLC: $\mathrm{t}_{\mathrm{r}}=3.43 \mathrm{~min}(95.3 \%$ at $254 \mathrm{~nm})$.

4-(6-((3-Chlorobenzyl)carbamoyl)benzo[d]thiazol-2-yl)piperazine (5k): Yield: $48 \mathrm{mg}$ (74\%); white amorphous powder; $\mathrm{R}_{\mathrm{f}}(\mathrm{DCM}: \mathrm{MeOH}=9: 1)=0.06 ;{ }^{1} \mathrm{H}$ NMR $\left(400 \mathrm{MHz},\left[\mathrm{D}_{6}\right] \mathrm{DMSO}\right.$, $\left.25{ }^{\circ} \mathrm{C}, \mathrm{TMS}\right): \delta=8.99\left(\mathrm{t}, J=6.0 \mathrm{~Hz}, 1 \mathrm{H}, \mathrm{CH}_{2}-\mathrm{NH}-\mathrm{COR}\right), 8.30\left(\mathrm{~d}, J=1.9 \mathrm{~Hz}, 1 \mathrm{H}, \mathrm{Ar}-H_{7}\right)$, $7.82\left(\mathrm{dd}, J_{1}=8.5 \mathrm{~Hz}, J_{2}=1.9 \mathrm{~Hz}, 1 \mathrm{H}, \mathrm{Ar}-H_{5}\right), 7.46\left(\mathrm{~d}, J=8.5 \mathrm{~Hz}, 1 \mathrm{H}, \mathrm{Ar}-H_{4}\right), 7.39-7.33$ $(\mathrm{m}, 2 \mathrm{H}, 2 \times \mathrm{Ar}-\mathrm{H}), 7.33-7.27(\mathrm{~m}, 2 \mathrm{H}, 2 \times \mathrm{Ar}-\mathrm{H}), 4.47(\mathrm{~d}, J=6.0 \mathrm{~Hz}, 2 \mathrm{H}), 3.56-3.48(\mathrm{~m}, 4 \mathrm{H}$, $2 \times$ piperazine- $\left.\mathrm{CH}_{2}\right), 2.85-2.76 \mathrm{ppm}\left(\mathrm{m}, 4 \mathrm{H}, 2 \times\right.$ piperazine- $\left.\mathrm{CH}_{2}\right)$, not visible $(\mathrm{NH}) ;{ }^{13} \mathrm{C}$ (101 MHz, [D $\left.]_{\text {DMSO }} 25^{\circ} \mathrm{C}, \mathrm{TMS}\right): \delta=170.4,166.4,155.5,142.9,133.4,130.6,130.6,127.5$, 127.2, 127.1, 126.4, 126.0, 121.1, 118.1, 49.8 (2C), 45.5 (2C), 42.7 ppm; HRMS (ESI+) $\mathrm{m} / \mathrm{z}$ calcd. for $\mathrm{C}_{19} \mathrm{H}_{19} \mathrm{ClN}_{4} \mathrm{OS}+\mathrm{H}^{+}$: $387.1041[\mathrm{M}+\mathrm{H}]^{+}$: found 387.1032; HPLC: $\mathrm{t}_{\mathrm{r}}=4.26 \mathrm{~min}$ $(98.0 \%$ at $254 \mathrm{~nm})$.

4-(6-((4-Chlorobenzyl)carbamoyl)benzo[d]thiazol-2-yl)piperazine (5l): Yield: $59 \mathrm{mg}(92 \%)$; off-white amorphous powder; $\mathrm{R}_{\mathrm{f}}(\mathrm{DCM}: \mathrm{MeOH}=9: 1)=0.07 ;{ }^{1} \mathrm{H} \mathrm{NMR}\left(400 \mathrm{MHz},\left[\mathrm{D}_{6}\right] \mathrm{DMSO}\right.$, $\left.25{ }^{\circ} \mathrm{C}, \mathrm{TMS}\right): \delta=8.98\left(\mathrm{t}, J=6.0 \mathrm{~Hz}, 1 \mathrm{H}, \mathrm{t}, J=5.9 \mathrm{~Hz}, 1 \mathrm{H}, \mathrm{CH}_{2}-\mathrm{NH}-\mathrm{COR}\right), 8.29(\mathrm{~d}, J=1.8 \mathrm{~Hz}$, $\left.1 \mathrm{H}, \mathrm{Ar}-H_{7}\right), 7.82\left(\mathrm{dd}, J_{1}=8.5 \mathrm{~Hz}, J_{2}=1.8 \mathrm{~Hz}, 1 \mathrm{H}, \mathrm{Ar}-H_{5}\right), 7.46\left(\mathrm{~d}, J=8.5 \mathrm{~Hz}, 1 \mathrm{H}, \mathrm{Ar}-H_{4}\right)$, 7.41-7.30 (m, 4H, $4 \times \mathrm{Ar}-\mathrm{H}), 4.46\left(\mathrm{~d}, J=6.0 \mathrm{~Hz}, 2 \mathrm{H}, \mathrm{RCO}-\mathrm{NH}-\mathrm{CH}_{2}-\mathrm{Ph}\right), 3.57-3.46(\mathrm{~m}, 4 \mathrm{H}$, $2 \times$ piperazine- $\left.\mathrm{CH}_{2}\right), 2.86-2.77\left(\mathrm{~m}, 4 \mathrm{H}, 2 \times\right.$ piperazine- $\left.\mathrm{CH}_{2}\right), 2.77-2.69 \mathrm{ppm}(\mathrm{m}, 1 \mathrm{H}, \mathrm{NH})$; ${ }^{13} \mathrm{C}\left(101 \mathrm{MHz},\left[\mathrm{D}_{6}\right] \mathrm{DMSO}, 25^{\circ} \mathrm{C}, \mathrm{TMS}\right): \delta=170.4,166.3,155.4,139.4,131.7,130.6,129.6$ (2C), 128.7 (2C), 127.3, 126.0, 121.1, 118.0, 49.7 (2C), 45.4 (2C), 42.5 ppm; HRMS (ESI+) $\mathrm{m} / \mathrm{z}$ calcd. for $\mathrm{C}_{19} \mathrm{H}_{19} \mathrm{ClN}_{4} \mathrm{OS}+\mathrm{H}^{+}$: $387.1041[M+\mathrm{H}]^{+}$: found 387.1034; HPLC: $\mathrm{t}_{\mathrm{r}}=4.15 \mathrm{~min}$ (97.7\% at $254 \mathrm{~nm})$.

4-(6-((Indane-1-yl)carbamoyl)benzo[d]thiazol-2-yl)piperazine (5m): Yield: $52 \mathrm{mg}(83 \%)$; white amorphous powder; $\mathrm{R}_{\mathrm{f}}(\mathrm{DCM}: \mathrm{MeOH}=9: 1)=0.07 ;{ }^{1} \mathrm{H}$ NMR $\left(400 \mathrm{MHz},\left[\mathrm{D}_{6}\right] \mathrm{DMSO}\right.$, $\left.25^{\circ} \mathrm{C}, \mathrm{TMS}\right): \delta=8.66(\mathrm{~d}, J=8.3 \mathrm{~Hz}, 1 \mathrm{H}, \mathrm{CH}-\mathrm{NH}-\mathrm{CO}), 8.32\left(\mathrm{~d}, J=1.7 \mathrm{~Hz}, 1 \mathrm{H}, \mathrm{Ar}-H_{7}\right), 7.86$ $\left(\mathrm{dd}, J_{1}=8.5 \mathrm{~Hz}, J_{2}=1.7 \mathrm{~Hz}, 1 \mathrm{H}, \mathrm{Ar}-H_{5}\right), 7.44\left(\mathrm{~d}, J=8.5 \mathrm{~Hz}, 1 \mathrm{H}, \mathrm{Ar}-\mathrm{H}_{4}\right), 7.29-7.14(\mathrm{~m}, 4 \mathrm{H}$, $4 \times \operatorname{Ar}-H), 5.56(\mathrm{q}, J=8.3 \mathrm{~Hz}, 1 \mathrm{H}$, indane- $H), 3.55-3.48\left(\mathrm{~m}, 4 \mathrm{H}, 2 \times\right.$ piperazine- $\left.\mathrm{CH}_{2}\right), 3.00$ 
$\left(\mathrm{ddd}, J_{1}=15.6 \mathrm{~Hz}, J_{2}=8.8 \mathrm{~Hz}, J_{3}=2.9 \mathrm{~Hz}, 1 \mathrm{H}\right.$, indane- $\left.H\right), 2.90-2.77(\mathrm{~m}, 5 \mathrm{H}, 2 \times$ piperazine$\mathrm{CH}_{2}$, and indane- $\left.H\right), 2.47-2.40(\mathrm{~m}, 1 \mathrm{H}), 2.05-1.92 \mathrm{ppm}(\mathrm{m}, 1 \mathrm{H}$, indane- $H)$, not visible $(\mathrm{NH})$; ${ }^{13} \mathrm{C}\left(101 \mathrm{MHz},\left[\mathrm{D}_{6}\right.\right.$ ] DMSO, $25^{\circ} \mathrm{C}$, TMS): $\delta=170.3,166.2,155.3,144.8,143.4,130.4,127.8$, $127.5,126.8,126.2,124.9,124.5,121.2,118.0,54.7,49.8$ (2C), 45.5 (2C), 33.2, 30.3 ppm; HRMS (ESI+) $m / z$ calcd. for $\mathrm{C}_{21} \mathrm{H}_{22} \mathrm{~N}_{4} \mathrm{OS}+\mathrm{H}^{+}: 379.1587[\mathrm{M}+\mathrm{H}]^{+}$: found 379.1579; HPLC: $\mathrm{t}_{\mathrm{r}}=4.22$ $\min (96.6 \%$ at $254 \mathrm{~nm})$.

2-Amino- $N$-(4-chlorophenyl)benzo[ $d]$ thiazole-6-carboxamide (6): The reaction was performed under an argon atmosphere. 2-Aminobenzo[d]thiazole-6-carboxylic acid (2.13 g, $11.0 \mathrm{mmol})$ was dissolved in DMF $(40 \mathrm{~mL})$. EDC (2.04 g, $13.2 \mathrm{mmol})$, HOBt $(1.93 \mathrm{~g}$, $14.3 \mathrm{mmol})$ and $\mathrm{N}$-methylmorpholine $(2.86 \mathrm{~mL}, 27.4 \mathrm{mmol})$ were added in an ice bath. After $20 \mathrm{~min}$, 4-chloroaniline $(1.82 \mathrm{~g}, 14.3 \mathrm{mmol})$ was added to the reaction mixture, which was then left to stir for 2 days at room temperature. The solvent was removed under reduced pressure, and the residue was taken up in ethyl acetate $(200 \mathrm{~mL})$ and washed with $1 \mathrm{M}$ $\mathrm{NaOH}(3 \times 75 \mathrm{~mL}), 1 \%(w / v)$ citric acid $(3 \times 75 \mathrm{~mL})$ and with saturated $\mathrm{NaCl}(100 \mathrm{~mL})$. The organic phase was dried over $\mathrm{Na}_{2} \mathrm{SO}_{4}$, filtered, and the solvent was evaporated under reduced pressure. The product was purified with precipitation from a mixture of ethyl acetate and hexane. Yield: $1.82 \mathrm{~g}(55 \%)$; off-white amorphous powder; $\mathrm{R}_{\mathrm{f}}(\mathrm{DCM}: \mathrm{MeOH}=9: 1)$ $=0.14 ;{ }^{1} \mathrm{H}$ NMR $\left(400 \mathrm{MHz},\left[\mathrm{D}_{6}\right] \mathrm{DMSO}, 25{ }^{\circ} \mathrm{C}, \mathrm{TMS}\right): \delta=10.25(\mathrm{~s}, 1 \mathrm{H}, \mathrm{Ar}-\mathrm{N} H-\mathrm{COR}) 8.29(\mathrm{~d}$, $J=1.7 \mathrm{~Hz}, 1 \mathrm{H}, \mathrm{Ar}-\mathrm{NH}-\mathrm{COR}), 7.87-7.80(\mathrm{~m}, 5 \mathrm{H}, 5 \times \mathrm{Ar}-\mathrm{H}), 7.45-7.37 \mathrm{ppm}(\mathrm{m}, 3 \mathrm{H}, \mathrm{Ar}-\mathrm{H}$ and $\left.\mathrm{NH}_{2}\right) ;{ }^{13} \mathrm{C}\left(101 \mathrm{MHz},\left[\mathrm{D}_{6}\right] \mathrm{DMSO}, 25^{\circ} \mathrm{C}, \mathrm{TMS}\right): \delta=169.3,165.7,156.2,138.9,131.4,129.0(2 \mathrm{C})$, $127.4 ; 127.4,126.2,122.1(2 \mathrm{C}), 121.3,117.4$ ppm; LC-MS (ESI+): $m / z 345.1\left[\mathrm{M}+\mathrm{H}+\mathrm{CH}_{3} \mathrm{CN}\right]^{+}$ (calcd. $m / z=303.0$ for $\mathrm{C}_{14} \mathrm{H}_{10} \mathrm{ClN}_{3} \mathrm{OS}$ ).

2-Bromo- $\mathrm{N}$-(4-chlorophenyl)benzo[d]thiazole-6-carboxamide (7): Compound 6 (1.80 g, $5.93 \mathrm{mmol})$ and $\mathrm{CuBr}_{2}(2.65 \mathrm{~g}, 11.9 \mathrm{mmol})$ were dissolved in acetonitrile $(90 \mathrm{~mL})$. tert-Butyl nitrite $(1.41 \mathrm{~mL}, 11.9 \mathrm{mmol}, 867 \mathrm{mg} / \mathrm{mL})$ was added in an ice bath, and the reaction mixture was stirred overnight at room temperature. The solvent was then removed under reduced pressure, and the residue was taken up in ethyl acetate $(150 \mathrm{~mL})$ and saturated $\mathrm{NH}_{4} \mathrm{Cl}$ $(50 \mathrm{~mL})$. The precipitate that formed was filtered off under pressure. The organic phase was additionally washed with saturated $\mathrm{NH}_{4} \mathrm{Cl}(3 \times 75 \mathrm{~mL})$ and saturated $\mathrm{NaCl}$. The organic phase was dried over $\mathrm{Na}_{2} \mathrm{SO}_{4}$, filtered, and the solvent was evaporated under reduced pressure. Yield: $1.80 \mathrm{~g}(83 \%)$; orange amorphous powder; $\mathrm{R}_{\mathrm{f}}(\mathrm{EtOAc:Hex}=1: 2)=0.34 ;{ }^{1} \mathrm{H}$ NMR $\left(400 \mathrm{MHz},\left[\mathrm{D}_{6}\right] \mathrm{DMSO}, 25^{\circ} \mathrm{C}\right.$, TMS): $\delta=10.58(\mathrm{~s}, 1 \mathrm{H}, \mathrm{Ar}-\mathrm{NH}-\mathrm{COR}), 8.73-8.70(\mathrm{~m}, 1 \mathrm{H}$, Ar-H), 8.16-8.12 (m, 1H, Ar- $H), 8.09$ (m, 1H, Ar- H), 7.87-7.80 (m, 2H, $2 \times$ Ar- H), 7.48-7.40 ppm (m, 2H, $2 \times \mathrm{Ar}-H) ;{ }^{13} \mathrm{C}\left(101 \mathrm{MHz},\left[\mathrm{D}_{6}\right] \mathrm{DMSO}, 25^{\circ} \mathrm{C}, \mathrm{TMS}\right): \delta=165.4,154.2,143.2$, 138.5, 137.4, 132.6, 129.1 (2C), 127.9, 126.8, 122.7, 122.5, 122.3 ppm (2C); LC-MS (ESI-): $\mathrm{m} / \mathrm{z}$ $365.0[\mathrm{M}-\mathrm{H}]^{-}$(calcd. $m / z=365.9$ for $\mathrm{C}_{14} \mathrm{H}_{8} \mathrm{BrClN}_{2} \mathrm{OS}$ ).

\section{General procedure for the synthesis of compounds 8a-n}

The reaction was performed under an argon atmosphere. Compound 7 (1 equiv) was dissolved in THF, and triethylamine was added ( 2.5 equiv). The corresponding amine (1.25 equiv) was added to the reaction mixture, and the solution was stirred overnight at room temperature. The precipitate formed was filtered off. The solvent was then evaporated under reduced pressure, and the residue was dissolved in ethyl acetate (50-75 mL) and $1 \%(w / v)$ citric acid $(30 \mathrm{~mL})$. The organic phase was additionally washed with $1 \%$ $(w / v)$ citric acid $(2 \times 30 \mathrm{~mL})$ and saturated $\mathrm{NaCl}(30 \mathrm{~mL})$. The organic phase was then dried over $\mathrm{Na}_{2} \mathrm{SO}_{4}$, filtered, and the solvent was evaporated under reduced pressure. The products were purified using column chromatography.

3-N-Boc-1- $N$-(6-((4-Chlorophenyl)carbamoyl)benzo[d]thiazol-2-yl)1,3-diaminopropane (8a): The product was purified using column chromatography (mobile phase: $\mathrm{DCM}: \mathrm{MeOH}=25: 1$ ). Yield: $159 \mathrm{mg}(42 \%)$; white amorphous powder; $\mathrm{R}_{\mathrm{f}}(\mathrm{DCM}: \mathrm{MeOH}=20: 1)=0.19 ;{ }^{1} \mathrm{H}$ NMR (400 MHz, [D ${ }_{6}$ ]DMSO, $\left.25^{\circ} \mathrm{C}, \mathrm{TMS}\right): \delta=10.26(\mathrm{~s}, 1 \mathrm{H}, \mathrm{Ar}-\mathrm{NH}-\mathrm{COR}), 8.34(\mathrm{t}, J=5.3 \mathrm{~Hz}, 1 \mathrm{H}$, Ar- $\left.\mathrm{NH}-\mathrm{CH}_{2}\right), 8.29(\mathrm{~d}, J=1.7 \mathrm{~Hz}, 1 \mathrm{H}, \mathrm{Ar}-\mathrm{H}), 7.89-7.79(\mathrm{~m}, 3 \mathrm{H}, 3 \times \mathrm{Ar}-\mathrm{H}), 7.46(\mathrm{~d}, J=8.4 \mathrm{~Hz}$, $1 \mathrm{H}, \mathrm{Ar}-H), 7.43-7.38(\mathrm{~m}, 2 \mathrm{H}, 2 \times \mathrm{Ar}-H), 6.91\left(\mathrm{t}, J=5.3 \mathrm{~Hz}, 1 \mathrm{H}, \mathrm{CO}-\mathrm{NH}-\mathrm{CH}_{2}\right), 3.40(\mathrm{dd}$, $\left.J_{1}=12.6 \mathrm{~Hz}, J_{2}=6.7 \mathrm{~Hz}, 2 \mathrm{H}, \mathrm{CH}_{2}\right), 3.02\left(\mathrm{dd}, J_{1}=12.6 \mathrm{~Hz}, J_{2}=6.7 \mathrm{~Hz}, 2 \mathrm{H}, \mathrm{CH}_{2}\right), 1.72(\mathrm{p}$, 
$\left.J=6.7 \mathrm{~Hz}, 2 \mathrm{H}, \mathrm{CH}_{2}\right), 1.38 \mathrm{ppm}\left(\mathrm{s}, 9 \mathrm{H}, \mathrm{COC}\left(\mathrm{CH}_{3}\right)_{3}\right) ; \mathrm{LC}-\mathrm{MS}(\mathrm{ESI}+): \mathrm{m} / z 461.2[\mathrm{M}+\mathrm{H}]^{+}$ (calcd. $m / z=460.1$ for $\mathrm{C}_{22} \mathrm{H}_{25} \mathrm{~N}_{4} \mathrm{O}_{3} \mathrm{~S}$ ).

3-(N-Boc-Amino)-1-(6-((4-chlorophenyl)carbamoyl)benzo[d]thiazol-2-yl)piperidine (8b): The product was purified using column chromatography (mobile phase: DCM:MeOH = 40:1). Yield: $108 \mathrm{mg}(33 \%)$; light orange amorphous powder; $\mathrm{R}_{\mathrm{f}}(\mathrm{DCM}: \mathrm{MeOH}=30: 1)=$ $0.08 ;{ }^{1} \mathrm{H}$ NMR $\left(400 \mathrm{MHz},\left[\mathrm{D}_{6}\right.\right.$ ]DMSO, $\left.25{ }^{\circ} \mathrm{C}, \mathrm{TMS}\right): \delta=10.28$ (s, $\left.1 \mathrm{H}, \mathrm{Ar}-\mathrm{NH}-\mathrm{COR}\right), 8.36(\mathrm{~d}$, $\left.J=1.8 \mathrm{~Hz}, 1 \mathrm{H}, \mathrm{Ar}-H_{7}\right), 7.89\left(\mathrm{dd}, J_{1}=8.5 \mathrm{~Hz}, J_{2}=1.8 \mathrm{~Hz}, 1 \mathrm{H}, \mathrm{Ar}-H_{5}\right), 7.86-7.78(\mathrm{~m}, 2 \mathrm{H}, 2 \times$ Ar- $H), 7.51\left(\mathrm{~d}, J=8.5 \mathrm{~Hz}, 1 \mathrm{H}, \mathrm{Ar}-H_{4}\right), 7.43-7.37(\mathrm{~m}, 2 \mathrm{H}, 2 \times \mathrm{Ar}-H), 7.08(\mathrm{~d}, J=7.1 \mathrm{~Hz}, 1 \mathrm{H}$, CH-NH-Boc), $4.05-3.97(\mathrm{~m}, 1 \mathrm{H}$, piperidine- $H), 3.84-3.74(\mathrm{~m}, 1 \mathrm{H}$, piperidine- $H), 3.53-3.42$ $(\mathrm{m}, 1 \mathrm{H}$, piperidine $-H), 3.11\left(\mathrm{dd}, J_{1}=12.6 \mathrm{~Hz}, J_{2}=9.1 \mathrm{~Hz}, 1 \mathrm{H}\right.$, piperidine $\left.-H\right), 1.92-1.78(\mathrm{~m}$, $2 \mathrm{H}, 2 \times$ piperidine- $H), 1.63-1.32 \mathrm{ppm}\left(\mathrm{m}, 11 \mathrm{H}, 2 \times\right.$ piperidine- $H$ and $\left.\mathrm{COC}\left(\mathrm{CH}_{3}\right)_{3}\right) ; \mathrm{LC}-\mathrm{MS}$ (ESI+): $m / z 487.4[\mathrm{M}+\mathrm{H}]^{+}$(calcd. $m / z=486.1$ for $\mathrm{C}_{24} \mathrm{H}_{27} \mathrm{ClN}_{4} \mathrm{O}_{3} \mathrm{~S}$ ).

3-(S)-(N-Boc-Amino)-1-(6-((4-chlorophenyl)carbamoyl)benzo[d]thiazol-2-yl)pyrrolidine (8c): The product was purified using column chromatography (mobile phase: DCM:MeOH = 40:1). Yield: $179 \mathrm{mg}(56 \%)$; white amorphous powder; $\mathrm{R}_{\mathrm{f}}(\mathrm{DCM}: \mathrm{MeOH}=9: 1)=0.32 ;{ }^{1} \mathrm{H}$ NMR $\left(400 \mathrm{MHz},\left[\mathrm{D}_{6}\right] \mathrm{DMSO}, 25^{\circ} \mathrm{C}, \mathrm{TMS}\right): \delta=10.28(\mathrm{~s}, 1 \mathrm{H}, \mathrm{Ar}-\mathrm{NH}-\mathrm{COR}), 8.38(\mathrm{~d}, J=1.9 \mathrm{~Hz}$, $\left.1 \mathrm{H}, \mathrm{Ar}-H_{7}\right), 7.89\left(\mathrm{dd}, J_{1}=8.5 \mathrm{~Hz}, J_{2}=1.9 \mathrm{~Hz}, 1 \mathrm{H}, \mathrm{Ar}-H_{5}\right), 7.85-7.79(\mathrm{~m}, 2 \mathrm{H}, 2 \times \mathrm{Ar}-\mathrm{H})$, $7.54\left(\mathrm{~d}, J=8.5 \mathrm{~Hz}, 1 \mathrm{H}, \mathrm{Ar}-H_{4}\right), 7.44-7.38(\mathrm{~m}, 2 \mathrm{H}, 2 \times \mathrm{Ar}-H), 7.37-7.33(\mathrm{~m}, 1 \mathrm{H}, \mathrm{CH}-\mathrm{NH}-$ Boc), $4.24-4.14(\mathrm{~m}, 1 \mathrm{H}$, pyrrolidine- $H), 3.79-3.51(\mathrm{~m}, 3 \mathrm{H}, 3 \times$ pyrrolidine- $H), 3.43-3.36(\mathrm{~m}$, $1 \mathrm{H}$, pyrrolidine- $H), 2.28-2.17(\mathrm{~m}, 1 \mathrm{H}$, pyrrolidine- $H), 2.02-1.91(\mathrm{~m}, 1 \mathrm{H}$, pyrrolidine- $H)$, $1.40 \mathrm{ppm}\left(\mathrm{s}, 9 \mathrm{H}, \mathrm{COC}\left(\mathrm{CH}_{3}\right)_{3}\right) ;[\alpha]_{\mathrm{D}}{ }^{25}=9.5(\mathrm{c}=0.86$ in DMF); LC-MS (ESI $): \mathrm{m} / z 473.3$ $[\mathrm{M}+\mathrm{H}]^{+}$(calcd. $m / z=472.1$ for $\mathrm{C}_{23} \mathrm{H}_{25} \mathrm{ClN}_{4} \mathrm{O}_{3} \mathrm{~S}$ ).

3-(R)-(N-Boc-Amino)-1-(6-((4-chlorophenyl)carbamoyl)benzo[d]thiazol-2-yl)pyrrolidine (8d): The product was purified using column chromatography (mobile phase: DCM:MeOH = 30:1). Yield: $130 \mathrm{mg}(67 \%)$; white amorphous powder; $\mathrm{R}_{\mathrm{f}}(\mathrm{DCM}: \mathrm{MeOH}=9: 1)=0.50 ;{ }^{1} \mathrm{H}$ NMR (400 MHz, [D D DMSO $\left._{2}{ }^{\circ} \mathrm{C}, \mathrm{TMS}\right): \delta=10.28$ (s, $\left.1 \mathrm{H}, \mathrm{Ar}-\mathrm{NH}-\mathrm{COR}\right), 8.38(\mathrm{~d}, J=1.9 \mathrm{~Hz}$, $\left.1 \mathrm{H}, \mathrm{Ar}-H_{7}\right), 7.89\left(\mathrm{dd}, J_{1}=8.5 \mathrm{~Hz}, J_{2}=1.9 \mathrm{~Hz}, 1 \mathrm{H}, \mathrm{Ar}-H_{5}\right), 7.85-7.79(\mathrm{~m}, 2 \mathrm{H}, 2 \times \mathrm{Ar}-\mathrm{H})$, $7.54\left(\mathrm{~d}, J=8.5 \mathrm{~Hz}, 1 \mathrm{H}, \mathrm{Ar}-\mathrm{H}_{4}\right), 7.45-7.38(\mathrm{~m}, 2 \mathrm{H}, 2 \times \mathrm{Ar}-\mathrm{H}), 7.35(\mathrm{~d}, J=6.3 \mathrm{~Hz}, 1 \mathrm{H}, \mathrm{CH}-$ NH-Boc), 4.22-4.15 (m, $1 \mathrm{H}$, pyrrolidine- $H)$, 3.78-3.51 (m, 3H, $3 \times$ pyrrolidine- $H), 3.45-3.36$ $(\mathrm{m}, 1 \mathrm{H}$, pyrrolidine $-H), 2.28-2.17(\mathrm{~m}, 1 \mathrm{H}$, pyrrolidine $-H), 2.01-1.92(\mathrm{~m}, 1 \mathrm{H}$, pyrrolidine $-H)$, $1.40 \mathrm{ppm}\left(\mathrm{s}, 9 \mathrm{H}, \mathrm{COC}\left(\mathrm{CH}_{3}\right)_{3}\right) ;[\alpha]_{\mathrm{D}}{ }^{25}=-9.5$ (c = 0,69 in DMF); LC-MS (ESI+): $\mathrm{m} / z 473.0$ $[\mathrm{M}+\mathrm{H}]^{+}$(calcd. $m / z=472.1$ for $\mathrm{C}_{23} \mathrm{H}_{25} \mathrm{ClN}_{4} \mathrm{O}_{3} \mathrm{~S}$ ).

4-(N-Boc-Aminomethyl)-1-(6-((4-chlorophenyl)carbamoyl)benzo[d]thiazol-2-yl)piperidine (8e): The product was purified using column chromatography (mobile phase: EtOAc:Hex = 1:1). Yield: $67 \mathrm{mg}(20 \%)$; white amorphous powder; $\mathrm{R}_{\mathrm{f}}(\mathrm{EtOAc}: \mathrm{Hex}=2: 1)=0.34 ;{ }^{1} \mathrm{H}$ NMR (400 MHz, [D $\mathrm{D}_{6}$ DMSO, $\left.25^{\circ} \mathrm{C}, \mathrm{TMS}\right): \delta=10.28(\mathrm{~s}, 1 \mathrm{H}, \mathrm{Ar}-\mathrm{NH}-\mathrm{COR}), 8.37(\mathrm{~d}, J=1.9 \mathrm{~Hz}, 1 \mathrm{H}$, Ar- $\left.H_{7}\right), 7.89\left(\mathrm{dd}, J_{1}=8.5 \mathrm{~Hz}, J_{2}=1.9 \mathrm{~Hz}, 1 \mathrm{H}, \mathrm{Ar}-H_{5}\right), 7.84-7.79(\mathrm{~m}, 2 \mathrm{H}, 2 \times \mathrm{Ar}-H), 7.50(\mathrm{~d}$, $\left.J=8.5 \mathrm{~Hz}, 1 \mathrm{H}, \mathrm{Ar}-\mathrm{H}_{4}\right), 7.43-7.37(\mathrm{~m}, 2 \mathrm{H}, 2 \times \mathrm{Ar}-\mathrm{H}), 6.96\left(\mathrm{t}, J=5.8 \mathrm{~Hz}, 1 \mathrm{H}, \mathrm{CH}_{2}-\mathrm{NH}-\mathrm{Boc}\right)$, 4.15-4.00 (m, 2H, $2 \times$ methylpiperdine- $H), 3.24-3.13(\mathrm{~m}, 2 \mathrm{H}, 2 \times$ methylpiperdine- $H), 2.86$ $(\mathrm{t}, J=6.2 \mathrm{~Hz}, 2 \mathrm{H}, 2 \times$ methylpiperdine- $H), 1.80-1.64(\mathrm{~m}, 3 \mathrm{H}, 3 \times$ methylpiperdine- $H), 1.38$ (s, 9H, COC $\left.\left(\mathrm{CH}_{3}\right)_{3}\right), 1.27-1.11 \mathrm{ppm}(\mathrm{m}, 2 \mathrm{H}, 2 \times$ methylpiperdine- $H$ ); LC-MS (ESI): $\mathrm{m} / \mathrm{z}$ $501.4[\mathrm{M}+\mathrm{H}]^{+}$(calcd. $m / z=500.2$ for $\mathrm{C}_{25} \mathrm{H}_{29} \mathrm{ClN}_{4} \mathrm{O}_{3} \mathrm{~S}$ ).

1-Boc-4-((6-((4-Chlorophenyl)carbamoyl)benzo[d]thiazol-2-yl)amino)piperidine (8f): The product was purified using column chromatography (mobile phase: DCM:MeOH = 20:1). Yield: $49 \mathrm{mg}(15 \%)$; white amorphous powder; $\mathrm{R}_{\mathrm{f}}(\mathrm{DCM}: \mathrm{MeOH}=20: 1)=0.21$; ${ }^{1} \mathrm{H}$ NMR (400 MHz, [D $\mathrm{D}_{6}$ DMSO, $25{ }^{\circ} \mathrm{C}$, TMS): $\delta=10.26$ (s, $\left.1 \mathrm{H}, \mathrm{Ar}-\mathrm{NH}-\mathrm{COR}\right), 8.38(\mathrm{~d}$, $J=7.4 \mathrm{~Hz}, 1 \mathrm{H}, \mathrm{Ar}-\mathrm{NH}-\mathrm{CH}), 8.29(\mathrm{~d}, J=1.8 \mathrm{~Hz}, 1 \mathrm{H}, \mathrm{Ar}-\mathrm{H}), 7.88-7.78(\mathrm{~m}, 3 \mathrm{H}, 3 \times \mathrm{Ar}-\mathrm{H}), 7.47$ $(\mathrm{d}, J=8.5 \mathrm{~Hz}, 1 \mathrm{H}, \mathrm{Ar}-H), 7.44-7.36(\mathrm{~m}, 2 \mathrm{H}, 2 \times \mathrm{Ar}-\mathrm{H}), 4.02-3.81(\mathrm{~m}, 3 \mathrm{H}, 3 \times$ piperidine $-H)$, 3.05-2.88 (m, 2H, $2 \times$ piperidine- $H), 2.01-1.93(\mathrm{~m}, 2 \mathrm{H}, 2 \times$ piperidine- $H), 1.45-1.30 \mathrm{ppm}$ $\left(\mathrm{m}, 11 \mathrm{H}, \mathrm{COC}\left(\mathrm{CH}_{3}\right)_{3}+2 \times\right.$ piperidine- $\left.H\right) ; \mathrm{LC}-\mathrm{MS}(\mathrm{ESI}+): \mathrm{m} / \mathrm{z} 487.1[\mathrm{M}+\mathrm{H}]^{+}($calcd. $\mathrm{m} / \mathrm{z}=$ 486.1 for $\left.\mathrm{C}_{24} \mathrm{H}_{27} \mathrm{ClN}_{4} \mathrm{O}_{3} \mathrm{~S}\right)$. 
2-Boc-7-(6-((4-Chlorophenyl)carbamoyl)benzo[d]thiazol-2-yl)-2,7-diazaspiro[4.4]nonane (8g): The product was purified using column chromatography (mobile phase: DCM:MeOH = 20:1). Yield: $141 \mathrm{mg}(51 \%)$; off-white amorphous powder; $\mathrm{R}_{\mathrm{f}}(\mathrm{DCM}: \mathrm{MeOH}=9: 1)=$ $0.44 ;{ }^{1} \mathrm{H}$ NMR $\left(400 \mathrm{MHz},\left[\mathrm{D}_{6}\right.\right.$ ]DMSO, $\left.25^{\circ} \mathrm{C}, \mathrm{TMS}\right): \delta=10.28$ (s, 1H, Ar-NH-COR), $8.39(\mathrm{~d}$, $\left.J=1.9 \mathrm{~Hz}, 1 \mathrm{H}, \mathrm{Ar}-H_{7}\right), 7.90\left(\mathrm{dd}, J_{1}=8.5 \mathrm{~Hz}, J_{2}=1.9 \mathrm{~Hz}, 1 \mathrm{H}, \mathrm{Ar}-H_{5}\right), 7.86-7.79(\mathrm{~m}, 2 \mathrm{H}, 2 \times$ Ar- $H), 7.53\left(\mathrm{~d}, J=8.5 \mathrm{~Hz}, 1 \mathrm{H}, \mathrm{Ar}-H_{4}\right), 7.44-7.36(\mathrm{~m}, 2 \mathrm{H}, 2 \times \mathrm{Ar}-H), 3.65\left(\mathrm{~s}, 2 \mathrm{H}, \mathrm{CH}_{2}\right), 3.52(\mathrm{~s}$, $\left.2 \mathrm{H}, \mathrm{CH}_{2}\right), 2.08-2.01\left(\mathrm{~m}, 2 \mathrm{H}, \mathrm{CH}_{2}\right), 1.97-1.84\left(\mathrm{~m}, 2 \mathrm{H}, \mathrm{CH}_{2}\right), 1,40 \mathrm{ppm}\left(\mathrm{s}, 9 \mathrm{H}, \mathrm{COC}\left(\mathrm{CH}_{3}\right)_{3}\right)$. covered with solvent $\left(2 \times \mathrm{CH}_{2}\right)$; LC-MS (ESI+): $m / z 513.2[\mathrm{M}+\mathrm{H}]^{+}$(calcd. $m / z=512.2$ for $\mathrm{C}_{26} \mathrm{H}_{29} \mathrm{ClN}_{4} \mathrm{O}_{3} \mathrm{~S}$ ).

2-Boc-5-(6-((4-Chlorophenyl)carbamoyl)benzo[d]thiazol-2-yl)hexahydropyrrolo[3,4-c] pyrrole (8h): The product was purified using column chromatography (mobile phase: DCM:MeOH = 20:1). Yield: $66 \mathrm{mg}(24 \%)$; white amorphous powder; $\mathrm{R}_{\mathrm{f}}(\mathrm{DCM}: \mathrm{MeOH}=$ 20:1) $=0.14 ;{ }^{1} \mathrm{H} \mathrm{NMR}\left(400 \mathrm{MHz},\left[\mathrm{D}_{6}\right] \mathrm{DMSO}, 25^{\circ} \mathrm{C}, \mathrm{TMS}\right): \delta=10.28$ (s, $\left.1 \mathrm{H}, \mathrm{Ar}-\mathrm{NH}-\mathrm{COR}\right)$, $8.39\left(\mathrm{~d}, J=1.9 \mathrm{~Hz}, 1 \mathrm{H}, \mathrm{Ar}-H_{7}\right), 7.90\left(\mathrm{dd}, J_{1}=8.5 \mathrm{~Hz}, J_{2}=1.9 \mathrm{~Hz}, 1 \mathrm{H}, \mathrm{Ar}-H_{5}\right), 7.85-7.78(\mathrm{~m}$, $2 \mathrm{H}, 2 \times \mathrm{Ar}-\mathrm{H}), 7.54\left(\mathrm{~d}, J=8.5 \mathrm{~Hz}, 1 \mathrm{H}, \mathrm{Ar}-\mathrm{H}_{4}\right), 7.43-7.37(\mathrm{~m}, 2 \mathrm{H}, 2 \times \mathrm{Ar}-\mathrm{H}), 3.83-3.73(\mathrm{~m}$, $2 \mathrm{H}, 2 \times \mathrm{CH}), 3.61-3.50(\mathrm{~m}, 2 \mathrm{H}, 2 \times \mathrm{CH}), 3.49-3.39(\mathrm{~m}, 2 \mathrm{H}, 2 \times \mathrm{CH}), 3.26-3.18(\mathrm{~m}, 2 \mathrm{H}, 2 \times$ $\mathrm{CH}), 3.12-3.01(\mathrm{~m}, 2 \mathrm{H}, 2 \times \mathrm{CH}), 1.39 \mathrm{ppm}\left(\mathrm{s}, 9 \mathrm{H}, \mathrm{COC}\left(\mathrm{CH}_{3}\right)_{3}\right)$; LC-MS (ESI+): $\mathrm{m} / z 499.0$ $[\mathrm{M}+\mathrm{H}]^{+}$(calcd. $m / z=498.1$ for $\mathrm{C}_{25} \mathrm{H}_{27} \mathrm{ClN}_{4} \mathrm{O}_{3} \mathrm{~S}$ ).

4-(N-Boc-Amino)-1-(6-((4-chlorophenyl)carbamoyl)benzo[d]thiazol-2-yl)piperidine (8i): The product was purified using column chromatography (mobile phase: DCM:MeOH = 30:1). Yield: $75 \mathrm{mg}(28 \%)$; white amorphous powder; $\mathrm{R}_{\mathrm{f}}(\mathrm{DCM}: \mathrm{MeOH}=30: 1)=0.28 ;{ }^{1} \mathrm{H}$ NMR (400 MHz, [D ${ }_{6}$ DMSO, $\left.25^{\circ} \mathrm{C}, \mathrm{TMS}\right): \delta=10.28$ (s, 1H, Ar-NH-COR), 8.37 (d, J = 1.9 Hz, $\left.1 \mathrm{H}, \mathrm{Ar}-H_{7}\right), 7.89\left(\mathrm{dd}, J_{1}=8.5 \mathrm{~Hz}, J_{2}=1.9 \mathrm{~Hz}, 1 \mathrm{H}, \mathrm{Ar}-H_{5}\right), 7.86-7.78(\mathrm{~m}, 2 \mathrm{H}, 2 \times \mathrm{Ar}-H), 7.51$ $\left(\mathrm{d}, J=8.5 \mathrm{~Hz}, 1 \mathrm{H}, \mathrm{Ar}-\mathrm{H}_{4}\right), 7.43-7.37(\mathrm{~m}, 2 \mathrm{H}, 2 \times \mathrm{Ar}-\mathrm{H}), 6.95(\mathrm{~d}, J=7.9 \mathrm{~Hz}, 1 \mathrm{H}, \mathrm{CH}-\mathrm{NH}-\mathrm{Boc})$, $4.02(\mathrm{~d}, J=13.5 \mathrm{~Hz}, 2 \mathrm{H}, 2 \times$ piperidine $-H), 3.64-3.52(\mathrm{~m}, 1 \mathrm{H}$, piperidine $-H), 3.31-3.26$ $(\mathrm{m}, 2 \mathrm{H}, 2 \times$ piperidine- $H), 1.93-1.79(\mathrm{~m}, 2 \mathrm{H}, 2 \times$ piperidine- $H), 1.50-1.41(\mathrm{~m}, 2 \mathrm{H}, 2 \times$ piperidine-H), $1.39 \mathrm{ppm}\left(\mathrm{s}, 9 \mathrm{H}, \mathrm{COC}\left(\mathrm{CH}_{3}\right)_{3}\right) ;{ }^{13} \mathrm{C}\left(101 \mathrm{MHz},\left[\mathrm{D}_{6}\right] \mathrm{DMSO}, 25^{\circ} \mathrm{C}, \mathrm{TMS}\right)$ : $\delta=168.9,164.5,154.9,154.2,137.8,129.9,127.9$ (2C), 126.4, 126.4, 125.5, $121.1(2 \mathrm{C}), 120.5$,

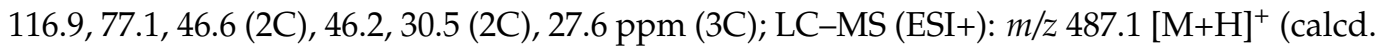
$m / z=486.1$ for $\mathrm{C}_{24} \mathrm{H}_{27} \mathrm{ClN}_{4} \mathrm{O}_{3} \mathrm{~S}$ ).

4-(N-Boc- $N$-Methylamino)-1-(6-((4-chlorophenyl)carbamoyl)benzo[d]thiazol-2-yl)piperidine (8j): The product was purified using column chromatography (mobile phase: DCM:MeOH = 20:1). Yield: $155 \mathrm{mg}$ (50\%); off-white amorphous powder; $\mathrm{R}_{\mathrm{f}}(\mathrm{DCM}: \mathrm{MeOH}=20: 1)=$ 0.12; ${ }^{1} \mathrm{H}$ NMR (400 MHz, [D 6 ]DMSO, $\left.25^{\circ} \mathrm{C}, \mathrm{TMS}\right): \delta=10.29$ (s, 1H, Ar-NH-COR), $8.38(\mathrm{~d}$, $\left.J=1.9 \mathrm{~Hz}, 1 \mathrm{H}, \mathrm{Ar}-H_{7}\right), 7.90\left(\mathrm{dd}, J_{1}=8.5 \mathrm{~Hz}, J_{2}=1.9 \mathrm{~Hz}, 1 \mathrm{H}, \mathrm{Ar}-H_{5}\right), 7.85-7.79(\mathrm{~m}, 2 \mathrm{H}, 2 \times$ Ar- H), $7.52\left(\mathrm{~d}, J=8.5 \mathrm{~Hz}, 1 \mathrm{H}, \mathrm{Ar}-\mathrm{H}_{4}\right), 7.44-7.36(\mathrm{~m}, 2 \mathrm{H}, 2 \times \mathrm{Ar}-\mathrm{H}), 4.24-3.96(\mathrm{~m}, 3 \mathrm{H}, 3 \times$ piperidine- $H), 3.31-3.23(\mathrm{~m}, 2 \mathrm{H}, 2 \times$ piperidine- $H), 2.67\left(\mathrm{~s}, 3 \mathrm{H}, \mathrm{N}-\mathrm{CH}_{3}\right) 1.83-1.65(\mathrm{~m}, 4 \mathrm{H}, 4$ $\times$ piperidine- $H), 1.41 \mathrm{ppm}\left(\mathrm{s}, 9 \mathrm{H}, \mathrm{COC}\left(\mathrm{CH}_{3}\right)_{3}\right) ; \mathrm{LC}-\mathrm{MS}(\mathrm{ESI}+): \mathrm{m} / z 501.2[\mathrm{M}+\mathrm{H}]^{+}$(calcd. $m / z=500.2$ for $\mathrm{C}_{25} \mathrm{H}_{29} \mathrm{ClN}_{4} \mathrm{O}_{3} \mathrm{~S}$ ).

2-(4-Carbamoylpiperidin-1-yl)-N-(4-chlorophenyl)benzo[ $d$ ] thiazole-6-carboxamide (8k): The product was purified using column chromatography (mobile phase: DCM:MeOH = 17.5:1). Yield: $31 \mathrm{mg}(23 \%)$; white amorphous powder; $\mathrm{R}_{\mathrm{f}}(\mathrm{DCM}: \mathrm{MeOH}=17: 1)=0.08 ;{ }^{1} \mathrm{H}$ $\operatorname{NMR}\left(400 \mathrm{MHz},\left[\mathrm{D}_{6}\right] \mathrm{DMSO}, 25^{\circ} \mathrm{C}, \mathrm{TMS}\right): \delta=10.29$ (s, 1H, Ar-NH-COR), 8.38 (d, J = 1.9 Hz, $\left.1 \mathrm{H}, \mathrm{Ar}-H_{7}\right), 7.90\left(\mathrm{dd}, J_{1}=8.5 \mathrm{~Hz}, J_{2}=1.9 \mathrm{~Hz}, 1 \mathrm{H}, \mathrm{Ar}-H_{5}\right), 7.85-7.79(\mathrm{~m}, 2 \mathrm{H}, 2 \times \mathrm{Ar}-\mathrm{H}), 7.52$ $\left(\mathrm{d}, J=8.5 \mathrm{~Hz}, 1 \mathrm{H}, \mathrm{Ar}-H_{4}\right), 7.43-7.38(\mathrm{~m}, 2 \mathrm{H}, 2 \times \mathrm{Ar}-\mathrm{H}), 7.36\left(\mathrm{~s}, 1 \mathrm{H}, \mathrm{CH}-\mathrm{CONH}_{a}\right), 6.87(\mathrm{~s}, 1 \mathrm{H}$, $\left.\mathrm{CH}-\mathrm{CONH}_{b}\right), 4.08(\mathrm{~d}, J=13.0 \mathrm{~Hz}, 2 \mathrm{H}, 2 \times$ piperidine- $H), 3.29-3.21(\mathrm{~m}, 2 \mathrm{H}, 2 \times$ piperidine$H), 2.45-2.39(\mathrm{~m}, 1 \mathrm{H}$, piperidine- $H), 1.90-1.79(\mathrm{~m}, 2 \mathrm{H}, 2 \times$ piperidine- $H), 1.68-1.56 \mathrm{ppm}$ $(\mathrm{m}, 2 \mathrm{H}, 2 \times$ piperidine- $H) ;{ }^{13} \mathrm{C}\left(101 \mathrm{MHz},\left[\mathrm{D}_{6}\right] \mathrm{DMSO}, 25^{\circ} \mathrm{C}, \mathrm{TMS}\right): \delta=176.1,170.2,165.6$, 155.9, 138.9, 130.8, 129.0 (2C), 127.5, 127.4, 126.6, 122.2 (2C), 121.6, 118.0, 48.4, 41.5 (2C), $28.2 \mathrm{ppm}\left(2 \mathrm{C}\right.$ ); HRMS (ESI+) $m / z$ calcd. for $\mathrm{C}_{20} \mathrm{H}_{19} \mathrm{ClN}_{4} \mathrm{O}_{2} \mathrm{~S}+\mathrm{H}^{+}: 415.0990[\mathrm{M}+\mathrm{H}]^{+}$: found 415.0966; HPLC: $\mathrm{t}_{\mathrm{r}}=5.41 \mathrm{~min}(99.0 \%$ at $254 \mathrm{~nm})$. 
2-(3-Carbamoylpiperidin-1-yl)-N-(4-chlorophenyl)benzo[d]thiazole-6-carboxamide (81): The product was purified using column chromatography (mobile phase: DCM:MeOH = 15:1). Yield: $73 \mathrm{mg}(65 \%)$; white amorphous powder; $\mathrm{R}_{\mathrm{f}}(\mathrm{DCM}: \mathrm{MeOH}=9: 1)=0.27 ;{ }^{1} \mathrm{H}$ $\operatorname{NMR}\left(400 \mathrm{MHz},\left[\mathrm{D}_{6}\right.\right.$ ]DMSO, $\left.25^{\circ} \mathrm{C}, \mathrm{TMS}\right): \delta=10.29$ (s, $\left.1 \mathrm{H}, \mathrm{Ar}-\mathrm{NH}-\mathrm{COR}\right), 8.38(\mathrm{~s}, 1 \mathrm{H}, \mathrm{Ar}-\mathrm{H})$, $7.90(\mathrm{~d}, J=8.5 \mathrm{~Hz}, 1 \mathrm{H}, \mathrm{Ar}-H), 7.82(\mathrm{~d}, J=8.4 \mathrm{~Hz}, 2 \mathrm{H}, 2 \times \mathrm{Ar}-H), 7.52(\mathrm{~d}, J=8.5 \mathrm{~Hz}, 1 \mathrm{H}$, Ar- $H), 7.46\left(\mathrm{~s}, 1 \mathrm{H}, \mathrm{CO}-\mathrm{NH}_{a}\right), 7.41(\mathrm{~d}, J=8.4 \mathrm{~Hz}, 2 \mathrm{H}, 2 \times \mathrm{Ar}-H), 6.98\left(\mathrm{~s}, 1 \mathrm{H}, \mathrm{CO}-\mathrm{NH}_{b}\right)$, 4.15-4.07 (m, 1H, piperidine- $H), 4.00-3.93(\mathrm{~m}, 1 \mathrm{H}$, piperidine- $H), 3.30-3.19(\mathrm{~m}, 2 \mathrm{H}, 2 \times$ piperidine- $H), 2.00-1.92(\mathrm{~m}, 1 \mathrm{H}$, piperidine- $H), 1.85-1.77(\mathrm{~m}, 1 \mathrm{H}$, piperidine- $H), 1.71-1.50$ ppm $(\mathrm{m}, 3 \mathrm{H}, 3 \times$ piperidine- $H) ;{ }^{13} \mathrm{C}\left(101 \mathrm{MHz},\left[\mathrm{D}_{6}\right] \mathrm{DMSO}, 25^{\circ} \mathrm{C}, \mathrm{TMS}\right): \delta=174.8,170.2$, 165.6, 155.9, 138.9, 130.8, 129.0 (2C), 127.5, 127.4, 126.6, 122.2 (2C), 121.6, 118.0, 51.0, 49.2, 41.8, 27.8, 24.3 ppm; HRMS (ESI+) $m / z$ calcd. for $\mathrm{C}_{20} \mathrm{H}_{19} \mathrm{ClN}_{4} \mathrm{O}_{2} \mathrm{~S}+\mathrm{H}^{+}: 415.0990[M+\mathrm{H}]^{+}$: found 415.0985 ; HPLC: $\mathrm{t}_{\mathrm{r}}=5.54 \mathrm{~min}(99.9 \%$ at $254 \mathrm{~nm})$.

2-(4-Hydroxypiperidin-1-yl)- $\mathrm{N}$-(4-chlorophenyl)benzo[d]thiazole-6-carboxamide (8m): The product was purified using column chromatography (mobile phase: EtOAc:Hex = 2:1). Yield: $49 \mathrm{mg}(46 \%)$; white amorphous powder; $\mathrm{R}_{\mathrm{f}}(\mathrm{DCM}: \mathrm{MeOH}=20: 1)=0.07 ;{ }^{1} \mathrm{H}$ NMR (400 MHz, [D $\mathrm{D}_{6}$ DMSO, $\left.25^{\circ} \mathrm{C}, \mathrm{TMS}\right): \delta=10.28(\mathrm{~s}, 1 \mathrm{H}, \mathrm{Ar}-\mathrm{NH}-\mathrm{COR}), 8.37(\mathrm{~d}, J=1.8 \mathrm{~Hz}, 1 \mathrm{H}$, Ar- $\left.H_{7}\right), 7.89\left(\mathrm{dd}, J_{1}=8.5 \mathrm{~Hz}, J_{2}=1.8 \mathrm{~Hz}, 1 \mathrm{H}, \mathrm{Ar}-\mathrm{H}_{5}\right), 7.86-7.79(\mathrm{~m}, 2 \mathrm{H}, 2 \times \mathrm{Ar}-\mathrm{H}), 7.50$ $\left(\mathrm{d}, J=8.5 \mathrm{~Hz}, 1 \mathrm{H}, \mathrm{Ar}-H_{4}\right), 7.44-7.37(\mathrm{~m}, 2 \mathrm{H}, 2 \times \mathrm{Ar}-\mathrm{H}), 4.88(\mathrm{~d}, J=4.1 \mathrm{~Hz}, 1 \mathrm{H}, \mathrm{CH}-\mathrm{OH})$, 3.94-3.83 (m, $2 \mathrm{H}, 2 \times$ piperidine- $H), 3.84-3.76(\mathrm{~m}, 1 \mathrm{H}$, piperidine- $H), 3.46-3.37(\mathrm{~m}, 2 \mathrm{H}, 2 \times$ piperidine- $H), 1.93-1.80(\mathrm{~m}, 2 \mathrm{H}, 2 \times$ piperidine- $H), 1.56-1.41 \mathrm{ppm}(\mathrm{m}, 2 \mathrm{H}, 2 \times$ piperidine$H) ;{ }^{13} \mathrm{C}\left(101 \mathrm{MHz},\left[\mathrm{D}_{6}\right] \mathrm{DMSO}, 25{ }^{\circ} \mathrm{C}\right.$, TMS $): \delta=170.1,165.6,156.0,138.9,130.9,129.0(2 \mathrm{C})$, 127.4, 126.6, 122.2 (2C), 121.6, 118.0, 65.5, 46.41 (2C), 33.81 (2C) ppm; HRMS (ESI+) $\mathrm{m} / \mathrm{z}$ calcd. for $\mathrm{C}_{19} \mathrm{H}_{18} \mathrm{ClN}_{3} \mathrm{O}_{2} \mathrm{~S}+\mathrm{H}^{+}$: $388.0881[\mathrm{M}+\mathrm{H}]^{+}$: found 388.0885; HPLC: $\mathrm{t}_{\mathrm{r}}=6.00 \mathrm{~min}$ $(96.2 \%$ at $254 \mathrm{~nm})$.

2-(4-Methylpiperidin-1-yl)- $N$-(4-chlorophenyl)benzo[d]thiazole-6-carboxamide (8n): The product was purified using column chromatography (mobile phase: DCM:MeOH $=67: 1$ ). Yield: $27 \mathrm{mg}$ (29\%); white amorphous powder; $\mathrm{R}_{\mathrm{f}}(\mathrm{DCM}: \mathrm{MeOH}=66: 1)=0.12 ;{ }^{1} \mathrm{H} \mathrm{NMR}$ (400 MHz, [D $\mathrm{D}_{6}$ DMSO, $\left.25^{\circ} \mathrm{C}, \mathrm{TMS}\right): \delta=10.28(\mathrm{~s}, 1 \mathrm{H}, \mathrm{Ar}-\mathrm{NH}-\mathrm{COR}), 8.37(\mathrm{~d}, J=1.9 \mathrm{~Hz}, 1 \mathrm{H}$, Ar- $\left.H_{7}\right), 7.89\left(\mathrm{dd}, J_{1}=8.5 \mathrm{~Hz}, J_{2}=1.9 \mathrm{~Hz}, 1 \mathrm{H}, \mathrm{Ar}-H_{5}\right), 7.85-7.78(\mathrm{~m}, 2 \mathrm{H}, 2 \times \mathrm{Ar}-H), 7.50(\mathrm{~d}$, $\left.J=8.5 \mathrm{~Hz}, 1 \mathrm{H}, \mathrm{Ar}-\mathrm{H}_{4}\right), 7.44-7.38(\mathrm{~m}, 2 \mathrm{H}, 2 \times \mathrm{Ar}-\mathrm{H}), 4.11-4.02(\mathrm{~m}, 2 \mathrm{H}, 2 \times$ piperidine- $H)$, 3.25-3.17 (m, 2H, $2 \times$ piperidine- $H), 1.80-1.62(\mathrm{~m}, 3 \mathrm{H}, 3 \times$ piperidine- $H), 1.28-1.14(\mathrm{~m}, 2 \mathrm{H}$, $2 \times$ piperidine- $H), 0.96 \mathrm{ppm}\left(\mathrm{d}, J=6.4 \mathrm{~Hz}, 3 \mathrm{H}, \mathrm{CH}_{3}\right) ;{ }^{13} \mathrm{C}\left(101 \mathrm{MHz},\left[\mathrm{D}_{6}\right] \mathrm{DMSO}, 25^{\circ} \mathrm{C}\right.$, TMS): $\delta=170.1,165.6,156.0,138.9,130.8,128.9(2 \mathrm{C}), 127.4,127.4,126.6,122.2(2 \mathrm{C}), 121.5$, $117.9,49.0$ (2C), 33.5 (2C), 30.5, 22.0 ppm; HRMS (ESI+) $m / z$ calcd. for $\mathrm{C}_{20} \mathrm{H}_{20} \mathrm{~N}_{3} \mathrm{OS}+\mathrm{H}^{+}$: $386.1088[\mathrm{M}+\mathrm{H}]^{+}$: found 386.1083; HPLC: $\mathrm{t}_{\mathrm{r}}=7.49 \mathrm{~min}(99.4 \%$ at $254 \mathrm{~nm})$.

\section{General procedure for the synthesis of compounds $9 a-j$}

Acidolysis was performed in the same manner as described for the synthesis of compounds $5 \mathbf{a}-\mathbf{m}$.

1-N-(6-((4-Chlorophenyl)carbamoyl)benzo[d]thiazol-2-yl)1,3-diaminopropane (9a): Yield: $29 \mathrm{mg}(62 \%)$; off-white amorphous powder; $\mathrm{R}_{\mathrm{f}}(\mathrm{DCM}: \mathrm{MeOH}=9: 1)=0.0 ;{ }^{1} \mathrm{H}$ NMR $(400 \mathrm{MHz}$, [D $\mathrm{D}_{6}$ ]DMSO, $\left.25{ }^{\circ} \mathrm{C}, \mathrm{TMS}\right): \delta=10.25(\mathrm{~s}, 1 \mathrm{H}, \mathrm{Ar}-\mathrm{NH}-\mathrm{COR}), 8.28(\mathrm{~d}, J=1.8 \mathrm{~Hz}, 1 \mathrm{H}, \mathrm{Ar}-\mathrm{H})$, 7.88-7.78 (m, 3H, $3 \times \mathrm{Ar}-\mathrm{H}), 7.48-7.36(\mathrm{~m}, 3 \mathrm{H}, 3 \times \mathrm{Ar}-\mathrm{H}), 3.44\left(\mathrm{t}, J=6.8 \mathrm{~Hz}, 2 \mathrm{H}, \mathrm{N}-\mathrm{CH}_{2}-\right.$ $\left.\mathrm{CH}_{2}\right), 2.63\left(\mathrm{t}, J=6.8 \mathrm{~Hz}, 2 \mathrm{H}, \mathrm{N}-\mathrm{CH}_{2}-\mathrm{CH}_{2}\right), 1.66 \mathrm{ppm}(\mathrm{p}, J=6.8 \mathrm{~Hz}, 2 \mathrm{H})$, not visible $(\mathrm{NH}$ and $\left.\mathrm{NH}_{2}\right) ;{ }^{13} \mathrm{C}\left(101 \mathrm{MHz},\left[\mathrm{D}_{6}\right.\right.$ ]DMSO, $\left.25^{\circ} \mathrm{C}, \mathrm{TMS}\right): \delta=168.8,165.7,156.0,138.9,130.7$, 128.9 (2C), 127.4, 127.2, 126.2, 122.1 (2C), 121.3, 117.5, 42.4 (2C), 33.0 ppm; HRMS (ESI+) $m / z$ calcd. for $\mathrm{C}_{17} \mathrm{H}_{17} \mathrm{ClN}_{4} \mathrm{OS}+\mathrm{H}^{+}: 361.0884[M+\mathrm{H}]^{+}$: found 361.0877; HPLC: $\mathrm{t}_{\mathrm{r}}=4.40 \mathrm{~min}$ $(99.8 \%$ at $254 \mathrm{~nm})$.

3-Amino-1-(6-((4-chlorophenyl)carbamoyl)benzo[d]thiazol-2-yl)piperidine (9b): Yield: $39 \mathrm{mg}(89 \%)$; off-white amorphous powder; $\mathrm{R}_{\mathrm{f}}(\mathrm{DCM}: \mathrm{MeOH}=4: 1)=0.0 ;{ }^{1} \mathrm{H} \mathrm{NMR}(400 \mathrm{MHz}$, [D $\mathrm{D}_{6}$ DMSO, $\left.25^{\circ} \mathrm{C}, \mathrm{TMS}\right): \delta=10.27(\mathrm{~s}, 1 \mathrm{H}, \mathrm{Ar}-\mathrm{NH}-\mathrm{COR}), 8.36\left(\mathrm{~d}, \mathrm{~J}=1.8 \mathrm{~Hz}, 1 \mathrm{H}, \mathrm{Ar}-\mathrm{H}_{7}\right), 7.89$ $\left(\mathrm{dd}, J_{1}=8.5 \mathrm{~Hz}, J_{2}=1.8 \mathrm{~Hz}, 1 \mathrm{H}, \mathrm{Ar}-H_{5}\right), 7.85-7.78(\mathrm{~m}, 2 \mathrm{H}, 2 \times \mathrm{Ar}-H), 7.49(\mathrm{~d}, J=8.5 \mathrm{~Hz}$, $\left.1 \mathrm{H}, \mathrm{Ar}-\mathrm{H}_{4}\right), 7.43-7.38(\mathrm{~m}, 2 \mathrm{H}, 2 \times \mathrm{Ar}-\mathrm{H}), 3.95\left(\mathrm{dd}, J_{1}=29.1 \mathrm{~Hz}, J_{2}=12.8 \mathrm{~Hz}, 2 \mathrm{H}, \mathrm{CH}-\right.$ 
$\left.\mathrm{NH}_{2}\right), 3.23-3.14(\mathrm{~m}, 1 \mathrm{H}$, piperidine- $H), 2.93-2.86(\mathrm{~m}, 1 \mathrm{H}$, piperidine- $H), 2.79-2.70(\mathrm{~m}$, $1 \mathrm{H}$, piperidine- $H), 1.93-1.84(\mathrm{~m}, 1 \mathrm{H}$, piperidine $-H), 1.83-1.70(\mathrm{~m}, 3 \mathrm{H}, 3 \times$ piperidine- $H)$, $1.60-1.46(\mathrm{~m}, 1 \mathrm{H}$, piperidine- $H), 1.34-1.21 \mathrm{ppm}(\mathrm{m}, 1 \mathrm{H}$, piperidine- $H) ;{ }^{13} \mathrm{C}(101 \mathrm{MHz}$, [D $\mathrm{D}_{6}$ ]DMSO, $\left.25{ }^{\circ} \mathrm{C}, \mathrm{TMS}\right): \delta=170.2,165.6,156.0,138.9,130.8,129.0(2 \mathrm{C}), 127.4,127.3$, 126.6, 122.2 (2C), 121.5, 117.9, 57.1, 48.9, 47.9, 33.7, 23.7 ppm; HRMS (ESI+) $m / z$ calcd. for $\mathrm{C}_{19} \mathrm{H}_{19} \mathrm{ClN}_{4} \mathrm{OS}+\mathrm{H}^{+}: 387.1041[M+\mathrm{H}]^{+}$: found 387.1017; HPLC: $\mathrm{t}_{\mathrm{r}}=5.43 \mathrm{~min}(97.9 \%$ at $254 \mathrm{~nm}$ ).

3-(S)-Amino-1-(6-((4-chlorophenyl)carbamoyl)benzo[d]thiazol-2-yl)pyrrolidine (9c): Yield: $47 \mathrm{mg}(80 \%)$; off-white amorphous powder; $\mathrm{R}_{\mathrm{f}}(\mathrm{DCM}: \mathrm{MeOH}=9: 1)=0.03 ;{ }^{1} \mathrm{H}$ NMR (400 MHz, [D $\mathrm{D}_{6}$ ]DMSO, $25^{\circ} \mathrm{C}$, TMS): $\delta=10.27$ (s, $\left.1 \mathrm{H}, \mathrm{Ar}-\mathrm{NH}-\mathrm{COR}\right), 8.37(\mathrm{~d}, J=1.8 \mathrm{~Hz}$, $\left.1 \mathrm{H}, \mathrm{Ar}-H_{7}\right), 7.88\left(\mathrm{dd}, J_{1}=8.5 \mathrm{~Hz}, J_{2}=1.9 \mathrm{~Hz}, 1 \mathrm{H}, \mathrm{Ar}-H_{5}\right), 7.84-7.78(\mathrm{~m}, 2 \mathrm{H}, 2 \times \mathrm{Ar}-\mathrm{H})$, $7.52\left(\mathrm{~d}, J=8.5 \mathrm{~Hz}, 1 \mathrm{H}, \mathrm{Ar}-\mathrm{H}_{4}\right), 7.44-7.37(\mathrm{~m}, 2 \mathrm{H}, 2 \times \mathrm{Ar}-\mathrm{H}), 3.73-3.46\left(\mathrm{~m}, 4 \mathrm{H}, \mathrm{CH}-\mathrm{NH}_{2}\right.$ $+2 \times$ pyrrolidine- $H), 3.29-3.15(\mathrm{~m}, 1 \mathrm{H}$, pyrrolidine- $H), 2.17-2.04(\mathrm{~m}, 1 \mathrm{H}$, pyrrolidine- $H)$, 1.90-1.74 ppm (m, 3H, $3 \times$ pyrrolidine- $H) ;{ }^{13} \mathrm{C}\left(101 \mathrm{MHz},\left[\mathrm{D}_{6}\right] \mathrm{DMSO}, 25^{\circ} \mathrm{C}, \mathrm{TMS}\right): \delta=167.0$, $165.7,156.4,138.9,130.9,129.0(2 \mathrm{C}), 127.4,126.9,126.5,122.2(2 \mathrm{C}), 121.7,117.7,58.3,51.4,48.5$, $34.5 \mathrm{ppm} ;[\alpha]_{\mathrm{D}}{ }^{25}=11.5$ (c = 0.77 in DMF); HRMS (ESI+) $\mathrm{m} / z$ calcd. for $\mathrm{C}_{18} \mathrm{H}_{17} \mathrm{ClN}_{4} \mathrm{OS}+\mathrm{H}^{+}$: $373.0884[\mathrm{M}+\mathrm{H}]^{+}$: found 373.0878; HPLC: $\mathrm{t}_{\mathrm{r}}=4.41 \mathrm{~min}(98.9 \%$ at $254 \mathrm{~nm})$.

3-(R)-Amino-1-(6-((4-chlorophenyl)carbamoyl)benzo[d]thiazol-2-yl)pyrrolidine (9d): Yield: $41 \mathrm{mg}(75 \%)$; off-white amorphous powder; $\mathrm{R}_{\mathrm{f}}(\mathrm{DCM}: \mathrm{MeOH}=9: 1)=0.0 ;{ }^{1} \mathrm{H}$ NMR $(400 \mathrm{MHz}$, [D $\mathrm{D}_{6}$ ]DMSO, $25^{\circ} \mathrm{C}$, TMS): $\delta=10.27(\mathrm{~s}, 1 \mathrm{H}, \mathrm{Ar}-\mathrm{NH}-\mathrm{COR}), 8.37\left(\mathrm{~d}, J=1.8 \mathrm{~Hz}, 1 \mathrm{H}, \mathrm{Ar}-\mathrm{H}_{7}\right), 7.88$ $\left(\mathrm{dd}, J_{1}=8.5 \mathrm{~Hz}, J_{2}=1.9 \mathrm{~Hz}, 1 \mathrm{H}, \mathrm{Ar}-H_{5}\right), 7.85-7.79(\mathrm{~m}, 2 \mathrm{H}, 2 \times \mathrm{Ar}-H), 7.52(\mathrm{~d}, J=8.5 \mathrm{~Hz}, 1 \mathrm{H}$, Ar- $\left.H_{4}\right), 7.44-7.37(\mathrm{~m}, 2 \mathrm{H}, 2 \times \mathrm{Ar}-\mathrm{H}), 3.73-3.48\left(\mathrm{~m}, 4 \mathrm{H}, \mathrm{CH}-\mathrm{NH}_{2}\right.$ and $2 \times$ pyrrolidine- $\left.\mathrm{H}\right)$, 3.27-3.18 $(\mathrm{m}, 1 \mathrm{H}$, pyrrolidine- $H), 2.16-2.07(\mathrm{~m}, 1 \mathrm{H}$, pyrrolidine- $H), 1.96-1.74 \mathrm{ppm}(\mathrm{m}, 3 \mathrm{H}$, $3 \times$ pyrrolidine- $H) ;{ }^{13} \mathrm{C}\left(101 \mathrm{MHz},\left[\mathrm{D}_{6}\right.\right.$ ]DMSO, $25^{\circ} \mathrm{C}$, TMS $): \delta=167.0,165.7,156.4,138.9$, $130.9,129.0$ (2C), 127.4, 126.9, 126.5, 122.2 (2C), 121.7, 117.7, 58.2, 51.4, 48.5, 34.4 ppm; $[\alpha]_{\mathrm{D}}{ }^{25}=-11.5(\mathrm{c}=0.77$ in DMF);HRMS (ESI +$) \mathrm{m} / z$ calcd. for $\mathrm{C}_{18} \mathrm{H}_{17} \mathrm{ClN}_{4} \mathrm{OS}+\mathrm{H}^{+}: 373.0884$ $[\mathrm{M}+\mathrm{H}]^{+}$: found 373.0879 ; HPLC: $\mathrm{t}_{\mathrm{r}}=4.41 \mathrm{~min}(98.7 \%$ at $254 \mathrm{~nm})$.

4-Aminomethyl-1-(6-((4-chlorophenyl)carbamoyl)benzo[ $d]$ thiazol-2-yl)piperidin (9e): Yield: $45 \mathrm{mg}$ (94\%); off-white amorphous powder; $\mathrm{R}_{\mathrm{f}}(\mathrm{DCM}: \mathrm{MeOH}=9: 1)=0.0 ;{ }^{1} \mathrm{H}$ NMR (400 MHz, [D ${ }_{6}$ ]DMSO, $\left.25^{\circ} \mathrm{C}, \mathrm{TMS}\right): \delta=10.28(\mathrm{~s}, 1 \mathrm{H}, \mathrm{Ar}-\mathrm{NH}-\mathrm{COR}), 8.36(\mathrm{~d}, J=1.8 \mathrm{~Hz}, 1 \mathrm{H}$, Ar- $\left.H_{7}\right), 7.89\left(\mathrm{dd}, J_{1}=8.5 \mathrm{~Hz}, J_{2}=1.8 \mathrm{~Hz}, 1 \mathrm{H}, \mathrm{Ar}-H_{5}\right), 7.84-7.80(\mathrm{~m}, 2 \mathrm{H}, 2 \times \mathrm{Ar}-H), 7.50(\mathrm{~d}$, $\left.J=8.5 \mathrm{~Hz}, 1 \mathrm{H}, \mathrm{Ar}-\mathrm{H}_{4}\right), 7.43-7.38(\mathrm{~m}, 2 \mathrm{H}, 2 \times \mathrm{Ar}-\mathrm{H}), 4.13-4.05\left(\mathrm{~m}, 2 \mathrm{H}, \mathrm{CH}_{2}-\mathrm{NH}_{2}\right), 3.19(\mathrm{td}$, $\left.J_{1}=12.7 \mathrm{~Hz}, J_{2}=2.6 \mathrm{~Hz}, 2 \mathrm{H}, \mathrm{CH}-\mathrm{CH}_{2}-\mathrm{NH}_{2}\right), 2.47-2.44(\mathrm{~m}, 2 \mathrm{H}, 2 \times$ piperidine- $H), 1.87-1.80$ $(\mathrm{m}, 2 \mathrm{H}, 2 \times$ piperidine- $H), 1.59-1.40(\mathrm{~m}, 3 \mathrm{H}, 3 \times$ piperidine- $H), 1.26-1.12 \mathrm{ppm}(\mathrm{m}, 2 \mathrm{H}$, $2 \times$ piperidine- $H) ;{ }^{13} \mathrm{C}\left(101 \mathrm{MHz},\left[\mathrm{D}_{6}\right] \mathrm{DMSO}, 25^{\circ} \mathrm{C}, \mathrm{TMS}\right): \delta=170.2,165.6,156.1,138.9$, $130.8,129.0$ (2C), 127.4, 127.4, 126.6, 122.2 (2C), 121.5, 117.9, 49.0 (2C), 47.7, 29.5 ppm (3C); HRMS (ESI+) $m / z$ calcd. for $\mathrm{C}_{20} \mathrm{H}_{21} \mathrm{ClN}_{4} \mathrm{OS}+\mathrm{H}^{+}: 401.1197[\mathrm{M}+\mathrm{H}]^{+}$: found 401.1192; HPLC: $\mathrm{t}_{\mathrm{r}}=5.49 \mathrm{~min}(97.7 \%$ at $254 \mathrm{~nm})$.

4-((6-((4-Chlorophenyl)carbamoyl)benzo[d]thiazol-2-yl)amino)piperidine (9f): Yield: $39 \mathrm{mg}$ $(82 \%)$; off-white amorphous powder; $\mathrm{R}_{\mathrm{f}}(\mathrm{DCM}: \mathrm{MeOH}=9: 1)=0.0 ;{ }^{1} \mathrm{H} \mathrm{NMR}(400 \mathrm{MHz}$, [D ${ }_{6}$ ]DMSO, $\left.25^{\circ} \mathrm{C}, \mathrm{TMS}\right): \delta=10.24(\mathrm{~s}, 1 \mathrm{H}, \mathrm{Ar}-\mathrm{NH}-\mathrm{COR}), 8.34(\mathrm{~d}, J=7.3 \mathrm{~Hz}, 1 \mathrm{H}, \mathrm{Ar}-\mathrm{NH}-$ $\mathrm{CH}), 8.27(\mathrm{~d}, J=1.7 \mathrm{~Hz}, 1 \mathrm{H}, \mathrm{Ar}-H), 7.87-7.79(\mathrm{~m}, 3 \mathrm{H}, 3 \times \mathrm{Ar}-H), 7.45(\mathrm{~d}, J=8.4 \mathrm{~Hz}, 1 \mathrm{H}$, Ar- $H), 7.42-7.37(\mathrm{~m}, 2 \mathrm{H}, 2 \times \mathrm{Ar}-H), 3.82-3.76(\mathrm{~m}, 1 \mathrm{H}$, piperidine- $H), 2.99-2.90(\mathrm{~m}, 2 \mathrm{H}$, $2 \times$ piperidine- $H), 1.98-1.88(\mathrm{~m}, 2 \mathrm{H}, 2 \times$ piperidine- $H), 1.34 \mathrm{ppm}\left(\mathrm{ddd}, J_{1}=14.9 \mathrm{~Hz}\right.$, $J_{2}=11.7 \mathrm{~Hz}, J_{3}=3.8 \mathrm{~Hz}, 2 \mathrm{H}, 2 \times$ piperidine $\left.-H\right)$, not visible $(2 \times$ piperidine $-H$ and $\mathrm{NH}) ;{ }^{13} \mathrm{C}$ (101 MHz, [D $\mathrm{D}_{6}$ DMSO, $\left.25^{\circ} \mathrm{C}, \mathrm{TMS}\right): \delta=167.6,165.7,156.1,138.9,130.7,128.9(2 \mathrm{C}), 127.4$, 127.2, 126.2, 122.1 (2C), 121.3, 117.5, 52.5, 45.3 (2C), 33.4 ppm (2C); HRMS (ESI+) $\mathrm{m} / z$ calcd. for $\mathrm{C}_{19} \mathrm{H}_{19} \mathrm{ClN}_{4} \mathrm{OS}+\mathrm{H}^{+}$: $387.1041[M+\mathrm{H}]^{+}$: found 387.1033; HPLC: $\mathrm{t}_{\mathrm{r}}=4.45 \mathrm{~min}(95.1 \%$ at $254 \mathrm{~nm}$ ).

7-(6-((4-Chlorophenyl)carbamoyl)benzo[ $d$ ]thiazol-2-yl)-2,7-diazaspiro[4.4]nonane (9g): Yield: $68 \mathrm{mg}$ (85\%); off-white amorphous powder; $\mathrm{R}_{\mathrm{f}}(\mathrm{DCM}: \mathrm{MeOH}=9: 1)=0.0 ;{ }^{1} \mathrm{H}$ NMR $\left(400 \mathrm{MHz},\left[\mathrm{D}_{6}\right] \mathrm{DMSO}, 25^{\circ} \mathrm{C}, \mathrm{TMS}\right): \delta=10.27$ (s, $\left.1 \mathrm{H}, \mathrm{Ar}-\mathrm{NH}-\mathrm{COR}\right), 8.39$ (d, J = $1.8 \mathrm{~Hz}$, 
$\left.1 \mathrm{H}, \mathrm{Ar}-H_{7}\right), 7.89\left(\mathrm{dd}, J_{1}=8.5 \mathrm{~Hz}, J_{2}=1.8 \mathrm{~Hz}, 1 \mathrm{H}, \mathrm{Ar}-H_{5}\right), 7.84-7.79(\mathrm{~m}, 2 \mathrm{H}, 2 \times \mathrm{Ar}-H)$, $7.52\left(\mathrm{~d}, J=8.5 \mathrm{~Hz}, 1 \mathrm{H}, \mathrm{Ar}-\mathrm{H}_{4}\right), 7.43-7.37(\mathrm{~m}, 2 \mathrm{H}, 2 \times \mathrm{Ar}-\mathrm{H}), 3.69-3.40\left(\mathrm{~m}, 4 \mathrm{H}, 2 \times \mathrm{CH}_{2}\right)$, 2.94-2.86 (m, 2H, CH$), 2.81-2.70\left(\mathrm{~m}, 2 \mathrm{H}, \mathrm{CH}_{2}\right), 2.07-1.97\left(\mathrm{~m}, 2 \mathrm{H}, \mathrm{CH}_{2}\right), 1.81-1.68 \mathrm{ppm}(\mathrm{m}$, $\left.2 \mathrm{H}, \mathrm{CH}_{2}\right)$, not visible $(\mathrm{NH}) ;{ }^{13} \mathrm{C}\left(101 \mathrm{MHz},\left[\mathrm{D}_{6}\right] \mathrm{DMSO}, 25^{\circ} \mathrm{C}, \mathrm{TMS}\right): \delta=166.9,165.7,156.3$, $138.9,130.9,128.9$ (2C), 127.4, 127.0, 126.6, 122.2 (2C), 121.7, 117.8, 59.3, 55.6, 49.9, 49.4, 45.8, $35.9,35.5$ ppm; HRMS (ESI+) $m / z$ calcd. for $\mathrm{C}_{21} \mathrm{H}_{21} \mathrm{ClN}_{4} \mathrm{OS}+\mathrm{H}^{+}: 413.1197[\mathrm{M}+\mathrm{H}]^{+}$: found 413.1190; HPLC: $\mathrm{t}_{\mathrm{r}}=4.59 \mathrm{~min}(97.0 \%$ at $254 \mathrm{~nm})$.

5-(6-((4-Chlorophenyl)carbamoyl)benzo[ $d]$ thiazol-2-yl)hexahydropyrrolo[3,4-c]pyrrole (9h): Yield: $30 \mathrm{mg}$ (70\%); off-white amorphous powder; $\mathrm{R}_{\mathrm{f}}(\mathrm{DCM}: \mathrm{MeOH}=9: 1)=0.0 ;{ }^{1} \mathrm{H}$ NMR (400 MHz, [D 6 ]DMSO, $\left.25^{\circ} \mathrm{C}, \mathrm{TMS}\right): \delta=10.28$ (s, 1H, Ar-NH-COR), 8.38 (d, J = 1.9 Hz, $\left.1 \mathrm{H}, \mathrm{Ar}-H_{7}\right), 7.89\left(\mathrm{dd}, J_{1}=8.5 \mathrm{~Hz}, J_{2}=1.9 \mathrm{~Hz}, 1 \mathrm{H}, \mathrm{Ar}-H_{5}\right), 7.85-7.79(\mathrm{~m}, 2 \mathrm{H}, 2 \times \mathrm{Ar}-\mathrm{H})$, $7.53\left(\mathrm{~d}, J=8.5 \mathrm{~Hz}, 1 \mathrm{H}, \mathrm{Ar}-\mathrm{H}_{4}\right), 7.43-7.38(\mathrm{~m}, 2 \mathrm{H}, 2 \times \mathrm{Ar}-\mathrm{H}), 3.82-3.75(\mathrm{~m}, 2 \mathrm{H}, 2 \times \mathrm{CH})$, 3.39-3.37 (m, 2H, $2 \times \mathrm{CH}), 2.96-2.88(\mathrm{~m}, 4 \mathrm{H}, 4 \times \mathrm{CH}), 2.74-2.69 \mathrm{ppm}(\mathrm{m}, 2 \mathrm{H}, 2 \times \mathrm{CH})$, not visible $(\mathrm{NH}) ;{ }^{13} \mathrm{C}\left(101 \mathrm{MHz},\left[\mathrm{D}_{6}\right.\right.$ ]DMSO, $\left.25^{\circ} \mathrm{C}, \mathrm{TMS}\right): \delta=166.6,165.7,156.2,138.9,131.1$, 128.9 (2C), 127.4, 127.1, 126.5, 122.2 (2C), 121.7, 117.9, 55.3 (2C), 53.2 (2C), 43.8 ppm (2C); HRMS (ESI+) $m / z$ calcd. for $\mathrm{C}_{20} \mathrm{H}_{19} \mathrm{ClN}_{4} \mathrm{OS}+\mathrm{H}^{+}: 399.1040[M+\mathrm{H}]^{+}$: found 399.1034; HPLC: $\mathrm{t}_{\mathrm{r}}=4.47 \mathrm{~min}(98.8 \%$ at $254 \mathrm{~nm})$.

4-Amino-1-(6-((4-chlorophenyl)carbamoyl)benzo[d]thiazol-2-yl)piperidine (9i): Yield: $32 \mathrm{mg}$ (73\%); off-white amorphous powder; $\mathrm{R}_{\mathrm{f}}(\mathrm{DCM}: \mathrm{MeOH}=9: 1)=0.03 ;{ }^{1} \mathrm{H} \mathrm{NMR}(400 \mathrm{MHz}$, [D 6 ]DMSO, $\left.25{ }^{\circ} \mathrm{C}, \mathrm{TMS}\right): \delta=10.28(\mathrm{~s}, 1 \mathrm{H}, \mathrm{Ar}-\mathrm{NH}-\mathrm{COR}), 8.37$ (d, J = $\left.1.8 \mathrm{~Hz}, 1 \mathrm{H}, \mathrm{Ar}-\mathrm{H}_{7}\right), 7.89$ $\left(\mathrm{dd}, J_{1}=8.5 \mathrm{~Hz}, J_{2}=1.8 \mathrm{~Hz}, 1 \mathrm{H}, \mathrm{Ar}-H_{5}\right), 7.85-7.79(\mathrm{~m}, 2 \mathrm{H}, 2 \times \mathrm{Ar}-H), 7.50(\mathrm{~d}, J=8.5 \mathrm{~Hz}$, $\left.1 \mathrm{H}, \mathrm{Ar}-\mathrm{H}_{4}\right), 7.43-7.37(\mathrm{~m}, 2 \mathrm{H}, 2 \times \mathrm{Ar}-\mathrm{H}), 3.99\left(\mathrm{~d}, \mathrm{~J}=13.1 \mathrm{~Hz}, 2 \mathrm{H}, \mathrm{CH}-\mathrm{NH}_{2}\right), 3.30-3.23(\mathrm{~m}$, $2 \mathrm{H}, 2 \times$ piperidine- $H), 2.91-2.83(\mathrm{~m}, 1 \mathrm{H}$, piperidine- $H), 1.87-1.64(\mathrm{~m}, 4 \mathrm{H}, 4 \times$ piperidine$H), 1.37-1.23 \mathrm{ppm}(\mathrm{m}, 2 \mathrm{H}, 2 \times$ piperidine- $H) ;{ }^{13} \mathrm{C}\left(101 \mathrm{MHz},\left[\mathrm{D}_{6}\right] \mathrm{DMSO}, 25{ }^{\circ} \mathrm{C}, \mathrm{TMS}\right)$ : $\delta=170.1,165.6,156.1,138.9,130.9,128.9$ (2C), 127.4, 127.4, 126.6, 122.2 (2C), 121.5, 117.9, 48.0, 47.6 (2C), $34.8 \mathrm{ppm}(2 \mathrm{C})$; HRMS (ESI+) $\mathrm{m} / z$ calcd. for $\mathrm{C}_{19} \mathrm{H}_{18} \mathrm{ClN}_{3} \mathrm{O}_{2} \mathrm{~S}+\mathrm{H}^{+}: 387.1041$ $[M+\mathrm{H}]^{+}:$found 387.1033 ; HPLC: $\mathrm{t}_{\mathrm{r}}=4.54 \mathrm{~min}(98.9 \%$ at $254 \mathrm{~nm})$.

4-(N-Methylamino)-1-(6-((4-chlorophenyl)carbamoyl)benzo[d]thiazol-2-yl)piperidine (9j): Yield: $89 \mathrm{mg}$ (74\%); off-white amorphous powder; $\mathrm{R}_{\mathrm{f}}(\mathrm{DCM}: \mathrm{MeOH}=9: 1)=0.0 ;{ }^{1} \mathrm{H}$ NMR (400 MHz, [D $\left.]_{\mathrm{DMSO}}, 25^{\circ} \mathrm{C}, \mathrm{TMS}\right): \delta=10.28$ (s, $\left.1 \mathrm{H}, \mathrm{Ar}-\mathrm{NH}-\mathrm{COR}\right), 8.37$ (d, J = $1.8 \mathrm{~Hz}, 1 \mathrm{H}$, Ar- $\left.H_{7}\right), 7.89\left(\mathrm{dd}, J_{1}=8.5 \mathrm{~Hz}, J_{2}=1.8 \mathrm{~Hz}, 1 \mathrm{H}, \mathrm{Ar}-H_{5}\right), 7.85-7.78(\mathrm{~m}, 2 \mathrm{H}, 2 \times \mathrm{Ar}-H), 7.50(\mathrm{~d}$, $\left.J=8.5 \mathrm{~Hz}, 1 \mathrm{H}, \mathrm{Ar}-H_{4}\right), 7.44-7.37(\mathrm{~m}, 2 \mathrm{H}, 2 \times \mathrm{Ar}-\mathrm{H}), 3.93-4.00(\mathrm{~m}, 2 \mathrm{H}, 2 \times$ piperidine- $H)$, 3.32-3.26 (m, 2H, $2 \times$ piperidine- $H), 2.63-2.54(\mathrm{~m}, 1 \mathrm{H}$, piperidine- $H), 2.30\left(\mathrm{~s}, 3 \mathrm{H}, \mathrm{NH}-\mathrm{CH}_{3}\right)$, 1.97-1.86 (m, 2H, $2 \times$ piperidine- $H), 1.83-1.67(\mathrm{~m}, 1 \mathrm{H}, \mathrm{NH}), 1.39-1.28 \mathrm{ppm}(\mathrm{m}, 2 \mathrm{H}, 2 \times$ piperidine- $H) ;{ }^{13} \mathrm{C}\left(101 \mathrm{MHz},\left[\mathrm{D}_{6}\right] \mathrm{DMSO}, 25{ }^{\circ} \mathrm{C}, \mathrm{TMS}\right): \delta=170.1,165.6,156.0,138.9,130.9$, 128.9 (2C), 127.4 , 127.4, 126.6, 122.2 (2C), 121.5, 118.0, 55.7, 47.3 (2C), 33.7, 31.3 ppm (2C); HRMS (ESI) $m / z$ calcd. for $\mathrm{C}_{20} \mathrm{H}_{21} \mathrm{ClN}_{4} \mathrm{OS}+\mathrm{H}^{+}: 401.1197[M+\mathrm{H}]^{+}$: found 401.1192; HPLC: $\mathrm{t}_{\mathrm{r}}=4.53 \mathrm{~min}(99.6 \%$ at $254 \mathrm{~nm})$.

4-(N,N-Dimethylamino)-1-(6-((4-chlorophenyl)carbamoyl)benzo[ $d]$ thiazol-2-yl)piperidine (10): Compound 9j (60 mg, $0.15 \mathrm{mmol})$ was dissolved in a mixture of DCM (5 mL) and $\mathrm{MeOH}(5 \mathrm{~mL})$. Formaldehyde $(\mathrm{aq})(56 \mu \mathrm{L}, 37 \%$ [w/w], $1.08 \mathrm{~g} / \mathrm{mL}, 0.75 \mathrm{mmol})$ and acetic acid $(8.6 \mu \mathrm{L}, 100 \%, 1.05 \mathrm{~g} / \mathrm{mL}, 0.15 \mathrm{mmol})$ were added. After $2 \mathrm{~h}, \mathrm{NaCNBH}_{3}(15 \mathrm{mg}$, $0.24 \mathrm{mmol}$ ) was added. The reaction mixture was stirred overnight at room temperature. The solvent was evaporated under reduced pressure and the residue was taken up in DCM $(30 \mathrm{~mL})$. The organic phase was washed with $1 \mathrm{M} \mathrm{NaOH}(3 \times 25 \mathrm{~mL})$, saturated $\mathrm{NaCl}$ $(25 \mathrm{~mL})$ and dried over $\mathrm{Na}_{2} \mathrm{SO}_{4}$. The solvent was evaporated under reduced pressure. Yield: $56 \mathrm{mg}$ (90\%); white amorphous powder; $\mathrm{R}_{\mathrm{f}}(\mathrm{DCM}: \mathrm{MeOH}=9: 1)=0.03 ;{ }^{1} \mathrm{H}$ NMR (400 MHz, [D 6 ]DMSO, $\left.25{ }^{\circ} \mathrm{C}, \mathrm{TMS}\right): \delta=10.29$ (s, 1H, Ar-NH-COR), 8.38 (d, J = 1.9 Hz, $\left.1 \mathrm{H}, \mathrm{Ar}-\mathrm{H}_{7}\right), 7.90\left(\mathrm{dd}, J_{1}=8.5 \mathrm{~Hz}, J_{2}=1.9 \mathrm{~Hz}, 1 \mathrm{H}, \mathrm{Ar}-\mathrm{H}_{5}\right), 7.88-7.78(\mathrm{~m}, 2 \mathrm{H}, 2 \times \mathrm{Ar}-\mathrm{H})$, $7.51\left(\mathrm{~d}, J=8.5 \mathrm{~Hz}, 1 \mathrm{H}, \mathrm{Ar}-H_{4}\right), 7.44-7.37(\mathrm{~m}, 2 \mathrm{H}, 2 \times \mathrm{Ar}-\mathrm{H}), 4.08(\mathrm{~d}, J=13 \mathrm{~Hz}, 2 \mathrm{H}, 2 \times$ piperidine- $H), 3.29-3.16(\mathrm{~m}, 2 \times$ piperidine- $H), 2.20\left(\mathrm{~s}, 6 \mathrm{H}, \mathrm{N}\left(\mathrm{CH}_{3}\right)_{2}\right), 1.92-1.84(\mathrm{~m}, 2 \mathrm{H}$, $2 \times$ piperidine- $H), 1.55-1.42 \mathrm{ppm}(\mathrm{m}, 2 \mathrm{H}, 2 \times$ piperidine- $H)$, covered with solvent $(1 \mathrm{H}$, piperidine- $H) ;{ }^{13} \mathrm{C}\left(101 \mathrm{MHz},\left[\mathrm{D}_{6}\right] \mathrm{DMSO}, 25{ }^{\circ} \mathrm{C}, \mathrm{TMS}\right): \delta=170.0,165.6,156.0,138.9,130.9$, 
128.9 (2C), 127.5, 127.4, 126.6, 122.2 (2C), 121.6, 118.0, 61.1, 48.0 (2C), 41.9 (2C), 27.9 ppm (2C); HRMS (ESI+) $m / z$ calcd. for $\mathrm{C}_{21} \mathrm{H}_{23} \mathrm{ClN}_{4} \mathrm{OS}+\mathrm{H}^{+}: 415.1354[M+\mathrm{H}]^{+}$: found 415.1346; HPLC: $\mathrm{t}_{\mathrm{r}}=5.02 \mathrm{~min}(96.9 \%$ at $254 \mathrm{~nm})$.

Ethyl 2-(4-(N-Boc-amino)piperidin-1-yl)benzo[d]thiazole-6-carboxylate (11): Ethyl 2bromobenzo[d]thiazole-6-carboxylate $(750 \mathrm{mg}, 2.62 \mathrm{mmol})$ and 4 -( $\mathrm{N}$-Boc-amino)piperidine $(1.31 \mathrm{~g}, 6.55 \mathrm{mmol})$ were dissolved in THF $(100 \mathrm{~mL})$. The reaction mixture was then stirred at r.t. overnight. The precipitate was filtered off and the solvent was evaporated under reduced pressure. The residue was taken up in ethyl acetate $(100 \mathrm{~mL})$ and washed with $1 \%$ $(w / v)$ citric acid $(3 \times 50 \mathrm{~mL})$ and saturated $\mathrm{NaCl}(50 \mathrm{~mL})$. The organic phase was dried over $\mathrm{Na}_{2} \mathrm{SO}_{4}$, filtered and the solvent was evaporated under reduced pressure. Yield: $1.05 \mathrm{~g}$ (99\%); yellow amorphous powder; $\mathrm{R}_{\mathrm{f}}($ EtOAc:Hex $=1: 2)=0.16 ;{ }^{1} \mathrm{H} \mathrm{NMR}\left(400 \mathrm{MHz}, \mathrm{CDCl}_{3}\right.$, $\left.25{ }^{\circ} \mathrm{C}, \mathrm{TMS}\right): \delta=8.30\left(\mathrm{~d}, J=1.8 \mathrm{~Hz}, 1 \mathrm{H}, \mathrm{Ar}-H_{7}\right), 8.00\left(\mathrm{dd}, J_{1}=8.5 \mathrm{~Hz}, J_{2}=1.8 \mathrm{~Hz}, 1 \mathrm{H}\right.$, $\left.\mathrm{Ar}-\mathrm{H}_{5}\right), 7.51\left(\mathrm{~d}, \mathrm{~J}=8.5 \mathrm{~Hz}, 1 \mathrm{H}, \mathrm{Ar}-\mathrm{H}_{4}\right), 4.52-4.44(\mathrm{~m}, 1 \mathrm{H}, \mathrm{CH}-\mathrm{NH}-\mathrm{CO}), 4.37$ (q, J = 7.1 Hz, $\left.2 \mathrm{H}, \mathrm{COO}-\mathrm{CH}_{2}-\mathrm{CH}_{3}\right), 4.19-4.10(\mathrm{~m}, 2 \mathrm{H}, 2 \times$ piperidine- $H), 3.82-3.70(\mathrm{~m}, 1 \mathrm{H}$, piperidine- $H)$, 3.34-3.24 (m, 2H, $2 \times$ piperidine- $H), 2.14-2.06(\mathrm{~m}, 2 \mathrm{H}, 2 \times$ piperidine- $H), 1.54-1.49(\mathrm{~m}, 2 \mathrm{H}$, $2 \times$ piperidine- $\mathrm{H}), 1.46\left(\mathrm{~s}, 9 \mathrm{H}, \mathrm{COC}\left(\mathrm{CH}_{3}\right)_{3}\right), 1.40 \mathrm{ppm}\left(\mathrm{t}, \mathrm{J}=7.1 \mathrm{~Hz}, 3 \mathrm{H}, \mathrm{COO}-\mathrm{CH}_{2}-\mathrm{CH}_{3}\right)$; LC-MS (ESI+): $m / z 406.3[\mathrm{M}+\mathrm{H}]+$ (calcd. $m / z=405.2$ for $\mathrm{C}_{20} \mathrm{H}_{27} \mathrm{~N}_{3} \mathrm{O}_{4} \mathrm{~S}$ ).

2-(4-(N-Boc-Amino)piperidin-1-yl)benzo[d]thiazole-6-carboxylic acid (12): Compound 11 $(1.00 \mathrm{~g}, 2.47 \mathrm{mmol})$ was suspended in ethanol $(96 \%, 50 \mathrm{~mL})$. Then, $2 \mathrm{M} \mathrm{NaOH}_{(\mathrm{aq})}(12.3 \mathrm{~mL}$, $24.6 \mathrm{mmol}$ ) was added. The mixture was heated to $100^{\circ} \mathrm{C}$ and left to stir for $1 \mathrm{~h}$. After that, the reaction mixture was cooled and acidified to $\mathrm{pH} 3$ using $2 \mathrm{M} \mathrm{HCl}_{(\mathrm{aq})}$. The precipitated product was then filtered off under pressure. Yield: $258 \mathrm{mg}(93 \%)$; yellow amorphous powder; $\mathrm{R}_{\mathrm{f}}(\mathrm{DCM}: \mathrm{MeOH}=9: 1)=0.34 ;{ }^{1} \mathrm{H} \mathrm{NMR}\left(400 \mathrm{MHz},\left[\mathrm{D}_{6}\right] \mathrm{DMSO}, 25{ }^{\circ} \mathrm{C}, \mathrm{TMS}\right)$ : $\delta=12.71(\mathrm{~s}, 1 \mathrm{H}, \mathrm{COOH}), 8.35\left(\mathrm{~d}, J=1.7 \mathrm{~Hz}, 1 \mathrm{H}, \mathrm{Ar}-H_{7}\right), 7.84\left(\mathrm{dd}, J_{1}=8.5 \mathrm{~Hz}, J_{2}=1.7 \mathrm{~Hz}\right.$, $\left.1 \mathrm{H}, \mathrm{Ar}-\mathrm{H}_{5}\right), 7.45\left(\mathrm{~d}, J=8.5 \mathrm{~Hz}, 1 \mathrm{H}, \mathrm{Ar}-\mathrm{H}_{4}\right), 6.94(\mathrm{~d}, J=7.9 \mathrm{~Hz}, 1 \mathrm{H}, \mathrm{CH}-\mathrm{NH}-\mathrm{CO}), 4.06-3.96(\mathrm{~m}$, $J=12.9 \mathrm{~Hz}, 2 \mathrm{H}, 2 \times$ piperidine- $H), 3.68-3.51(\mathrm{~m}, 1 \mathrm{H}, \mathrm{CH}-\mathrm{NH}), 1.86(\mathrm{~m}, 2 \mathrm{H}, 2 \times$ piperidine- $H)$, 1.50-1.33 ppm $\left(\mathrm{m}, 11 \mathrm{H}, 2 \times\right.$ piperidine- $\mathrm{H}$ and $\left.\mathrm{COC}\left(\mathrm{CH}_{3}\right)_{3}\right)$, not visible $(2 \times$ piperidine- $H)$; LC-MS (ESI+): $m / z 378.0[\mathrm{M}+\mathrm{H}]^{+}$(calcd. $m / z=377.1$ for $\mathrm{C}_{18} \mathrm{H}_{23} \mathrm{~N}_{3} \mathrm{O}_{4} \mathrm{~S}$ ).

The amide coupling procedure was used for the synthesis of 4-(N-Boc-amino)-1-(6-((3,4dichlorophenyl)carbamoyl)benzo[d]thiazol-2-yl)piperidine (13): Yield: $258 \mathrm{mg}$ (48\%); offwhite amorphous powder; $\mathrm{R}_{\mathrm{f}}($ EtOAc:Hex $=1: 2)=0.39 ;{ }^{1} \mathrm{H} \mathrm{NMR}\left(400 \mathrm{MHz},\left[\mathrm{D}_{6}\right] \mathrm{DMSO}\right.$, $\left.25^{\circ} \mathrm{C}, \mathrm{TMS}\right): \delta=10.31$ (s, $\left.1 \mathrm{H}, \mathrm{Ar}-\mathrm{NH}-\mathrm{COR}\right), 8.40$ (d, $\left.J=1.8 \mathrm{~Hz}, 1 \mathrm{H}, \mathrm{Ar}-H_{7}\right), 7.91\left(\mathrm{dd}, J_{1}=8.5\right.$, $\left.J_{2}=1.8 \mathrm{~Hz}, 1 \mathrm{H}, \mathrm{Ar}-H_{5}\right), 7.82(\mathrm{~d}, J=8.9 \mathrm{~Hz}, 2 \mathrm{H}, 2 \times \mathrm{Ar}-H), 7.55\left(\mathrm{~d}, J=8.5 \mathrm{~Hz}, 1 \mathrm{H}, \mathrm{Ar}-H_{4}\right)$, $7.41(\mathrm{~d}, J=8.9 \mathrm{~Hz}, 2 \mathrm{H}, 2 \times \mathrm{Ar}-\mathrm{H}), 3.69-3.58\left(\mathrm{~m}, 4 \mathrm{H}, 2 \times\right.$ piperazine- $\left.\mathrm{CH}_{2}\right), 3.54-3.46(\mathrm{~m}$, $4 \mathrm{H}, 2 \times$ piperazine- $\left.\mathrm{CH}_{2}\right), 1.43 \mathrm{ppm}\left(\mathrm{s}, 9 \mathrm{H}, \mathrm{COC}\left(\mathrm{CH}_{3}\right)_{3}\right) ; \mathrm{LC}-\mathrm{MS}(\mathrm{ESI}+): \mathrm{m} / z$ 473.1 [M+H] ${ }^{+}$ (calcd. $m / z=472.1$ for $\mathrm{C}_{23} \mathrm{H}_{25} \mathrm{ClN}_{4} \mathrm{O}_{3} \mathrm{~S}$ ).

The general procedure for the preparation of compounds $5 \mathrm{a}-\mathrm{m}$ was used for the synthesis of 4-amino-1-(6-((3,4-dichlorophenyl)carbamoyl)benzo[d]thiazol-2-yl)piperidine (14): Yield: $220 \mathrm{mg}(91 \%)$; off-white amorphous powder; $\mathrm{R}_{\mathrm{f}}(\mathrm{DCM}: \mathrm{MeOH}=9: 1)=0.02 ;{ }^{1} \mathrm{H}$ NMR (400 MHz, [D ${ }_{6}$ DMSO, $\left.25^{\circ} \mathrm{C}, \mathrm{TMS}\right): \delta=10.47$ (s, 1H, Ar-NH-COR), 8.40 (d, J = 1.8 Hz, $\left.1 \mathrm{H}, \mathrm{Ar}-H_{7}\right), 8.19\left(\mathrm{~d}, J=2.4 \mathrm{~Hz}, 1 \mathrm{H}, \mathrm{Ar}-H_{20}\right), 7.91\left(\mathrm{dd}, J_{1}=8.5, J_{2}=1.8 \mathrm{~Hz}, 1 \mathrm{H}, \mathrm{Ar}-H_{5}\right), 7.79$ $\left(\mathrm{dd}, J=8.9,2.4 \mathrm{~Hz}, 1 \mathrm{H}, \mathrm{Ar}-H_{24}\right), 7.61\left(\mathrm{~d}, J=8.9 \mathrm{~Hz}, 1 \mathrm{H}, \mathrm{Ar}-H_{23}\right), 7.50(\mathrm{~d}, J=8.5 \mathrm{~Hz}, 1 \mathrm{H}$, Ar- $\left.H_{4}\right), 3.99\left(\mathrm{~d}, \mathrm{~J}=13.2 \mathrm{~Hz}, 2 \mathrm{H}, \mathrm{CH}-\mathrm{NH}_{2}\right), 3.33-3.20(\mathrm{~m}, 2 \mathrm{H}, 2 \times$ piperidin- $H)$ 2.91-2.83 $\left(\mathrm{m}, 1 \mathrm{H}, \mathrm{CH}-\mathrm{NH}_{2}\right), 1.88-1.78(\mathrm{~m}, 2 \mathrm{H}, 2 \times$ piperidin- $H), 1.88-1.58(\mathrm{~m}, 4 \mathrm{H}, 4 \times$ piperidin- $H)$, 1.37-1.25 ppm (m, 2H, $2 \times$ piperidin- $H) ;{ }^{13} \mathrm{C}\left(101 \mathrm{MHz},\left[\mathrm{D}_{6}\right] \mathrm{DMSO}, 25{ }^{\circ} \mathrm{C}, \mathrm{TMS}\right): \delta=170.2$, $165.8,156.3,140.2,131.2,130.9$ (2C), 126.9, 126.8, 125.2, 121.8 (2C), 120.7, 117.9, 48.0 (2C), 47.6 (2C), 34.8 ppm; HRMS (ESI+) $m / z$ calcd. for $\mathrm{C}_{19} \mathrm{H}_{18} \mathrm{Cl}_{2} \mathrm{~N}_{4} \mathrm{OS}+\mathrm{H}^{+}: 421.0651[M+\mathrm{H}]^{+}$: found $421.0645 ; \mathrm{HPLC}: \mathrm{t}_{\mathrm{r}}=6.31 \mathrm{~min}(95.1 \%$ at $254 \mathrm{~nm})$. 


\section{References}

1. Sreedhar, A.S.; Kalmár, E.; Csermely, P.; Shen, Y.-F. Hsp90 Isoforms: Functions, Expression and Clinical Importance. FEBS Lett. 2004, 562, 11-15. [CrossRef]

2. Hoter, A.; El-Sabban, M.E.; Naim, H.Y. The HSP90 Family: Structure, Regulation, Function, and Implications in Health and Disease. Int. J. Mol. Sci. 2018, 19, 2560. [CrossRef]

3. Johnson, J.L. Evolution and Function of Diverse Hsp90 Homologs and Cochaperone Proteins. Biochim. Biophys. Acta Mol. Cell Res. 2012, 1823, 607-613. [CrossRef]

4. Wandinger, S.K.; Richter, K.; Buchner, J. The Hsp90 Chaperone Machinery. J. Biol. Chem. 2008, 283, 18473-18477. [CrossRef]

5. Jackson, S.E. Hsp90: Structure and function. In Molecular Chaperones; Jackson, S., Ed.; Springer: Berlin/Heidelberg, Germany, 2013; pp. 155-240.

6. Miyata, Y.; Nakamoto, H.; Neckers, L. The Therapeutic Target Hsp90 and Cancer Hallmarks. Curr. Pharm. Des. 2013, 19, 347-365. [CrossRef]

7. Söti, C.; Rácz, A.; Csermely, P. A Nucleotide-Dependent Molecular Switch Controls ATP Binding at the C-Terminal Domain of Hsp90: N-Terminal Nucleotide Binding Unmasks a C-Terminal Binding Pocket. J. Biol. Chem. 2002, 277, 7066-7075. [CrossRef]

8. Garnier, C.; Lafitte, D.; Tsvetkov, P.O.; Barbier, P.; Leclerc-Devin, J.; Millot, J.-M.; Briand, C.; Makarov, A.A.; Catelli, M.G.; Peyrot, V. Binding of ATP to Heat Shock Protein 90: Evidence for an ATP-Binding Site in the C-Terminal Domain. J. Biol. Chem. 2002, 277, 12208-12214. [CrossRef] [PubMed]

9. Daturpalli, S.; Waudby, C.A.; Meehan, S.; Jackson, S.E. Hsp90 Inhibits $\alpha$-Synuclein Aggregation by Interacting with Soluble Oligomers. J. Mol. Biol. 2013, 425, 4614-4628. [CrossRef] [PubMed]

10. Miyata, Y.; Yahara, I. The 90-KDa Heat Shock Protein, HSP90, Binds and Protects Casein Kinase II from Self-Aggregation and Enhances Its Kinase Activity. J. Biol. Chem. 1992, 267, 7042-7047. [CrossRef]

11. Whitesell, L.; Lindquist, S.L. HSP90 and the Chaperoning of Cancer. Nat. Rev. Cancer 2005, 5, 761-772. [CrossRef] [PubMed]

12. Sanchez, J.; Carter, T.R.; Cohen, M.S.; Blagg, B.S. Old and New Approaches to Target the Hsp90 Chaperone. Curr. Cancer Drug Targets 2020, 20, 253-270. [CrossRef]

13. Jaeger, A.M.; Whitesell, L. HSP90: Enabler of Cancer Adaptation. Annu. Rev. Cancer Biol. 2019, 3, 275-297. [CrossRef]

14. Jarosz, D.F.; Lindquist, S. Hsp90 and Environmental Stress Transform the Adaptive Value of Natural Genetic Variation. Science 2010, 330, 1820-1824. [CrossRef]

15. McDowell, C.L.; Sutton, R.B.; Obermann, W.M.J. Expression of Hsp90 Chaperome Proteins in Human Tumor Tissue. Int. J. Biol. Macromol. 2009, 45, 310-314. [CrossRef]

16. Schopf, F.H.; Biebl, M.M.; Buchner, J. The HSP90 Chaperone Machinery. Nat. Rev. Mol. Cell Biol. 2017, 18, 345-360. [CrossRef] [PubMed]

17. Ciocca, D.R.; Arrigo, A.P.; Calderwood, S.K. Heat Shock Proteins and Heat Shock Factor 1 in Carcinogenesis and Tumor Development: An Update. Arch. Toxicol. 2013, 87, 19-48. [CrossRef] [PubMed]

18. Trepel, J.; Mollapour, M.; Giaccone, G.; Neckers, L. Targeting the Dynamic HSP90 Complex in Cancer. Nat. Rev. Cancer 2010, 10, 537-549. [CrossRef] [PubMed]

19. Whitesell, L.; Mimnaugh, E.G.; De Costa, B.; Myers, C.E.; Neckers, L.M. Inhibition of Heat Shock Protein HSP90-Pp60v-Src Heteroprotein Complex Formation by Benzoquinone Ansamycins: Essential Role for Stress Proteins in Oncogenic Transformation. Proc. Natl. Acad. Sci. USA 1994, 91, 8324-8328. [CrossRef]

20. Goetz, M.P.; Toft, D.O.; Ames, M.M.; Erlichman, C. The Hsp90 Chaperone Complex as a Novel Target for Cancer Therapy. Ann. Oncol. 2003, 14, 1169-1176. [CrossRef] [PubMed]

21. Yuno, A.; Lee, M.-J.; Lee, S.; Tomita, Y.; Rekhtman, D.; Moore, B.; Trepel, J.B. Clinical evaluation and biomarker profiling of Hsp90 inhibitors. Methods Mol. Biol. 2018, 1709, 423-441.

22. Butler, L.M.; Ferraldeschi, R.; Armstrong, H.K.; Centenera, M.M.; Workman, P. Maximizing the Therapeutic Potential of Hsp90 Inhibitors. Mol. Cancer Res. 2015, 13, 1445-1451. [CrossRef]

23. Chatterjee, S.; Burns, T.F. Targeting Heat Shock Proteins in Cancer: A Promising Therapeutic Approach. Int. J. Mol. Sci. 2017, 18, 1978. [CrossRef] [PubMed]

24. Serwetnyk, M.A.; Blagg, B.S.J. The Disruption of Protein-protein Interactions with Co-Chaperones and Client Substrates as a Strategy towards Hsp90 Inhibition. Acta Pharm. Sin. B 2021, 11, 1446-1468. [CrossRef] [PubMed]

25. Donnelly, A.; Blagg, B.S.J. Novobiocin and Additional Inhibitors of the Hsp90 C-Terminal Nucleotide-Binding Pocket. Curr. Med. Chem. 2008, 15, 2702-2717. [CrossRef] [PubMed]

26. Allan, R.K.; Mok, D.; Ward, B.K.; Ratajczak, T. Modulation of Chaperone Function and Cochaperone Interaction by Novobiocin in the C-Terminal Domain of Hsp90: Evidence That Coumarin Antibiotics Disrupt Hsp90 Dimerization. J. Biol. Chem. 2006, 281, 7161-7171. [CrossRef] [PubMed]

27. Laurin, P.; Ferroud, D.; Schio, L.; Klich, M.; Dupuis-Hamelin, C.; Mauvais, P.; Lassaigne, P.; Bonnefoy, A.; Musicki, B. StructureActivity Relationship in Two Series of Aminoalkyl Substituted Coumarin Inhibitors of Gyrase B. Bioorg. Med. Chem. Lett. 1999, 9, 2875-2880. [CrossRef]

28. Zhao, J.; Zhao, H.; Hall, J.A.; Brown, D.; Brandes, E.; Bazzill, J.; Grogan, P.T.; Subramanian, C.; Vielhauer, G.; Cohen, M.S.; et al. Triazole Containing Novobiocin and Biphenyl Amides as Hsp90 C-Terminal Inhibitors. Med. Chem. Commun. 2014, 5, 1317-1323. [CrossRef] 
29. Garg, G.; Zhao, H.; Blagg, B.S.J. Design, Synthesis and Biological Evaluation of Alkylamino Biphenylamides as Hsp90 C-Terminal Inhibitors. Bioorg. Med. Chem. 2017, 25, 451-457. [CrossRef]

30. Moroni, E.; Zhao, H.; Blagg, B.S.J.; Colombo, G. Exploiting Conformational Dynamics in Drug Discovery: Design of C-Terminal Inhibitors of Hsp90 with Improved Activities. J. Chem. Inf. Model. 2014, 54, 195-208. [CrossRef] [PubMed]

31. Byrd, K.M.; Kent, C.N.; Blagg, B.S.J. Synthesis and Biological Evaluation of Stilbene Analogues as Hsp90 C-Terminal Inhibitors. ChemMedChem 2017, 12, 2022-2029. [CrossRef]

32. Tomašič, T.; Durcik, M.; Keegan, B.M.; Skledar, D.G.; Zajec, Ž.; Blagg, B.S.J.; Bryant, S.D. Discovery of Novel Hsp90 C-Terminal Inhibitors Using 3D-Pharmacophores Derived from Molecular Dynamics Simulations. Int. J. Mol. Sci. 2020, 21, 6898. [CrossRef]

33. Byrd, K.M.; Subramanian, C.; Sanchez, J.; Motiwala, H.F.; Liu, W.; Cohen, M.S.; Holzbeierlein, J.; Blagg, B.S.J. Synthesis and Biological Evaluation of Novobiocin Core Analogues as Hsp90 Inhibitors. Chemistry 2016, 22, 6921-6931. [CrossRef]

34. Lamut, A.; Gjorgjieva, M.; Naesens, L.; Liekens, S.; Lillsunde, K.-E.; Tammela, P.; Kikelj, D.; Tomašič, T. Anti-Influenza Virus Activity of Benzo[d]Thiazoles That Target Heat Shock Protein 90. Bioorg. Chem. 2020, 98, 103733. [CrossRef]

35. Pugh, K.W.; Zhang, Z.; Wang, J.; Xu, X.; Munthali, V.; Zuo, A.; Blagg, B.S.J. From Bacteria to Cancer: A Benzothiazole-Based DNA Gyrase B Inhibitor Redesigned for Hsp90 C-Terminal Inhibition. ACS Med. Chem. Lett. 2020, 11, 1535-1538. [CrossRef]

36. McGann, M. FRED and HYBRID Docking Performance on Standardized Datasets. J. Comput. Aided Mol. Des. 2012, 26, 897-906. [CrossRef] [PubMed]

37. McGann, M. FRED Pose Prediction and Virtual Screening Accuracy. J. Chem. Inf. Model. 2011, 51, 578-596. [CrossRef] [PubMed]

38. Verba, K.A.; Wang, R.Y.-R.; Arakawa, A.; Liu, Y.; Shirouzu, M.; Yokoyama, S.; Agard, D.A. Atomic Structure of Hsp90-Cdc37-Cdk4 Reveals That Hsp90 Traps and Stabilizes an Unfolded Kinase. Science 2016, 352, 1542-1547. [CrossRef] [PubMed]

39. Phillips, J.C.; Braun, R.; Wang, W.; Gumbart, J.; Tajkhorshid, E.; Villa, E.; Chipot, C.; Skeel, R.D.; Kalé, L.; Schulten, K. Scalable Molecular Dynamics with NAMD. J. Comput. Chem. 2005, 26, 1781-1802. [CrossRef]

40. Mackerell, A.D.; Feig, M.; Brooks, C.L. Extending the Treatment of Backbone Energetics in Protein Force Fields: Limitations of Gas-Phase Quantum Mechanics in Reproducing Protein Conformational Distributions in Molecular Dynamics Simulations. J. Comput. Chem. 2004, 25, 1400-1415. [CrossRef]

41. MacKerell, A.D.; Bashford, D.; Bellott, M.; Dunbrack, R.L.; Evanseck, J.D.; Field, M.J.; Fischer, S.; Gao, J.; Guo, H.; Ha, S.; et al. All-Atom Empirical Potential for Molecular Modeling and Dynamics Studies of Proteins. J. Phys. Chem. B 1998, 102, 3586-3616. [CrossRef]

42. Vanommeslaeghe, K.; Hatcher, E.; Acharya, C.; Kundu, S.; Zhong, S.; Shim, J.; Darian, E.; Guvench, O.; Lopes, P.; Vorobyov, I.; et al. CHARMM General Force Field: A Force Field for Drug-like Molecules Compatible with the CHARMM All-Atom Additive Biological Force Fields. J. Comput. Chem. 2010, 31, 671-690. [CrossRef] [PubMed]

43. Vanommeslaeghe, K.; Raman, E.P.; MacKerell, A.D. Automation of the CHARMM General Force Field (CGenFF) II: Assignment of Bonded Parameters and Partial Atomic Charges. J. Chem. Inf. Model. 2012, 52, 3155-3168. [CrossRef] [PubMed]

44. Vanommeslaeghe, K.; MacKerell, A.D. Automation of the CHARMM General Force Field (CGenFF) I: Bond Perception and Atom Typing. J. Chem. Inf. Model. 2012, 52, 3144-3154. [CrossRef] [PubMed]

45. Humphrey, W.; Dalke, A.; Schulten, K. VMD: Visual Molecular Dynamics. J. Mol. Graph. 1996, 14, 33-38. [CrossRef]

46. Essmann, U.; Perera, L.; Berkowitz, M.L.; Darden, T.; Lee, H.; Pedersen, L.G. A Smooth Particle Mesh Ewald Method. J. Chem. Phys. 1995, 103, 8577-8593. [CrossRef]

47. Ryckaert, J.-P.; Ciccotti, G.; Berendsen, H.J.C. Numerical Integration of the Cartesian Equations of Motion of a System with Constraints: Molecular Dynamics of n-Alkanes. J. Comput. Phys. 1977, 23, 327-341. [CrossRef]

48. Wolber, G.; Langer, T. LigandScout: 3-D Pharmacophores Derived from Protein-Bound Ligands and Their Use as Virtual Screening Filters. J. Chem. Inf. Model. 2005, 45, 160-169. [CrossRef]

49. Wilcken, R.; Zimmermann, M.O.; Lange, A.; Joerger, A.C.; Boeckler, F.M. Principles and Applications of Halogen Bonding in Medicinal Chemistry and Chemical Biology. J. Med. Chem. 2013, 56, 1363-1388. [CrossRef]

50. Goode, K.M.; Petrov, D.P.; Vickman, R.E.; Crist, S.A.; Pascuzzi, P.E.; Ratliff, T.L.; Jo Davisson, V.; Hazbun, T.R. Targeting the Hsp90 C-terminal domain to induce allosteric inhibition and selective client degradation. Biochim. Biophys. Acta Gen. Subj. 2017, 1861, 1992-2006. [CrossRef]

51. Kumar MV, V.; Noor, R.E.; Davis, R.E.; Zhang, Z.; Sipavicius, E.; Keramisanou, D.; Blagg, B.S.J.; Gelis, I. Molecular insights into the interaction of Hsp90 with allosteric inhibitors targeting the C-terminal domain. Med. Chem. Commun. 2018, 9, 1323-1331. [CrossRef] [PubMed]

52. Bhatia, S.; Diedrich, D.; Frieg, B.; Ahlert, H.; Stein, S.; Bopp, B.; Lang, F.; Zang, T.; Kröger, T.; Ernst, T.; et al. Targeting Hsp90 Dimerization via the $C$ terminus is effective in imatinib-resistant CML and lacks the heat shock response. Blood 2018, 132, 307-320. [CrossRef] [PubMed] 